\title{
Evolutionary/Advanced Light Water Reactor Data Report
}

Prepared for the

U. S. Department of Energy

Fissile Materials Control and Disposition Program

To Support the

Programmatic Environmental Impact Statement
RECFIVED

MAY 171996

OSTI

\section{Prepared by}

Fissile Material Dispositon Project Lawerence Livermore National Laboratory University of California/Livermore, California

Fissile Materials Disposition Program Reactor-Based Technologies Facility Project

Oak Ridge National Laboratory

Oak Ridge, Tennessee

February 9, 1996

is an informal report intended primanily for internal or limited external ribution. The opinions and conclusions stated are those of the author and or may not be those of the Laboratory.

$k$ performed under the auspices of the U.S. Department of Transportation and Department of Energy by the Lawrence Livermore National Laboratory under ract W-740S-Eng-48. 


\section{DISCLAIMER}

This document was prepared as an acoount of work sponsored by an agency of the United States Government. Neither the United States Government nor the University of California nor any of their employees, makes any warranty, express or implied, or assumes any legal liability or responsibility for the accuracy, completeness, or usefuiness of any information, apparatus, product, or process disdosed, or represents that its use would not infringe privately owned rights. Reference herein to any specific commercial product, process, or service by trade name, trademark, manufacturer, or otherwise, does not necessarily constitute or imply its endorsement, recommendation, or favoring by the United States Government or the University of California. The views and opinions of authors expressed herein do not necessarily state or reflect those of the United States Covernment or the University of California, and shall not be used for advertising or product endorsement purposes.

This report has been reproduced directly from the best available copy.

Available to DOE and DOE contractors from the Office of Scientific and Technical Information P.O. Box 62, Oak Ridge, TN 37831

Prices available from (615) 576-8401, FTS 626-8401

Available to the public from the

National Technical Information Service

U.S. Department of Commerce

5285 Port Royal Rd.,

Springfield, VA 22161 


\section{DISCLAMMER}

Portions of this document may be illegible in electronic image products. Images are produced from the best available original document. 


\title{
Evolutionary/Advanced Light Water Reactor Data Report
}

\author{
Prepared for the \\ U.S. Department of Energy \\ Fissile Materials Control and Disposition Program \\ To Support the \\ Programmatic Environmental Impact Statement

\section{Prepared by} \\ Fissile Material Disposition Project \\ Lawrence Livermore National Laboratory \\ University of California / Livermore, California \\ Fissile Materials Disposition Program \\ Reactor-Based Technologies Facility Project \\ Oak Ridge National Laboratory \\ Oak Ridge, Tennessee
}

February 9, 1996 
$1^{\prime}$ 


\section{TABLE OF CONTENTS}

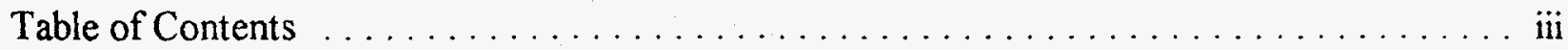

List of Figures $\ldots \ldots \ldots \ldots \ldots \ldots \ldots \ldots \ldots \ldots \ldots \ldots \ldots \ldots \ldots \ldots \ldots$ vii

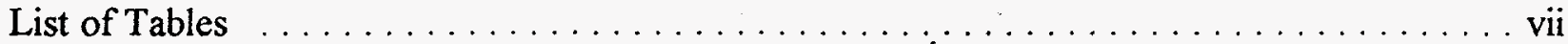

Executive Summary $\ldots \ldots \ldots \ldots \ldots \ldots \ldots \ldots \ldots \ldots \ldots \ldots \ldots \ldots \ldots$

1.0 ADVANCED LIGHT WATER REACTOR (LARGE AND SMALL) MISSION AND

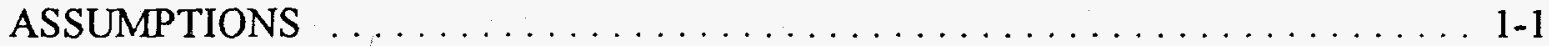

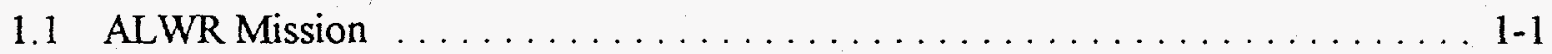

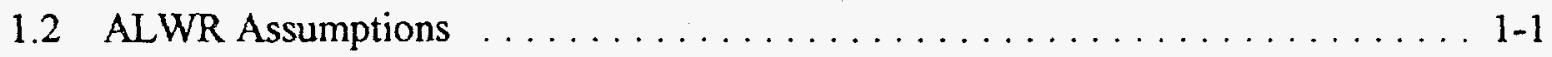

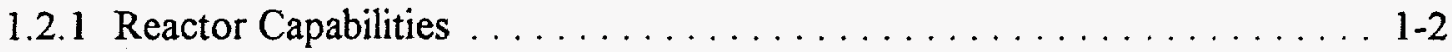

1.2.1.1 General Capabilities ........................

1.2.1.2 Electric Generation . . . . . . . . . . . . . . . . . .

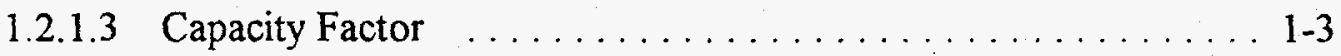

1.2.1.4 Spent Fuel $\ldots \ldots \ldots \ldots \ldots \ldots \ldots \ldots \ldots \ldots \ldots \ldots \ldots \ldots . . .3$

1.2.2 Reactor Facility Operating Basis $\ldots \ldots \ldots \ldots \ldots \ldots \ldots .1-6$

1.2.3 Compliance .............................. 1-7

1.2.3.1 Rules, Regulations, Codes, and Guidelines . . . . . . . . 1-7

1.2.3.2 Safeguards and Security ..................... 1-12

1.2.3.3 Environment, Safety, and Health . . . . . . . . . . . 1-13

1.2.3.3.1 Environment . . . . . . . . . . . . . . . . . . 1-13

1.2.3.3.2 Safety $\ldots \ldots \ldots \ldots \ldots \ldots \ldots \ldots \ldots \ldots \ldots \ldots \ldots \ldots \ldots \ldots \ldots \ldots, 1-13$

1.2.3.3.3 Health .............................. 1-13

1.2.3.4 Buffer Zones .............................. 1-14

1.2.3.5 Decontamination and Decommissioning ............. 1-14

1.2.3.6 Non-Safety/Safety Class . . . . . . . . . . . . . . . . . . . 1-14

1.2.3.7 Toxicological/Radiological Exposure ............. 1-14

1.2.3.7.1 Management of Toxic and Hazardous Materials . . . . . . . . 1-14

1.2.3.7.2 Radiation Protection ... . . . . . . . . . . . . . . . . . 1-14

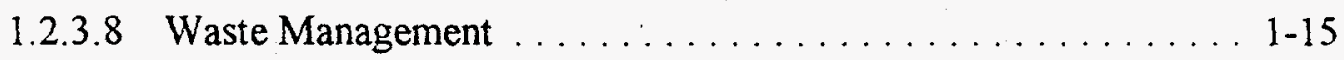

2.0 ADVANCED (EVOLUTIONARY) LIGHT WATER REACTOR DESCRIPTION ... 2-1

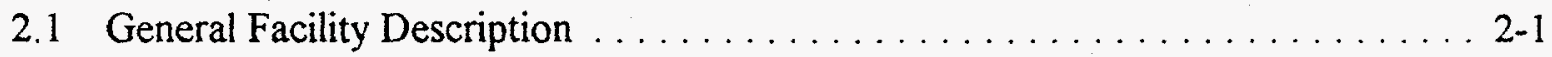

2.1.1 Functional Description ......................... 2-1

2.1 .2 Plot Plan ............................... 2-2

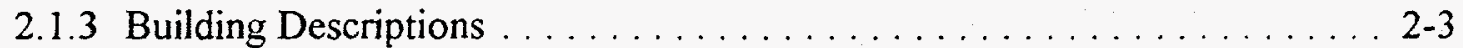

2.2 Design Safety . . . . . . . . . . . . . . . . . . . . . . . . .

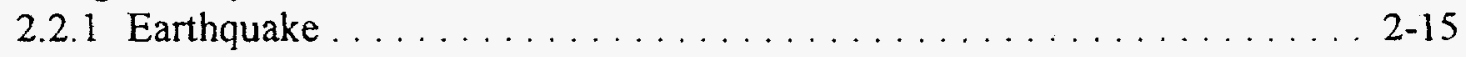

2.2.1.1 Seismic loading specification $\ldots \ldots \ldots \ldots \ldots \ldots \ldots \ldots . \ldots \ldots$

2.2.1.2 Design procedures for seismic responses evaluation . . . . . 2-16

2.2.1.3 Design detailing .......................... 2-17

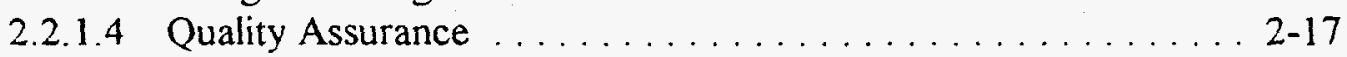


2.2 .2 Wind $\ldots \ldots \ldots \ldots \ldots \ldots \ldots \ldots \ldots \ldots \ldots \ldots \ldots \ldots \ldots \ldots \ldots \ldots \ldots \ldots \ldots \ldots \ldots .17$

2.2.2.1 Wind loading specification $\ldots \ldots \ldots \ldots \ldots \ldots \ldots \ldots \ldots \ldots \ldots \ldots \ldots \ldots$

2.2.2.2 Design procedures for wind responses evaluation . . . . . 2-18

2.2.2.3 Design detailing . . . . . . . . . . . . . . . . . . . 2-19

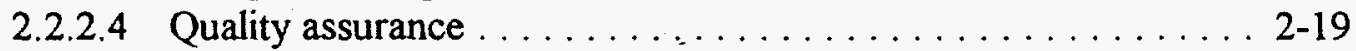

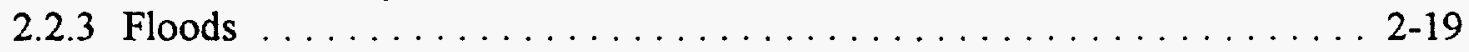

2.2.3.1 Flood loading specification $\ldots \ldots \ldots \ldots \ldots \ldots \ldots \ldots .2-19$

2.2.3.2 Design procedures for flood responses evaluation $\ldots \ldots \ldots .2-20$

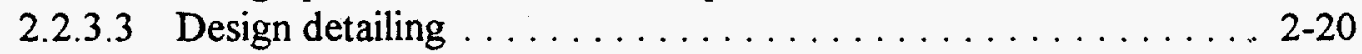

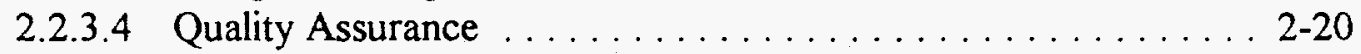

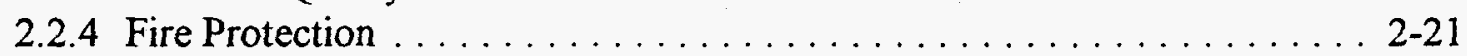

2.2.5 Safety Class Instrumentation and Control $\ldots \ldots \ldots \ldots \ldots \ldots \ldots .2-21$

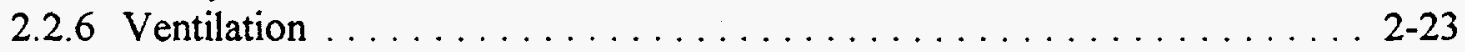

3.0 SITE MAP AND LAND USE REQUIREMENTS $\ldots \ldots \ldots \ldots \ldots \ldots \ldots \ldots \ldots .3-1$

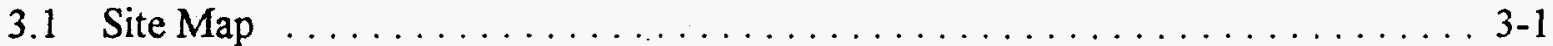

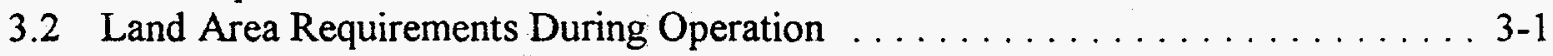

3.3 Land Area Requirements During Construction ................ 3-1

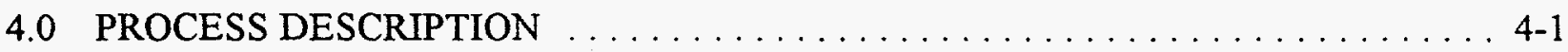

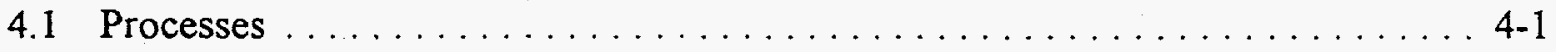

4.1 .1 Noble Gases ............................ 4-1

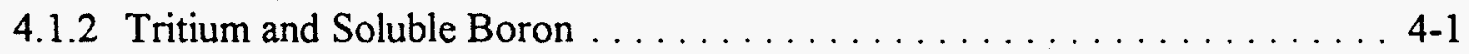

4.1 .3 Solid Wastes $\ldots \ldots \ldots \ldots \ldots \ldots \ldots \ldots \ldots \ldots \ldots \ldots \ldots, 4,2$

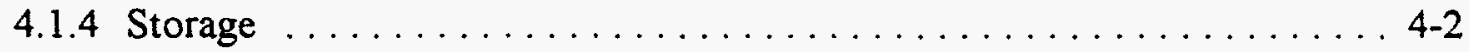

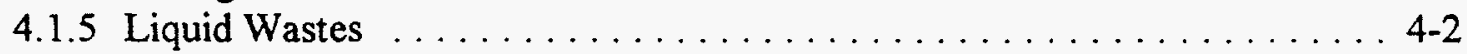

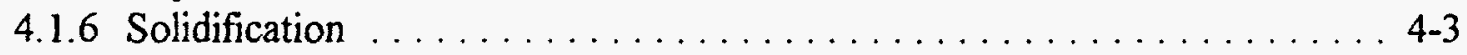

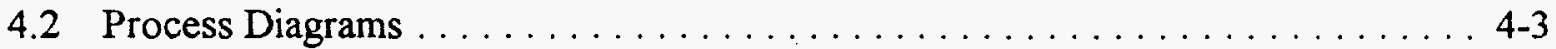

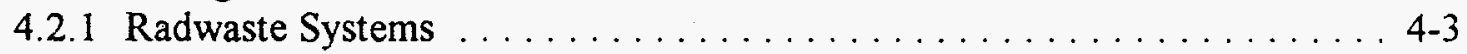

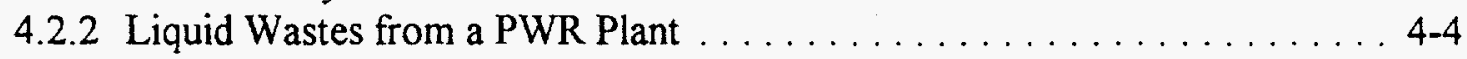

4.2.3 Gaseous Wastes from a PWR Plant $\ldots \ldots \ldots \ldots \ldots \ldots \ldots . \ldots .6 .6$

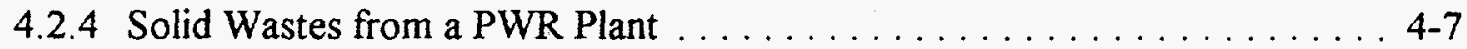

4.2.5 Tritium Disposal from a PWR Plant .................. 4-7

4.2.6 Comparison of PWR and BWR Wastes . . . . . . . . . . . . 4-8

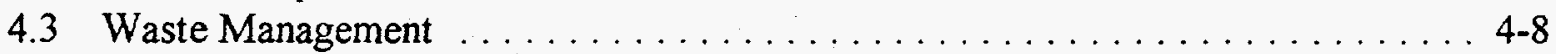

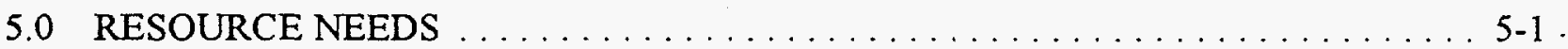

5.1 Materials/Resources Consumed During Operation $\ldots \ldots \ldots \ldots \ldots \ldots \ldots$ 5-1

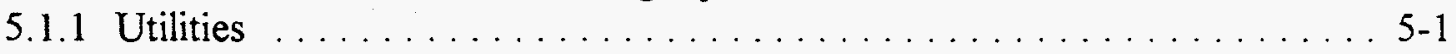

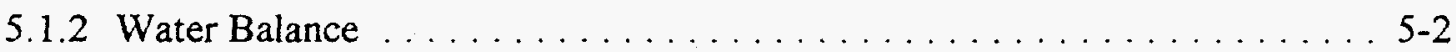

5.1 .3 Chemicals . . . . . . . . . . . . . . . . . . . . . . 5-7

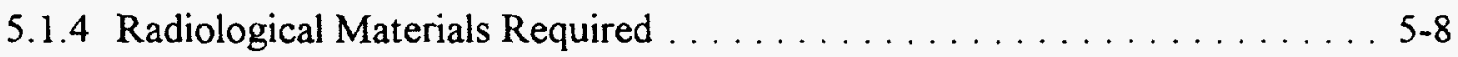

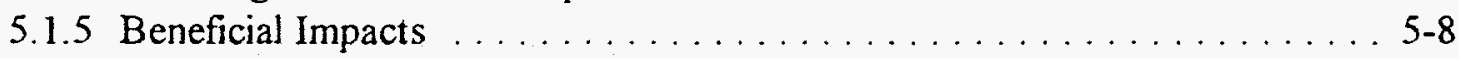

5.2 Material/Resources Consumed During Construction . . . . . . . . . . . 5-9 
6.0 EMPLOYMENT NEEDS . . . . . . . . . . . . . . . . . . . . . . 6-1

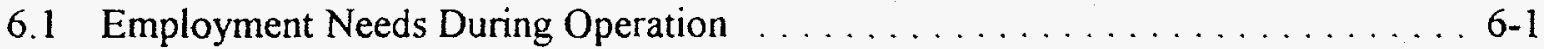

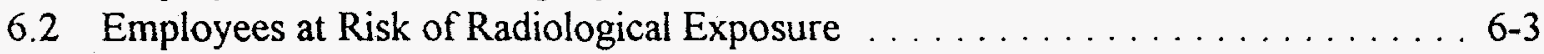

6.3 Employment Needs During Construction $\ldots \ldots \ldots \ldots \ldots \ldots \ldots . \ldots .6 .6 . \ldots$

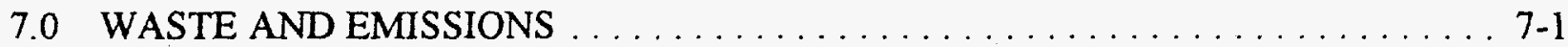

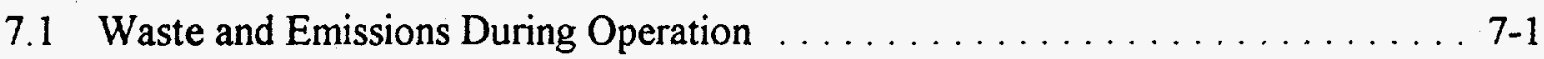

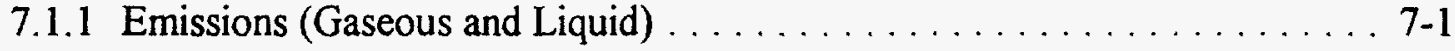

7.1.1.1 Emissions of Air Pollutants ................. 7-1

7.1.1.2 Liquid Emissions of Chemical Pollutants ........... 7-1

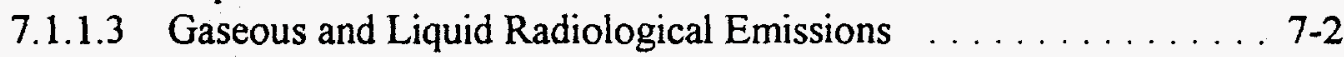

7.1.1.3.1 Radioactive Gaseous Effluents . . . . . . . . . . . . 7-2

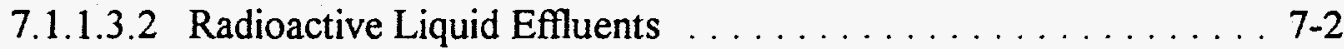

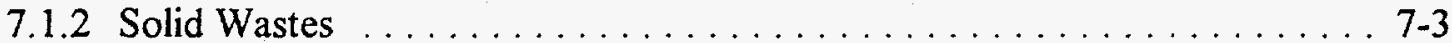

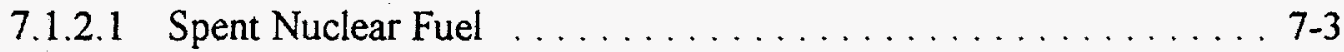

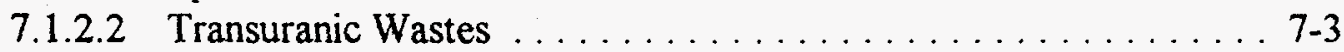

7.1.2.3 Low-Level Wastes ........................ . $7-3$

7.1.2.4 Mixed Transuranic Wastes . . . . . . . . . . . . . . . . . 7-4

7.1.2.5 Mixed Low-Level Wastes $\ldots \ldots \ldots \ldots \ldots \ldots \ldots \ldots \ldots . . . \ldots .4$

7.1.2.6 Hazardous Wastes . . . . . . . . . . . . . . . . . . . . 7-4

7.1.2.7 Nonhazardous (Sanitary) Wastes . . . . . . . . . . . . . . . .

7.1.2.8 Nonhazardous (Other) Wastes . . . . . . . . . . . . . 7-5

7.2 Waste and Emissions Generated During Construction . . . . . . . . . . 7-10

7.2 .1 Emissions . . . . . . . . . . . . . . . . . . . . . . . . . . . 7-10

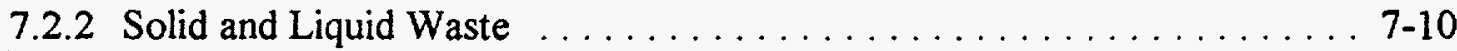

7.2.2.1 Radioactive Waste . . . . . . . . . . . . . . . . . . 7-10

7.2.2.2 Hazardous Waste . . . . . . . . . . . . . . . . . . . . . . 7-10

7.2.2.3 Nonhazardous Waste . . . . . . . . . . . . . . . . . 7-10

7.3 Avoided Environmental Impacts . . . . . . . . . . . . . . . .

8.0 Design Process for Accident Mitigation . . . . . . . . . . . . . . . . 8 8-1

8.1 Operational and Design Basis, and Beyond Design Basis Bounding Accidents . . 8-1

8.1.1 Operational and Design Basis Accidents . . . . . . . . . . . 8-2

8.1.1.1 Bounding design-basis accident for the large advanced reactor . . 8-2

8.1.1.2 Bounding design-basis accident for the small advanced reactor . . 8-3

8.1.2 Beyond Design Basis Accidents . . . . . . . . . . . . . . . . 8-3

8.1.2.1 Severe accident spectrum for the large advanced reactor . . . . 8 8-4

8.1.2.2 Severe accident spectrum for the small advanced reactor ..... 8-8 


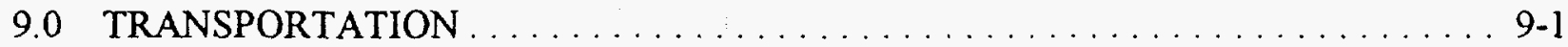

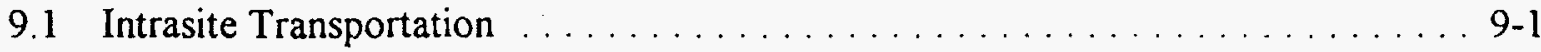

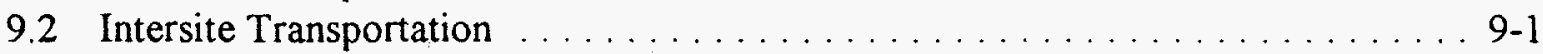

9.2 .1 Incoming Material . . . . . . . . . . . . . . . . . . . . .

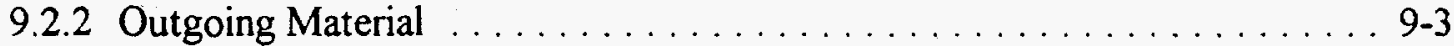

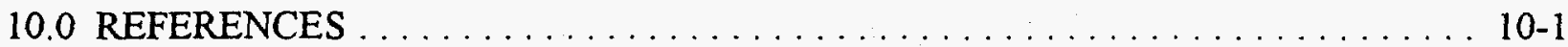

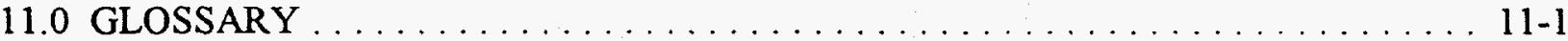




\section{FIGURES}

Figure 2-1 Advanced Boiling Water Reactor Assembly

Figure 2-2 Plant Cutaway - Advanced Boiling Water Reactor

Figure 2-3 Plant Cutaway - Combustion Engineering System 80+

Figure 2-4 Small ALWR Reactor Coolant Loop Isometric (PDR 600)

Figure 2-5a Facility Flow Diagram - Large ALWR

Figure 2-5b Facility Flow Diagram - Small ALWR

Figure 2-6 Conceptual View of ABWR Nuclear Island

Figure 2-7 Large PWR Nuclear Island - Elevation View

Figure 2-8 Large PWR Nuclear Island - Elevation View Rotated $90^{\circ}$

Figure 2-9 Large PWR Nuclear Island - General Arrangement

Figure 3-1 ALWR Conceptual Site Map - ABWR

Figure 3-2 ALWR Conceptual Site Map - Large PWR

Figure 3-3 ALWR Conceptual Site Map - Small PWR

Figure 4-1 Schematic Diagram of a Typical PWR Chemical and Volume Control System

Figure 4-2 Typical Liquid Radwaste System for a PWR

Figure 4-3 Schematic Outline of a PWR Gaseous Radwaste System

\section{TABLES}

Table 1-1 ALWR Option Characteristics

Table 1-2 Typical Regulatory and Environmental Permits and Licenses for ALWR Plutonium Disposition Facility

Table 2-1 General Building Descriptions - Large ALWR

Table 5-1 Utilities Consumed During Operation - Dry Site

Table 5-2 Utilities Consumed During Operation - Wet Site 
Table 5-3

Table 5-4

Table 6-1

Table 6-2

Table 7-I

Table 7-2

Table 7-3

Table 7-4

Table 7-5

Table 7-6

Table 8-1

Table 8-2

Table 8-3

Table 8-4

Table 8-5

Table 8-6

Table 9-1

Table 9-2
Annual Chemicals Consumed During Operation

Materials/Resources Consumed During Construction

Employment During Operation

Reactor Construction Employees Needed by Year

Annual Emissions During Operation

Annual Radiological Emissions During Operation

Annual Reactor Spent Fuel and Waste Volumes During Operation

Emissions During Peak Construction Year

Average Annual Wastes During Construction

Annual Avoided Environmental Impacts

Large Advanced Reactor Initial Core Inventory $\left(\mathrm{UO}_{2}\right.$ Fuel)

Small Advanced Reactor Initial Core Inventory $\left(\mathrm{UO}_{2}\right.$ Fuel)

Typical Core Inventory Isotopic Ratios: $\mathrm{MOX} / \mathrm{UO}_{2}$ Core

Estimated Design Basis Accident Releases for the Large and Small Advanced Reactor Designs $\left(\mathrm{UO}_{2}\right.$ Fuel)

Representative Release Class Frequencies and Release Fractions for the Large Advanced Reactor

Representative Release Class Frequencies and Release Fractions for the Small Advanced Reactor

Large ALWR Intersite Transportation Data

Small ALWR Intersite Transportation Data 


\section{EXECUTIVE SUMMARY}

The U.S. Department of Energy (DOE), Office of Fissile Material Disposition, is examining options for placing fissile materials that were produced for fabrication of weapons, and now are deemed to be surplus, into a condition that is substantially irreversible and makes its use in weapons inherently more difficult. The principal fissile materials subject to this disposition activity are plutonium and uranium containing substantial fractions of plutonium-239 and uranium-235. The data in this report, prepared as technical input to the fissile material disposition Programmatic Environmental Impact Statement (PEIS) deal only with the disposition of plutonium that contains well over $80 \%$ plutonium-239. In fact, the data were developed on the basis of weapon-grade plutonium which contains, typically, $93.6 \%$ plutonium- 239 and $5.9 \%$ plutonium-240 as the principal isotopes.

One of the options for disposition of weapon-grade plutonium being considered is the power reactor alternative. Plutonium would be fabricated into mixed oxide (MOX) fuel and fissioned ("burned") in a reactor to produce electric power. The MOX fuel will contain dioxides of uranium and plutonium with less than $7 \%$ weapon-grade plutonium and uranium that has about $0.2 \%$ uranium-235. The disposition mission could, for example, be carried out in existing power reactors, of which there are over 100 in the United States.

Alternatively, new LWRs could be constructed especially for disposition of plutonium. These would be of the latest U.S. design(s) incorporating numerous design simplifications and safety enhancements. These "evolutionary" or "advanced" designs would offer not only technological advances, but also flexibility in siting and the option of either government- or private (e.g., utility ownership. The new reactor designs can accommodate somewhat higher plutonium throughputs. This data report deals solely with the "evolutionary" LWR alternative. 


\subsection{ADVANCED LIGHT WATER REACTOR (LARGE AND SMALL) MISSION AND ASSUMPTIONS}

\subsection{ALWR Mission}

ALWRs will be constructed for the purpose of plutonium disposition and simultaneous production of electric power. Weapon-grade plutonium will be considered to be dispositioned after it is converted to reactor spent fuel that contains plutonium with an isotopic composition similar to that of spent fuel from commercial power reactors. Typically, this so-called reactorgrade plutonium contains less than $60 \%$ plutonium- 239 , more than $20 \%$ plutonium- 240 , and other troublesome (from a weapon design viewpoint) isotopes. Also, for a long period of time (over 100 years) the radiation from the spent fuel remains lethal at small distances (without shielding) even for short-duration exposures. It is considered difficult and extremely difficult, respectively, to separate the plutonium chemically from the spent fuel and isotopically to increase the fractional plutonium-239 content. While these activities could be performed by a national government, it is considered unlikely that they could be carried out clandestinely by a sub-national group.

A quantity of 50 metric tons (MT) of weapon-grade plutonium is to be dispositioned within 25 years from the start of the project. Electricity is to be produced over the life of the reactor (40 to 60 years). Variations in mission time are also considered.

\subsection{ALWR Assumptions}

The data provided below are based on the weapon-grade plutonium being delivered as MOX fuel assemblies to the site of one or more newly constructed light water reactors (LWRs) of new design. There would be no advantage to building reactors of older design, as the new designs offer even safer and less costly operation. Four ALWR designs by U.S. designers are considered: (1) an evolutionary 1300-MWe boiling water reactor (BWR), (2) an evolutionary 1250-MWe pressurized water reactor (PWR), (3) an evolutionary 1400-MWe PWR, and (4) an advanced $600-\mathrm{MWe}$ PWR. Each fuel assembly loaded into the reactor would reside there between 4 to 5.4 years during which time the reactor would be at power $75 \%$ of the time. After discharge from the reactor, the spent fuel assemblies would be stored at the reactor site for 3 to 10 years, at which time they would be shipped to a spent fuel repository for perpetuity. Eventually, the spent fuel will contain about $35 \mathrm{MT}$ of reactor-grade plutonium, since about $30 \%$ (net) of the plutonium will have been annihilated during reactor operation. This amount of reactor-grade plutonium may be considered in the context of the quantities of reactor-grade plutonium in spent fuel of about $300 \mathrm{MT}$ in the U.S. and $1000 \mathrm{MT}$ in the world that are expected to be generated by the year 2000 .

An aggressive schedule of construction is assumed, as there is considerable experience directly related to construction of the evolutionary/advanced reactor designs and their regulatory review processes have in general already begun. The three evolutionary and one advanced reactor designs considered below allow core loadings of all-MOX fuel.

The GE Nuclear Energy Advanced Boiling Water Reactor (ABWR) received final design approval from the Nuclear Regulatory Commission (NRC) in July 1994. Two of these plants, each to produce nominally $1300 \mathrm{MWe}$ (3925 MWt) using (LEU) fuel, are currently under construction in Japan. MOX fuel for the ABWR is designed to be interchangeable with its 
standard low-enriched uranium (LEU) fuel. This is achieved by minimizing the difference in reactivity as a function of burnup and on control blade worth while maintaining reasonable peakto-average power ratios. Data used in this report are taken from Ref. 1.

The ABB-Combustion Engineering evolutionary reactor design, the System $80+$, builds on simplifications and improvements applied to the System 80 design. The commercial version produces $1300 \mathrm{MWe}(3915 \mathrm{MWt}$ ). Final design approval was obtained from NRC also in July 1994. In order to provide the same thermal margins when converted to MOX fuel, the reactor thermal power is reduced to $3800 \mathrm{MW}$, thus reducing the net electric power to $1250 \mathrm{MW}$. Data used in this report are taken from Ref. 2.

Westinghouse Electric Corp. has designed a 1400-MWe PWR that meets U.S. evolutionary reactor criteria for the $1990 \mathrm{~s}$. The design was submitted for NRC review and a Preliminary Design Approval was issued in May 1991, however at present no regulatory activities are in progress in the U.S. with respect to this design. The Japanese Atomic Power Corporation plans to build two units at its Tsurga site that meet both Japanese and U.S. licensing criteria. The first plant is to start operation in 2001. For disposition of plutonium, Westinghouse would change the core design to utilize their conventional $17 \times 17$ fuel lattice. Westinghouse assigns the name PDR 1400 to this reactor (Plutonium Disposition Reactor). Data used in this report are taken from Ref. 3.

The commercial version of the advanced reactor design by Westinghouse Electric Corp. is known as the (Advanced Passive) AP600. These 1930-MWt reactors produce nominally $600 \mathrm{MWe}$. The standard safety analysis report and the probability risk assessment were submitted to the Nuclear Regulatory Commission (NRC) in June 1992. Final design approval by NRC is expected in September 1996. If it were decided to use the AP600, supplementary analyses would be submitted to NRC so that use of weapon-derived MOX fuel could be included in the resulting license for the redesignated PDR600. Data used in this report are taken from Ref. 3.

\subsubsection{Reactor Capabilities}

\subsubsection{General Capabilities}

Table 1-1 lists data generally taken from Refs. 1-3 that apply to the four new reactors that are considered in this data report. These data show the number of reactors required to disposition $50 \mathrm{MT}$ of weapon-grade plutonium in less than 25 years from project start, the nominal mission. Characteristics of the fresh and spent fuel are also given in Table 1-1. Spent fuel resulting from the plutonium disposition operation in the evolutionary/advanced reactors will contain between 34.5 and 38.5 MT of reactor-grade plutonium. Facilities are provided at the reactor to allow appropriate pool storage of spent fuel for 10 years after discharge. The time to process $50 \mathrm{MT}$ of plutonium (see Table 1-1) includes the time to construct and startup the reactors, and all reactor operations that include MOX fuel. During the latter period, the final recharge(s) would include transitional use of LEU fuel. After the MOX fuel is processed, the reactors would continue to operate on LEU fuel to the end of their design life. For the purpose of Table 1-1, their design life is assumed to be 40 years. During 40 years, the reactors would generate 2.6 to 3.3 times as much electricity as can be ascribed to the MOX fuel. Current thinking supports a design life capability of 60 years. 


\subsubsection{Electric Generation}

These reactors are intended to deliver electric power competitively to the U.S. power grid. Additional electricity generation will be required in the U.S. to meet the future demand of an increasing population. As indicated in Table 1-1, for the nominal mission to complete disposition in 25 years after project start, the annual U.S. electricity generation that would be derived from the reactor option is assumed to be 1.8 to $2.1 \mathrm{GWy}$. This amount of generation would add about $0.6 \%$ to the $329 \mathrm{GWy}$ generated by electric utilities in the U.S. in 1993 (derived from data given in Ref. 4). Between 1986 and 1993 total electric generation in the U.S. increased at an average annual rate of $2.5 \%$ (Ref. 5). Reference 6 projects (low case) that the annual electricity demand in the U.S. will be $384 \mathrm{GWy}$ in 2010 , representing a lower average annual growth of slightly above $1 \%$ over the time period 1990 to 2010 . This lower growth rate results from recent emphasis placed on energy efficiency. Conservatively however, it is clear that there is a demand for the electricity that the ALWRs would generate. From the standpoint of the future U.S. need to generate electricity, a more aggressive disposition schedule than called for in the nominal mission could be accommodated by building and operating more reactors than indicated in Table 1-1.

\subsubsection{Capacity Factor}

A capacity factor of 0.75 is assumed for the data in Table 1-1. This value may be compared with the average capacity factor for U.S. reactors of 0.71 in 1993, and the range of 0.97 to 1.01 for the ten highest capacity factors for U.S. reactors in 1993 (Ref. 4). Because the evolutionary reactors are greatly simplified, it is reasonable to assume that they will exhibit a capacity factor above the average factor for existing U.S. LWRs.

\subsubsection{Spent Fuel}

The isotopic data in Table 1-1 indicates that the four reactors produce similar spent fuel, and that the spent MOX fuel is also similar to spent LEU fuel. While the spent MOX fuel has slightly higher fractions of plutonium-239 and -240 than the spent LEU fuel, the ratios of the fractions for these isotopes are about the same, 2.4. A low plutonium-239/plutonium-240 ratio and a high plutonium-240 content is desirable as a deterrent to weapon use. Although the overall higher plutonium content, $\sim 5 \%$ in the spent MOX fuel versus $\sim 1 \%$ in spent LEU fuel, makes the spent MOX fuel assembly a more attractive target for theft, the radiation barrier for either type of fuel assembly is considered to be adequate. Safeguards are required even for spent LEU fuel and similar measures will apply to spent MOX fuel (see Section 2.3). 
Table 1-1 ALWR Option Characteristics

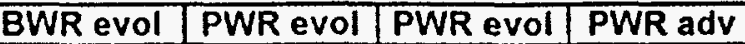
\begin{tabular}{|l|c|c|c|}
\hline ABWR & Syst 80+ & PDR1400 & PDR600 \\
\hline
\end{tabular}

Schedule relative to project start

Number of reactors

Time construction permit granted (mo)

Time operations start, for 1st reactor (mo)

Time operations start, for 2nd reactor ( $\mathrm{mo}$ )

Time operations start, for 3rd reactor $(\mathrm{mo})$

Time operations start, for 4th reactor (mo)

Time to process $50 \mathrm{MT}$ of $\mathrm{Pu}(\mathrm{v})$

\begin{tabular}{|c|c|c|c|c|}
\hline & 2 & 2 & 2 & 4 \\
\hline$(\mathrm{mo})$ & 27 & 18 & 60 & 54 \\
\hline$(\mathrm{mo})$ & 83 & 74 & 108 & 108 \\
\hline$(\mathrm{mo})$ & 92 & 98 & 120 & 114 \\
\hline$(\mathrm{mo})$ & & & & 120 \\
\hline
\end{tabular}

General performance

Capacity factor

Thermal power per reactor (MWth)

Net electric power per reactor (MWe)

Net plant efficiency (frac)

Net electrical energy ascribed to MOX fuel (GWy)

Net electrical energy during 40-y plant life (GWy)

Fraction of plutonium annihilated

\begin{tabular}{|l|c|c|c|c|}
\hline & 0.75 & 0.75 & 0.75 & 0.75 \\
\hline & 3926 & 3817 & 4100 & 1933 \\
\hline & 1300 & 1256 & 1400 & 600 \\
\hline OX fuel (GWy) & 0.331 & 0.329 & 0.341 & 0.310 \\
\hline ant life (GWy) & 29.5 & 28.3 & 25.7 & 23.1 \\
\hline & 78.0 & 75.4 & 84.0 & 72.0 \\
\hline
\end{tabular}

Fresh fuel characteristics

Reactor Pu inventory - first core (kg Pu)

Pu content (kg Pu/fuel assembly)

Fuel assembly mass (kg)

Fuel assembly length $(\mathrm{m})$

Fuel assembly width $(m)$

U mass (kg U/fuel assembly)

U-235 enrichment (kg U-235/kg U)

Number of fuel assemblies in core

Fraction of $\mathrm{Pu}$ in heavy metal (kg Pu/kg HM)

\begin{tabular}{|c|c|c|c|c|}
\hline & 6631 & 6670 & 7235 & 4081 \\
\hline & 7.6 & 27.7 & 28.1 & 28.1 \\
\hline & 303 & 664 & 686 & 686 \\
\hline & 4.6 & 3.8 & 4.4 & 4.4 \\
& 0.15 & 0.20 & 0.22 & 0.22 \\
\hline & 169 & 382 & 433 & 433 \\
\hline & 0.002 & 0.002 & 0.002 & 0.002 \\
\hline & 872 & 241 & 257 & 145 \\
\hline & 0.0432 & 0.0676 & 0.0610 & 0.0610 \\
\hline
\end{tabular}

Equilibrium cycle recharge

Fuel Pu content (kg Pu)

Fraction of Pu in heavy metal (kg Pu/kg HM)

Number of recharges (incl partial MOX)

Number of fuel assemblies discharged

Number of rods per fuel assembly

Cycle length (mo)

Average fraction of core removed at each discharge

\begin{tabular}{|c|c|c|c|c|}
\hline 2842 & 6670 & 2609 & 1472 \\
\hline 0.0576 & 0.0676 & 0.0660 & 0.0660 \\
\hline 13 & 6 & 14 & 23 \\
\hline 280 & 241 & 85.7 & 48.3 \\
\hline & 60 & 228 & 264 & 264 \\
\hline 21.5 & 48.0 & 16.9 & 20.0 \\
\hline & 0.32 & 1.00 & 0.33 & 0.33 \\
\hline
\end{tabular}

Fuel characteristics at discharge

Pu mass discharged per cycle (kg Pu)

Pu-238 fraction (kg Pu-238/kg Pu)

Pu-239 fraction (kg Pu-239/kg Pu)

$\mathrm{Pu}-240$ fraction $(\mathrm{kg} \mathrm{Pu}-240 / \mathrm{kg} \mathrm{Pu})$

Pu-241 fraction ( $\mathrm{kg}$ Pu-241/kg Pu)

Pu-242 fraction (kg Pu-242/kg Pu)

Heat generation in one fuel assembly (kW)

Gamma radiation (Sv/h at surface, midplane)

Burnup (MWd $/ \mathrm{kg} \mathrm{HM}$ )

Fraction of Pu in spent fuel (kg Pu/kg HM)

\begin{tabular}{|l|c|c|c|c|} 
& 1953 & 4859 & 1968 & 1101 \\
\hline & 0.0058 & & 0.0010 & 0.0010 \\
\hline & 0.590 & 0.631 & 0.621 & 0.621 \\
\hline & 0.270 & 0.227 & 0.242 & 0.242 \\
\hline & 0.105 & 0.126 & 0.118 & 0.118 \\
\hline & 0.028 & 0.017 & 0.018 & 0.018 \\
\hline $\mathrm{kW}$ & 18.0 & 59.8 & 36.1 & 36.1 \\
\hline & $2.0 \mathrm{E}+04$ & $7.9 \mathrm{E}+04$ & $2.0 \mathrm{E}+04$ & $2.0 \mathrm{E}+04$ \\
\hline $\mathrm{M})$ & 39.0 & 42.6 & 40.0 & 40.0 \\
\hline & 0.0412 & 0.0514 & 0.0510 & 0.0510 \\
\hline
\end{tabular}

ALWR PEIS Input, Rev. 0

$1-4$

February 9,1996 
Table 1-1 ALWR Option Characteristics (cont.)

\begin{tabular}{|c|c|c|c|}
\hline BWR evol & PWR evol & PWR evol & PWR adv \\
\hline ABWR & Syst 80+ & PDR1400 & PDR600 \\
\hline
\end{tabular}

Fuel characteristics at discharge (uranium fuel)

\begin{tabular}{|l|c|c|c|c|}
\hline 1) Pu mass discharged per cycle (kg Pu) & 411 & 390 & 375 & 375 \\
\hline 2) $\mathrm{Pu}-238$ fraction (kg Pu-238/kg Pu) & 0.0201 & 0.0180 & 0.0200 & 0.0200 \\
\hline 3) $\mathrm{Pu}-239$ fraction (kg Pu-239/kg Pu) & 0.552 & 0.527 & 0.540 & 0.540 \\
\hline 4) Pu-240 fraction (kg Pu-240/kg Pu) & 0.200 & 0.232 & 0.227 & 0.227 \\
\hline 5) Pu-241 fraction (kg Pu-241/kg Pu) & 0.163 & 0.154 & 0.151 & 0.151 \\
\hline 6) Pu-242 fraction (kg Pu-242/kg Pu) & 0.064 & 0.070 & 0.062 & 0.062 \\
\hline Heat generation in one fuel assembly (kW) & 19.5 & 55.7 & 36.0 & 36.0 \\
\hline Gamma radiation (Sv/h at surface, midplane) & $2.4 E+04$ & $8.7 \mathrm{E}+04$ & $2.0 \mathrm{E}+04$ & $2.0 \mathrm{E}+04$ \\
\hline Burnup (MWd/kg HM) & 39.0 & 47.8 & 44.0 & 44.0 \\
\hline Fraction of Pu in spent fuel (kg Pu/kg HM) & 0.0086 & 0.0102 & 0.0112 & 0.0112 \\
\hline Fraction of U-235 in spent fuel (kg U-235/kg HM) & 0.0100 & 0.0092 & 0.0104 & 0.0104 \\
\hline
\end{tabular}

Fuel characteristics 1 y after discharge

\begin{tabular}{|l|c|c|c|c|}
\hline Pu-238 fraction (kg Pu-238/kg Pu) & 0.0082 & 0.0034 & 0.0010 & 0.0010 \\
\hline Pu-239 fraction (kg Pu-239/kg Pu) & 0.592 & 0.610 & 0.624 & 0.624 \\
\hline Pu-240 fraction (kg Pu-240/kg Pu) & 0.271 & 0.238 & 0.244 & 0.244 \\
\hline Pu-241 fraction (kg Pu-241/kg Pu) & 0.100 & 0.129 & 0.113 & 0.113 \\
\hline Pu-242 fraction (kg Pu-242/kg Pu) & 0.029 & 0.020 & 0.018 & 0.018 \\
\hline Heat generation in one fuel assembly (kW) & 2.4 & 7.6 & 4.7 & 4.7 \\
\hline Gamma radiation (Sv/h at surface, midplane) & 1170 & 4991 & 1170 & 1170 \\
\hline
\end{tabular}

Fuel characteristics 10 y after discharge

Pu-238 fraction (kg Pu-238/kg Pu)

Pu-239 fraction (kg Pu-239/kg Pu)

Pu-240 fraction (kg Pu-240/kg Pu)

Pu-241 fraction (kg Pu-241/kg Pu)

$\mathrm{Pu}-242$ fraction ( $\mathrm{kg} \mathrm{Pu}-242 / \mathrm{kg} \mathrm{Pu}$ )

Heat generation in one fuel assembly (W)

Gamma radiation (Sv/h at surface, midplane)

\begin{tabular}{|c|c|c|c|c|}
\hline & 0.0086 & 0.0042 & 0.0010 & 0.0010 \\
\hline & 0.611 & 0.638 & 0.650 & 0.650 \\
\hline & 0.283 & 0.249 & 0.254 & 0.254 \\
\hline & 0.067 & 0.088 & 0.077 & 0.077 \\
\hline & 0.030 & 0.021 & 0.019 & 0.019 \\
\hline & 319 & 688 & 692 & 692 \\
\hline
\end{tabular}

Fuel characteristics 100 y after discharge

Pu-238 fraction (kg Pu-238/kg Pu)

Pu-239 fraction (kg Pu-239/kg Pu)

Pu-240 fraction (kg Pu-240/kg Pu)

Pu-241 fraction (kg Pu-241/kg Pu)

$\mathrm{Pu}-242$ fraction $(\mathrm{kg} \mathrm{Pu}-242 / \mathrm{kg} \mathrm{Pu})$

Heat generation in one fuel assembly $(W)$

Gamma radiation (Sv/h at surface, midplane)

\begin{tabular}{|c|c|}
\hline & 0.0045 \\
\hline & 0.653 \\
\hline & 0.310 \\
\hline & 0.001 \\
\hline & 0.032 \\
\hline & 177 \\
\hline
\end{tabular}

\begin{tabular}{|c|c|c|}
\hline 0.0023 & 0.0005 & 0.0005 \\
\hline 0.701 & 0.705 & 0.705 \\
\hline 0.272 & 0.273 & 0.273 \\
\hline 0.001 & 0.032 & 0.001 \\
\hline 0.023 & 0.021 & 0.021 \\
\hline 397 & 417 & 417 \\
\hline 66.8 & 15.5 & 15.5 \\
\hline
\end{tabular}

Environment, Safety, and Health

\begin{tabular}{|l|c|c|c|c|}
\hline Dose during Pu mission reactor operations (person-Sv) & 33 & 22 & 31 & 43 \\
\hline Low level waste during Pu mission $\left(\mathrm{m}^{3}\right)$ & 3583 & 3600 & 3017 & 3200 \\
\hline Uniform LLW shipment rate during Pu mission ( $\left.\mathrm{m}^{3} / y\right)$ & 200 & 200 & 200 & 200 \\
\hline Spent fuel during Pu mission (no. of fuel assy) & 5384 & 1928 & 1713 & 1692 \\
\hline Spent fuel during Pu mission (MT) & 1630 & 1280 & 1233 & 1160 \\
\hline Spent fuel during Pu mission (m^3) & 551 & 303 & 344 & 340 \\
\hline
\end{tabular}




\subsubsection{Reactor Facility Operating Basis}

There are minimal technology needs for the ALWR option for disposition of weapon plutonium. MOX fuel has been used on a demonstration basis in both LWRs and PWRs in the United States. MOX fuel is currently used in other countries, and its use there is increasing. Primarily only confirmatory analyses and testing of special features (all related to fuel handling and performance) are needed to place the ALWRs in operation as opposed to a rigorous research and development program. The project schedules indicated in Table 1-1 take into consideration a concurrent program of confirmatory analyses and testing that does not influence the start of reactor power operation.

The discussion in this data report is based on the following general assumptions:

- The principal reactor facility features comprise reactors, reactor coolant systems, fuel receival and storage area, spent fuel storage pool, material handling systems, waste management systems, control system, power conversion system, security systems, and associated personnel facilities.

- Candidate sites have not been selected. It has not been determined whether the reactor facility will be privately owned or owned by the government. In either case, it is most likely that all operations will be conducted for the government by a private contractor.

- All facilities are to have a design life of 40 to 60 years. The spent fuel storage pool must be able to accommodate fuel assemblies for 10 years after reactor discharge.

- The reactor facility must meet all NRC licensing requirements.

- The reactor facility must comply with all applicable federal, state, and local laws and regulations; DOE Orders; and Executive Orders for protection of public health and safety, worker (i.e., occupational) health and safety, and the environment.

- Cost-effective, efficient generation of electricity is a design requirement.

- The reactor must operate on LEU fuel for the remainder of its useful life after completion of the plutonium disposition mission. MOX fuel delivered to the reactor facility (by the government) will be made from uranium enrichment process tails having an assay of $0.2 \%$ uranium-235. The reactor facility operator is to be responsible for the specifications and acceptance of all fuel.

- Waste generation is to be limited to the minimum practical level.

- Low-level waste (LLW) is to be treated and packaged into a solid form suitable for shipment to an appropriate LLW disposal facility. Interim storage facilities are to be provided to allow accumulation of LLW so that risks associated with interim storage and number and size of shipments are minimized.

- Mixed LLW is to be treated and disposed of in accordance with all applicable regulations. Interim storage facilities are to be provided to allow accumulation of mixed LLW so that risks associated with interim storage and number and size of shipments are minimized.

- Hazardous waste is to be shipped to a disposal facility that has a valid permit as required by the Resource Conservation and Recovery Act (RCRA). 
- Sanitary waste water is to be treated at the reactor facility to an on-site septic field or released to the local sewer system according to local regulations.

- Sanitary and industrial solid waste is to be disposed of in locally approved industrial landfills.

\subsubsection{Compliance}

\subsubsection{Rules, Regulations, Codes, and Guidelines}

The ALWR facility will be designed, constructed, and operated in compliance with all applicable Federal, State, and local statutes and regulations. Among all required permits and licenses, two figure most prominently: (1) obtaining U.S. Nuclear Regulatory Commission (NRC) approval of the plant design for the plutonium disposition mission, and (2) obtaining approval, in accordance with the National Environmental Policy Act (NEPA), of the environment report relating to the construction, operation, and decommissioning of the ALWR plutonium disposition facility. A summary listing of typical licenses and permits required for the facility is given in Table 1-2.

Each ALWR facility under consideration for the plutonium disposition mission is a variant of a respective advanced commercial reactor design. Some of these have undergone preliminary licensing review by the Nuclear Regulatory Commission for operation using a "conventional" reactor core utilizing uranium-oxide fuel. To greater or lesser extent, the original design of each ALWR facilities have already considered large loadings of MOX fuel. Adaptation of these designs to MOX fuel operation has also been studied in detail by the U.S. Department of Energy (DOE), and all are regarded as technically viable for the plutonium disposition mission. As a result, it is anticipated that no (or at most, minimal) design modifications would be necessary for plutonium disposition.

Several LWR systems and components are potentially affected by the conversion from $\mathrm{UO}_{2}$ operation to MOX operation and must therefore be addressed specifically in the licensing process. Additional control rods may be required to maintain required shutdown margin, equipment must accommodate higher soluble boron concentrations (for reactivity control), core and spent fuel cooling equipment must be sized to accommodate the higher decay heat loads associated with irradiated MOX fuel, design of the reactor vessel and internals must tolerate a greater flux of high energy neutrons than arises in uranium-fueled operation, radwaste systems may need to accommodate higher tritium activity in the primary coolant, and design of fuel storage and fuel handling facilities must safely accommodate MOX fuel. Additional facilities (or facility modifications) may be necessary to accommodate increased physical protection and safeguards requirements for MOX fuel.

Depending on the extent to which MOX operation has been considered in the original design, the primary licensing impact for the ALWR facilities under consideration should be limited to modifying system analyses and revising the applicable sections of the commercial reactor Safety Analysis Report (SAR). These revisions will have to be reviewed and approved by the NRC based on the fact that these revisions will include, among other things, certain changes to the 
Technical Specifications. ${ }^{1}$ However, the technical review by the NRC of these revisions should be straight forward in that departures from $\mathrm{UO}_{2}$ operation (already considered in the original design) should not involve any unreviewed safety questions.

Specific plant systems and topics that will require review for potential revisions for MOX fuel operation include (but are not necessarily limited to) the following:

- Residual Heat Removal System. Must handle higher long-term decay heat generation rates associated with MOX fuel. As a minimum, confirmatory analysis will be required to verify that higher decay heat load can be accommodated while still maintaining a high margin of safety.

- Spent Fuel Pool Cooling System. Must handle increased long-term decay heat of spent MOX fuel. As a minimum, confirmatory analysis will be required to verify that the increased long-term decay heat of spent MOX fuel can be accommodated while maintaining a high margin of safety.

- Component Cooling Water System. Must handle higher long-term decay heat generation rates associated with MOX fuel. As a minimum, confirmatory analysis will be required to verify that higher decay heat load can be accommodated while still maintaining a high margin of safety.

- Safety Injection System. Increased maximum soluble boron concentration required for MOX operation in the safety injection tanks must be analyzed to determine the new concentration required to maintain adequate shutdown margin and to assess the impact due to a malfunction of equipment important to safety compared to that analyzed for $\mathrm{UO}_{2}$ operation.

- Chemical and Volume Control System. Must handle higher soluble boron concentration in the reactor coolant system required for MOX operation. As a minimum, confirmatory analysis will be required.

- Radioactive Waste Management Systems. Liquid and gaseous radwaste systems must be reviewed to assure that they can handle, for example, higher coolant activity potentially resulting from MOX operation. This is particularly important if the ALWR facility is to be used also for tritium production.

- Reactor Internals. Must tolerate higher neutron fluence levels and higher heating rates associated with MOX operation. As a minimum, confirmatory analyses will be required to verify that higher neutron fluence levels and higher heating rates can be accommodated while maintaining an adequately high margin of safety.

- Core Design. A detailed thermal-hydraulic analysis and fuel performance analysis of the reference MOX core design will be required using NRC-approved design methodology. The thermal-hydraulic performance of the MOX core will require evaluation for all performancerelated and safety-related design bases. Additionally, a detailed neutronics evaluation of the MOX core design will be needed, including depletion isotopics, reactivity coefficients, control worths, and power distributions as a function of burnup. Detailed design is based on

\footnotetext{
${ }^{1}$ As a minimum, for example, operation with $\mathrm{MOX}$ fuel will require recalibration of set points for the reactor control system(s) and protection $\operatorname{system}(\mathrm{s})$.
} 
NRC-approved methods. Analyses will be performed for core stability and power distribution control.

- Accident Analyses. Loss-of-coolant accident (LOCA) and non-LOCA analyses, using NRCapproved licensing methodologies, will be necessary to demonstrate the reactor and safety systems meet licensing-basis safety criteria. Analyses to be performed will likely include the following: small-break and large-break LOCA; steam generator tube rupture; control rod misoperation and inadvertent withdrawal; control rod ejection events; steam line break.

- Severe Accident Evaluation. Evaluation of postulated severe accidents, including use of deterministic methodologies and a survey of relevant physical and experimental data, will be necessary to assess the significance of the MOX core on severe accident phenomenology and to assess the mitigation features of the plutonium disposition ALWR. The potential for recriticality following a severe accident and the consequences or mitigation of such recriticality will need to be addressed.

- Radiation Protection. Radioactive decay of plutonium isotopes in fresh MOX fuel requires provision of shielding in the fuel receipt, handling, and inspection area. Accordingly, minor design changes in shielding design may be necessary.

- Technical Specifications. The Technical Specifications developed for $\mathrm{UO}_{2}$ operation will need to be revised to reflect plant operation with a MOX core. These changes may include certain core physics parameters. 
Table 1-2. Typical Regulatory and Environmental Permits and Licenses for an ALWR Plutonium Disposition Facility

Permit or License

Construction Permit, Operating License

National Emission

Standards for Hazardous

Air Pollutants (NESHAP)
General Requirements

NRC approval of the selected ALWR plant. Approval of MOX fuel.

Radiological source term calculations. EPA approval prior to NESHAP application. Detailed procurement activities schedule required prior to start of construction. Applicability to specific facilities to be identified. Compliance with State requirements to be determined. $\begin{array}{ll}\text { Prevention of Significant } & \text { PSD permit process is independent of NESHAP. Controlled by } \\ \text { Deterioration (PSD) of Air } & \text { State of residence for facility. Approval required prior to start of }\end{array}$ Quality construction for facility that will emit regulated pollutants.

Air Quality

Diesel generators and concrete batch plant will be only source of air pollutants other than radionuclides. Limited diesel operating time per year may exclude need for permit.

governs impact on terrain due to timber harvest, altering groundwater flow patterns.

Governs effluent quality and quantity for all liquid discharges from facility. Storm water and process waste water control. An approved erosion control plan may be required.

Impact on protected wetlands.

Wetlands

(n)

Drilling of wells and water treatment systems. 
Table 1-2 (cont.) Typical Regulatory and Environmental Permits and Licenses for an ALWR Plutonium Disposition Facility

Permit or License

Sanitary Waste Water

Treatment

Transportation

Solid Waste Disposal

Federal Aviation Agency

Navigable Waters

Timber Harvest

National Historic

Preservation Act (NHPA)

\section{American Religious}

Freedom Act

Fish and Wildlife

Coordination Act
General Requirements

NPDES requires discharge characteristics, anticipated manpower loading (utilization) and schedule. Discharge paths must be identified. Permit required for the construction of the waste water treatment plant.

DOE Orders and Department of Transportation (DOT) requirements as appropriate. Safeguards for shipment of plutonium, mixed-oxide fuel.

Identify non-hazardous, non-radioactive waste disposal by type and rate.

Tall structures or cranes over 200 feet above ground level.

Modification to navigable water.

Forest management plan, if appropriate, to be developed.

Survey of artifacts or discovery of archaeological items in any area of disturbance during facility construction.

Disturbance of areas considered "sacred" to Indian cultures.

Endangered species and migratory bird impact. 


\subsubsection{Safeguards and Security}

The protection provided by the safeguards and security (S\&S) system needs to meet the requirements of the DOE Orders and NRC Regulations, and be complementary with International Atomic Energy Agency (IAEA) needs. Either, or both, agencies may have jurisdiction over parts of the plutonium disposition process. In general, DOE and NRC guidelines are very similar and early S\&S planning does not depend on which is the cognizant agency. DOE and NRC safeguards have the objective of protecting U.S. Special Nuclear Material (SNM), including weapon-grade plutonium, from theft, diversion, or sabotage by malevolent groups or individuals. IAEA safeguards have the slightly different, but largely complementary, objective of protecting SNM from diversion by the host nation itself. In general, as plutonium moves through the disposition process the types and quantities of the material will allow for a decrease in the level of protection.

The U.S. and international experience safeguarding SNM in processes similar to those required for the disposition of plutonium in reactors varies according to the step in the disposition process. The U.S. has the least experience in the three areas listed below. The U.S. experience with safeguarding commercial reactor fuel handling is directly applicable to the handling of spent mixed oxide fuel; new issues are introduced in the handling and final storage of spent particle fuel (e.g., as used in high-temperature gas reactors). It is in these areas where effort needs to be concentrated if the U.S. is to develop safeguards and security systems that are effective and efficient. Otherwise, much U.S. and international experience appears to be applicable.

The results of the Plutonium Disposition Study performed by the DOE Office of Nuclear Energy concluded that development of a safeguards and security program satisfying IAEA requirements is viable for each of the advanced (and, as well, each of the existing) reactor options considered. Although none of the vendors participating in the study provided a detailed compliance review of their respective designs against NRC and DOE S\&S requirements, a review that would be premature in this early stage of the design process, the DOE-NE technical review committee observed nothing that would preclude successful implementation of relevant DOE and NRC requirements.

\subsubsection{Environment, Safety, and Health}

The following discussion and Table 1-2 summarize general ES\&H requirements potentially applicable to ALWR disposition of plutonium disposition.

\subsection{Environment}

The National Environmental Policy Act requires that all federal agencies proposing major actions significantly affecting the quality of the human environment consult with other agencies having jurisdiction by law or special expertise on the subject and prepare a detailed statement of these environmental effects.

The NEPA process includes several steps. The first step is to determine whether NEPA applies to the proposed action. Some factors relevant to determining whether an action is a "major federal action" are the planning, time, resources or expenditure of the federal government. For the purpose of this discussion, it will be assumed that any plutonium disposition alternative would be significant enough to require the preparation of an Environmental Impact Statement (EIS). It is conceivable, however, that an EIS could be avoided if the selected alternative used 
only existing processes already covered by an EIS. The requirement for an EIS would also apply even if the project was undertaken by a private party, because it would be subject to regulatory approvals or permits. It is procedurally possible, however, that Congress could exempt the proposed action from NEPA due to over-riding national considerations.

\subsection{Safety}

In general, operational activities must be conducted in a manner that achieves safe and reliable operation. Administrative programs and controls should be-in place to ensure policies concerning quality are administered for each facility throughout the site. Provisions should be established for the control of purchased material, equipment, and services. Provisions should be established for the inspection of purchased material, equipment, and services. Provisions should be made to ensure that tools, gauges, instruments, and other measuring and testing devices are properly identified, controlled, calibrated, and adjusted at specified intervals. Provisions should be established to ensure the acceptability of special processes such as welding, heat treating, nondestructive testing, and chemical cleaning, and that special processes are performed by qualified personnel using qualified procedures and equipment.

\subsection{Health}

In general, a facility must ensure the health and well-being of its personnel. Adverse effects due to chemical, physical, and other environmental factors in the workplace must be evaluated and controlled as necessary. Systems need to be in place to measure effectiveness of control systems, including reporting of injuries, accidents, and other incidents. Facility personnel have a "right-toknow" of hazards in the workplace and there must be a system for communication of those hazards. Facility personnel must be adequately informed of chemical, physical, and biological stresses that may be encountered in their work environment. Appropriate surveillance of activities must be conducted to measure safety and health performance and ensure the continued effectiveness of controls. There must be a documented program for periodic monitoring of chemical, physical, and biological stresses to ensure maintenance of satisfactory health conditions. Monitoring results which evaluate the continuing adequacy of controls must be sent to line management and employees on a routine basis, in accordance with applicable Occupational Safety and Health Administration (OSHA) standards. The facility workplace must be free of uncontrolled physical hazards and be in compliance with DOE-prescribed occupational safety standards.

\subsubsection{Buffer Zones}

Facility buffer zones will be established in accordance with applicable NRC requirements.

\subsubsection{Decontamination and Decommissioning}

Decontamination and decommissioning of the ALWR plutonium disposition facility will be considered in accordance with applicable NRC requirements.

\subsubsection{Non-Safety/Safety Class}

Systems, structures, and components of the ALWR plutonium disposition facility will be identified in accordance with applicable NRC requirements. 


\subsubsection{Toxicological/Radiological Exposure}

\subsection{Management of Toxic and Hazardous Materials}

In general, hazardous materials (including the subset of hazardous wastes) are also subject to management requirements, restrictions, and reporting requirements. The extent to which hazardous materials are used in conjunction with a plutonium disposition alternative, will affect the regulatory cost of that alternative. An effective hazardous materials management program must be in place for the procurement, use, handling, storage, and shipping, and tracking of hazardous materials. Agencies at the federal, state, and local levels require reporting of hazardous materials storage, so that risks to the public can be evaluated. The reporting function may involve varying levels of sophistication. Hazardous materials inventories which fluctuate over time may require a sophisticated computerized tracking system. There may be considerable differences by location as to the perception of risk attributed to a project and the degree to which that risk should be controlled. Design, construction, and operation costs could be greatly affected by local requirements.

\subsection{Radiation Protection}

In general, emissions of radionuclides to the environment must be within applicable quantitative criteria, and, additionally, must be maintained at the lowest practicable level. A radiological environmental monitoring program must be in place to provide surveillance of the radiological effects of facility operations on the environment. A facility must demonstrate compliance with limits for radiation exposure to the public by documentation through appropriate technical measurements and calculations. Emissions of radionuclides are governed by the Atomic Energy Act (AEA) of 1954, and subsequent amendments, the Energy Reorganization Act of 1974, and the Department of Energy Organization Act. The Department of Energy is responsible for control of its activities and facilities using radioactive materials except for certain facilities that are licensed by the Nuclear Regulatory Commission. DOE regulates facilities under its jurisdiction, in part, by means of a collection of DOE Orders. DOE is also subject to EPA regulations related to the radiological protection of the environment, and may incorporate such regulations in the Orders by reference. Specific requirements will affect the cost of plutonium disposition alternatives to the extent they are applicable to the alternative.

\subsubsection{Waste Management}

In general, wastes must be properly characterized, managed, and disposed in order to avoid improper entry into the environment. Waste management covers all activities associated with the generation, transportation, treatment, storage, and disposal of solid, hazardous, and mixed wastes as well as such areas as underground storage tanks and waste minimization. Wastes must be safely and effectively treated or recycled with a minimum potential for release of contaminants to the environment. Wastes must be safely accumulated, transferred, stored, and disposed with a minimum potential for release of contaminants to the environment. Wastes must be safely transported using proper packaging, placarding, marking, and labeling, means of transport, and documentation. A program must be in place to ensure that the physical, chemical, and radiological characteristics of all wastes managed at the facility are adequately determined and that waste characterization related activities are performed in accordance with all applicable DOE, Federal, state, and local requirements. Underground storage tanks must be managed to minimize the potential for releases to the environment. Records must be maintained to demonstrate that wastes are managed in an environmentally sound manner. 
The primary regulations that address the waste management program are the Resource Conservation and Recovery Act (RCRA), DOE Order 5400.3 for hazardous and radioactive mixed wastes, DOE Order 5820.2A for radioactive and mixed wastes, and state statutes and regulations.

\section{References}

1. Study of Plutonium Disposition Using The GE Advanced Boiling Water Reactor (ABWR), GE Nuclear Energy Report NEDO-32351, San Jose, CA, April 30, 1994

2. Screening Study for Evaluation of the Potential for System 80+ to Consume Excess Plutonium, ABB-Combustion Engineering Report, Windsor, CT, April 30, 1994

3. PDR Plutonium Disposition Study Phase II Final Report, Westinghouse Electric Corporation Report, Monroeville, PA, April 30, 1994.

4. World Nuclear Outlook 1994, Department of Energy Report, DOE/EIA-0436(94), December 1994.

5. Borg, I. Y. and C. K. Briggs, U. S. Energy Flow - 1993, Lawrence Livermore National Laboratory Report, UCID-19227-93, October 1994.

6. Annual Energy Outlook 1994, - With Projections to 2010, Department of Energy Report, DOE/EIA-0383(94), January 1994. 


\subsection{ADVANCED (EVOLUTIONARY) LIGHT WATER REACTOR DESCRIPTION}

\subsection{General Facility Description}

The descriptions in this section are generally taken from information prepared by General Electric, ABB-Combustion Engineering, and Westinghouse Electric in support of the DOE-NE Plutonium Disposition Study (Refs. 1-3).

\subsubsection{Functional Description}

Light Water Reactors (LWRs) use common ("light") water as both the moderator and the coolant. LWRs are either boiling water reactors (BWRs) or pressurized water reactors (PWRs). Fission energy, manifested as heat in the fuel rods, is transferred to the water coolant. The water coolant is subsequently allowed to form steam to drive a turbine-generator to produce electricity. After leaving the turbine, the steam is condensed and returned to the power conversion process. As in all heat engines, conversion of heat to another form of energy, such as electric energy, requires that a portion of the heat be rejected. As noted in Table 1-1, the nominal thermal efficiency of the four ALWR types being considered is about $1 / 3$. Thus $2 / 3$ of the fission energy will be dissipated to the atmosphere (e.g., via cooling towers) or to a neighboring body of water ("once-through" cooling).

In a BWR, the pressure of the water in the reactor is maintained at the saturation pressure (approximately $7 \mathrm{MPa}$ ) consistent with the desired steam temperature at the turbine inlet. Boiling takes place in the reactor core and wet steam (approximately $15 \%$ quality) flows upward through passive steam separators and dryers at the top of the reactor pressure vessel. The separated dry steam is delivered to the turbine. The liquid water is recirculated through the reactor along with the condensed steam returned from the turbine condenser. The ABWR, one reactor type being considered for the new reactor plutonium disposition option, is depicted in Figs. 2-1 and 2-2.

In a PWR, the pressure of the water is maintained at a sufficiently high pressure (about $15 \mathrm{MPa}$ ) that boiling does not significantly occur in the reactor core. The hot saturated liquid is circulated to one or more heat exchangers, called steam generators, because water is boiled to a high quality and dried in a secondary circuit. Dry steam formed in the secondary circuit flows to the turbine inlet, through the condenser, and is returned to the steam generator. The primary water leaving the steam generator is returned to the reactor. Water in both the primary and the secondary circuits flows in a closed loop. The ABB-Combustion Engineering (ABB-CE) System 80+ PWR facility is shown in Fig. 2-3 and the arrangement of the reactor and the steam generators for the Westinghouse Plutonium Disposition Reactor (PDR) 600 PWR is depicted in Fig. 2-4.

The flow of surplus (e.g., excess weapon) plutonium in the form of MOX fuel assemblies, independent of the reactor type chosen, is qualitatively depicted in Figs. 2-5a and 2.5b for the large and small ALWR facilities, respectively. These figures show all input and output streams of consequence. Quantitative data for the input and output flows are given in Section 1, Table 1-1 for each ALWR type.

Fuel assemblies will be delivered to the reactor site on a pre-arranged schedule, by rail or (more likely) by truck transport. After their residence time in the reactor, these fuel assemblies will be 
allowed to cool in the spent fuel storage pool on site for 10 years. At that time they will be shipped, again by truck (more likely) or rail transport, to the government spent fuel repository (not currently in existence). ${ }^{\prime}$ Incoming fresh fuel will contain less than $7 \%$ plutonium based on the heavy metal content in the fuel assembly. The spent fuel will generally contain about $5 \%$ plutonium.

Specific fuel loading strategies for the ALWRs differ from each other. For the ABWR type, slightly less than $1 / 3$ of the assemblies are removed at each "reload". This means that most of the assemblies will reside in the core for three cycles and that a few assemblies will reside in the core for a fourth cycle. The assemblies that are unloaded are selected so that all fuel will have nearly the same burnup. For the two PDR types, since the number of assemblies in the core is not exactly divisible by three, there will be a small variation in the number of assemblies reloaded. These small variations have been neglected in the quantitative data presented here. For the System $80+$ type, the fuel strategy is such that the fuel is merely relocated ("shuffled") in the core about once a year to homogenize the burnup experienced. Every fourth year all the fuel assemblies are replaced. At the end of the plutonium disposition mission, some fuel assemblies in the final reloads may not contain MOX fuel. At that time, low-enriched uranium (LEU) fuel will be phased in and for the remainder of the reactor life, all reloads will consist of only LEU fuel.

All waste generated at the ALWR site will be treated onsite for offsite disposal in accordance with applicable regulations. Three principal waste management systems will deal with: liquid low-level waste (LLW), solid LLW, and offgas treatment. Treated liquid waste will be returned to the reactor whenever practical or converted to solid LLW. These waste management systems will generally be no different than those used in existing LWRs in the United States.

The ALWR facility also provides facilities for a number of functions such as administration, training/simulation, dining service, emergency operation, environmental monitoring, fire protection, contaminated laundry services, maintenance, medical services, warehousing, operations control, physical protection system, security, and utility services.

\subsubsection{Plot Plan}

This information is provided in Section 3.1, "Site Map", for the reactor types considered.

\footnotetext{
${ }^{1}$ The lack of a geologic repository may require that an onsite dry storage area, where spent fuel assemblies could be stored until such time as a repository becomes available, be created in order to complete the plutonium disposition mission. The FMDP Reactor Alternative Team has identified a commercially available dry spent fuel management system that is currently licensed and in service at several U.S. reactor sites (Ref. 4). The system employs ventilated reinforced concrete Horizontal Storage Modules (HSMs) to store spent fuel assemblies that are sealed in stainless steel Dry Shielded Canisters (DSCs). Each HSM has internal flow passages to promote natural convection cooling for the enclosed DSC. A dry storage complex of $40 \mathrm{HSMs}$ was determined adequate for ten years of spent fuel storage for a large (i.e., $3500 \mathrm{MWt}$ class) existing or evolutionary LWR.
} 


\subsubsection{Building Descriptions}

Figure 2-6 shows a conceptual cutaway building elevation for the BWR ALWR nuclear island. Figures 2-7 through 2-9 show equivalent information for the large PWR facility; information for the small PWR facility is conceptually identical.

Table 2-1 provides general building descriptions and approximate footprint requirements for a large ALWR, based on ABWR data.

Table 2-1. General Building Descriptions - Large ALWR

\begin{tabular}{|c|c|c|c|c|}
\hline Building Name & No: & $\begin{array}{c}\text { Footprint } \\
\left(\mathrm{m}^{2}\right)\end{array}$ & Levels & Construction Type \\
\hline Reactor Building & 2 & 3900 & 5 & Reinforced concrete \\
\hline Turbine Building & 2 & 8640 & 4 & Reinforced concrete \\
\hline Control Building & 2 & 1400 & 4 & Reinforced concrete \\
\hline Radwaste Building & 1 & 6600 & 1 & Reinforced concrete \\
\hline Service Building (Hot) & 1 & 3510 & 1 & Reinforced concrete \\
\hline Spent Fuel Storage & 1 & 3160 & 1 & Reinforced concrete \\
\hline Fresh Fuel Storage* & 1 & 3200 & 1 & Reinforced concrete \\
\hline Access Building & 2 & 1000 & 1 & Reinforced concrete \\
\hline Pump House & 2 & 1250 & 1 & Reinforced concrete \\
\hline Warehouse & 1 & 4300 & 1 & Steel frame or concrete \\
\hline Switch Yard & 2 & 7100 & 1 & Outside equipment \\
\hline Cooling Towers & 8 & 800 & - & \\
\hline Heat Sink Pool & 2 & 10000 & 1 & Reinforced concrete \\
\hline
\end{tabular}

*only building with a function unique to the plutonium-disposition ALWR, i.e., to safeguard fresh MOX fuel 


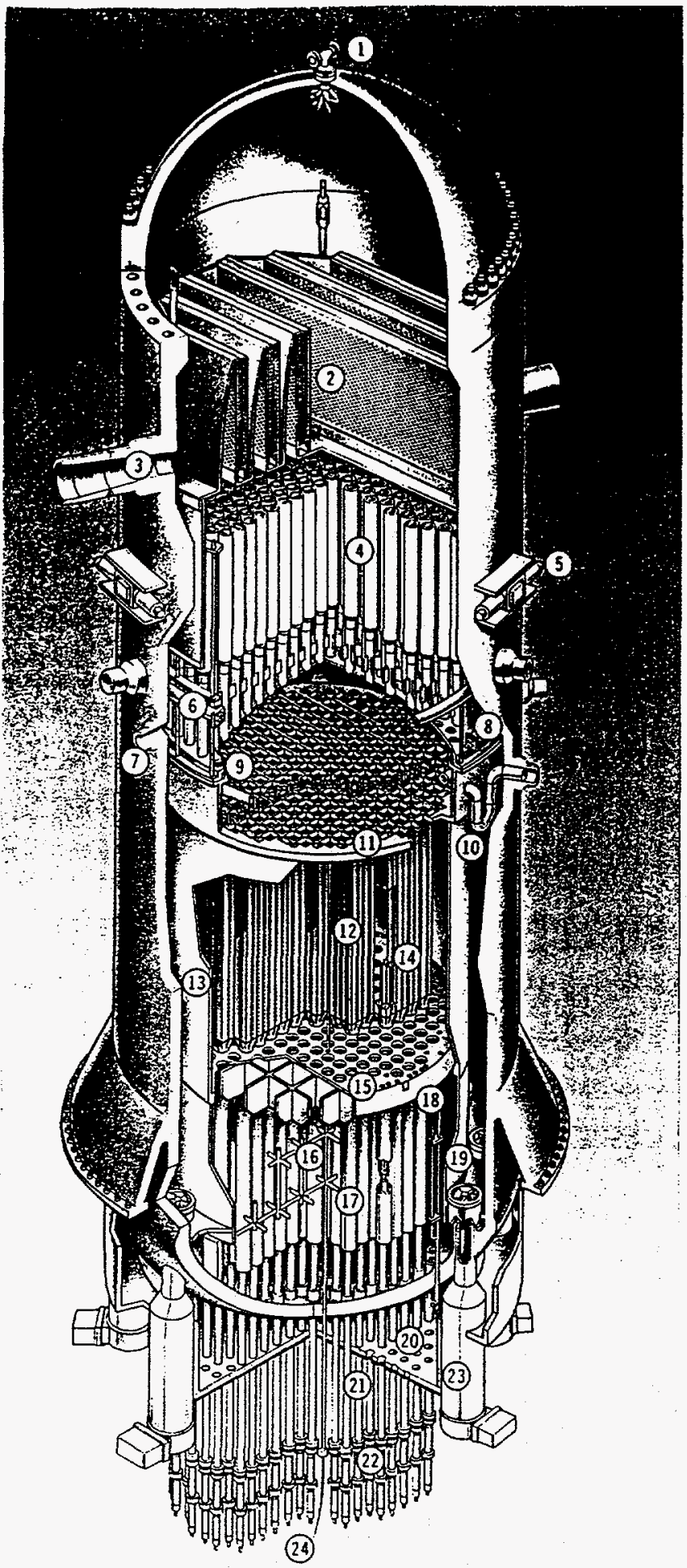

\section{Advanced Boiling Water Reactor Assembly}

1 Vent and Head Spray

2 Steam Dryer

3 Steam Outlet Flow Restrictor

4 Steam Separators

5 RPV Stabilizer

6 Feedwater Sparger

7 Shutdown Cooling Outlet

8 Low Pressure Flooder (LPFL) and Shutdown Cooling Sparger

9 High Pressure Core Flooder (HPCF) Sparger

10 HPCF Coupling

11 Top Guide

12 Fuel Assemblies

13 Core Shroud

14 Control Rod

15 Core Plate

16 In-Core Instrument Guide Tubes

17 Control Rod Guide Tubes

18 Core Differential Pressure Line

19 Reactor Internal Pumps (RIP)

20 Thermal Insulation

21 Control Rod Drive Housings

22 Fine Motion Control Rod Drives

23 RIP Motor Casing

24 Local Power Range Monitor

Fig. 2-1 Advanced Boiling Water Reactor Assembly 

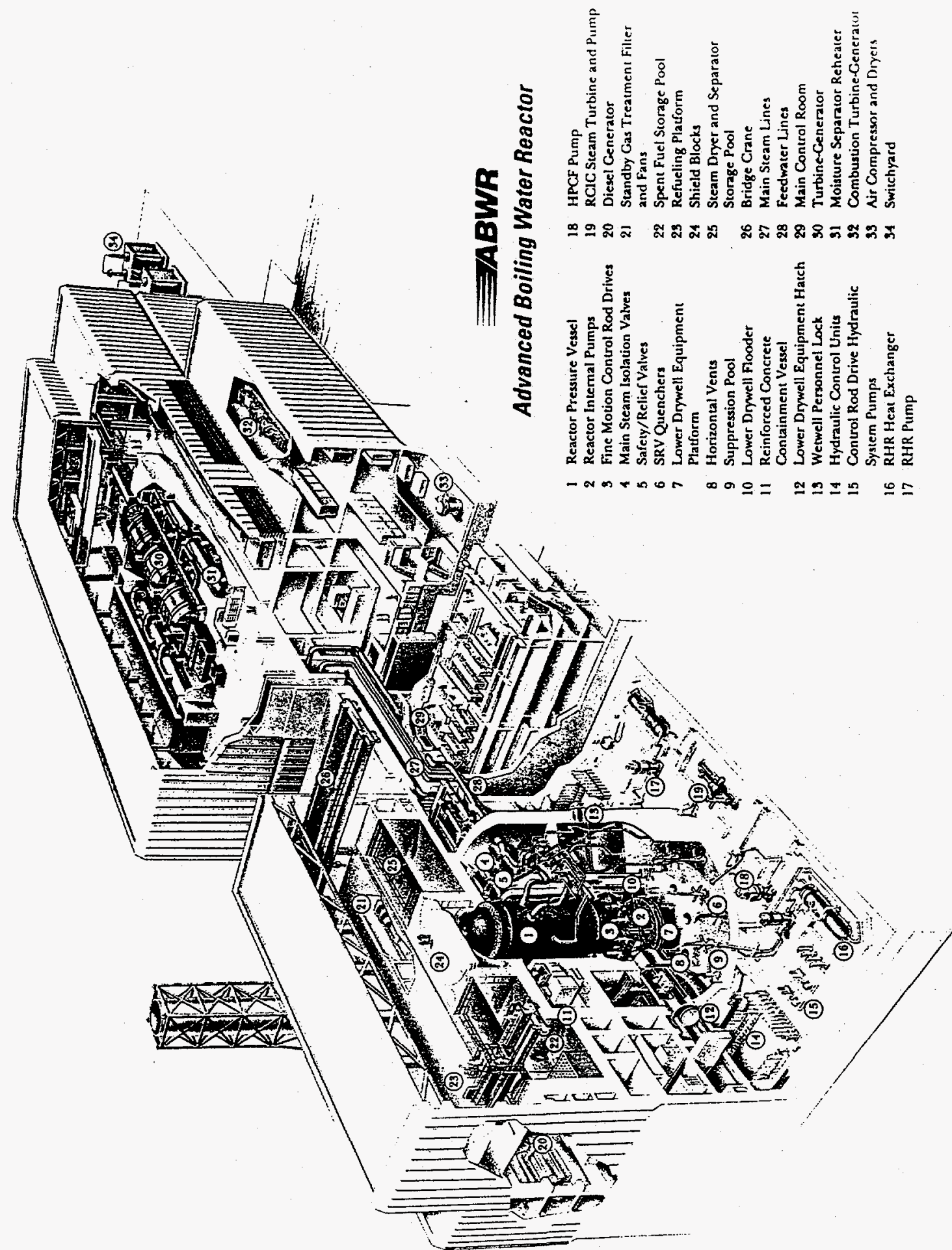

ALWR PEIS Data, Rev. 0

$2-5$

February 9, 1996 


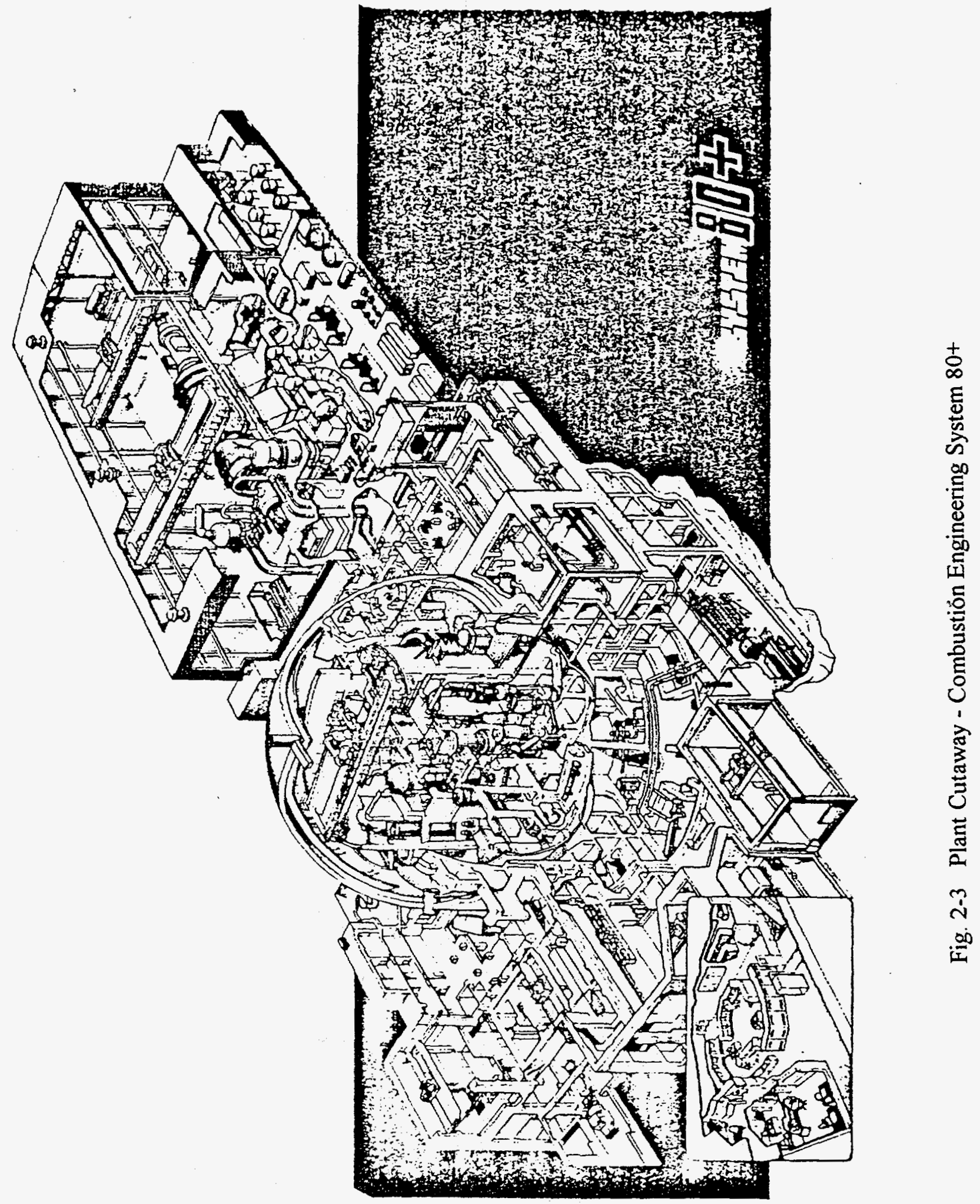

ALWR PEIS Data, Rev. 0

$2-6$

February 9,1996 


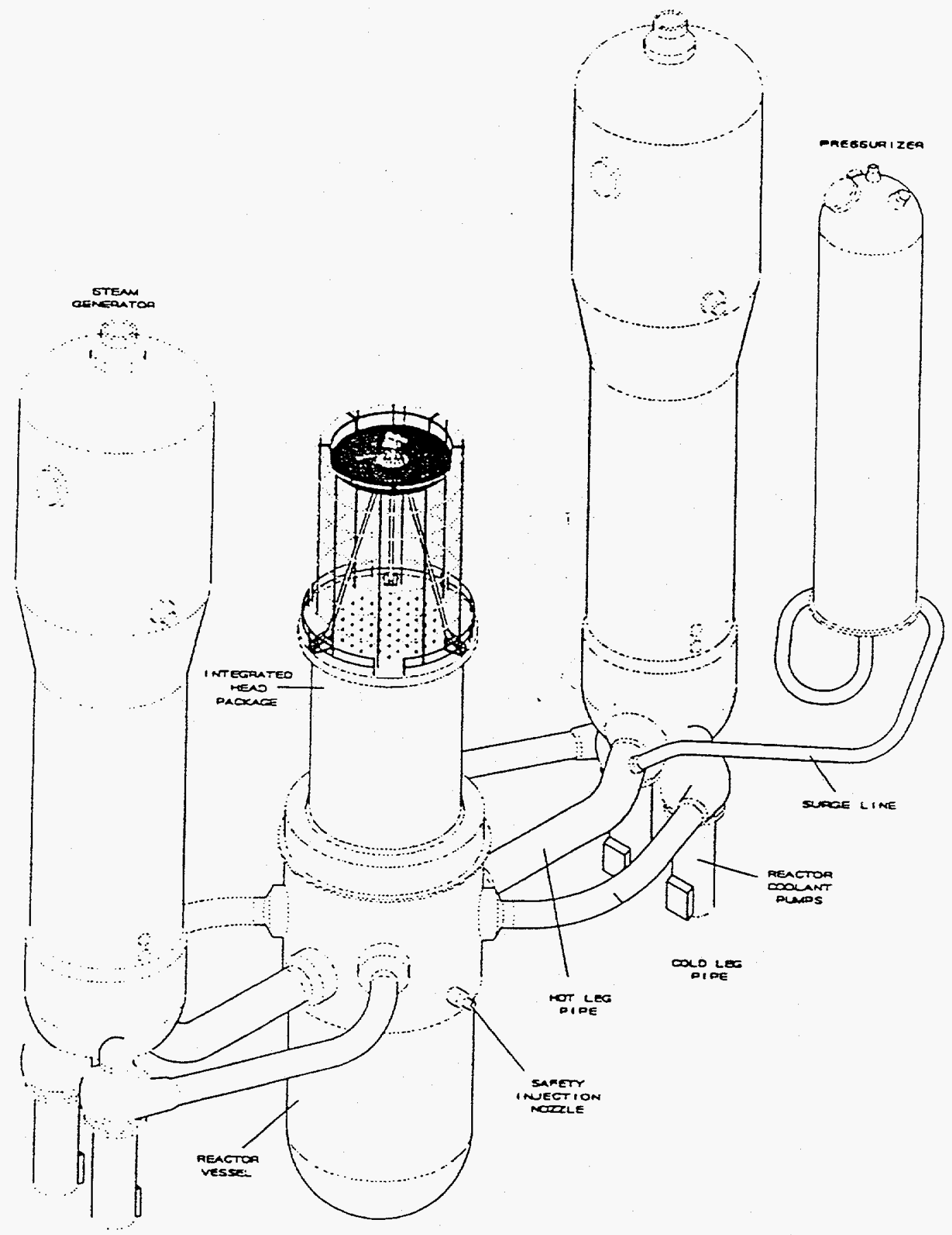

Fig. 2-4 Small ALWR Reactor Coolant Loop Isometric (PDR600) 


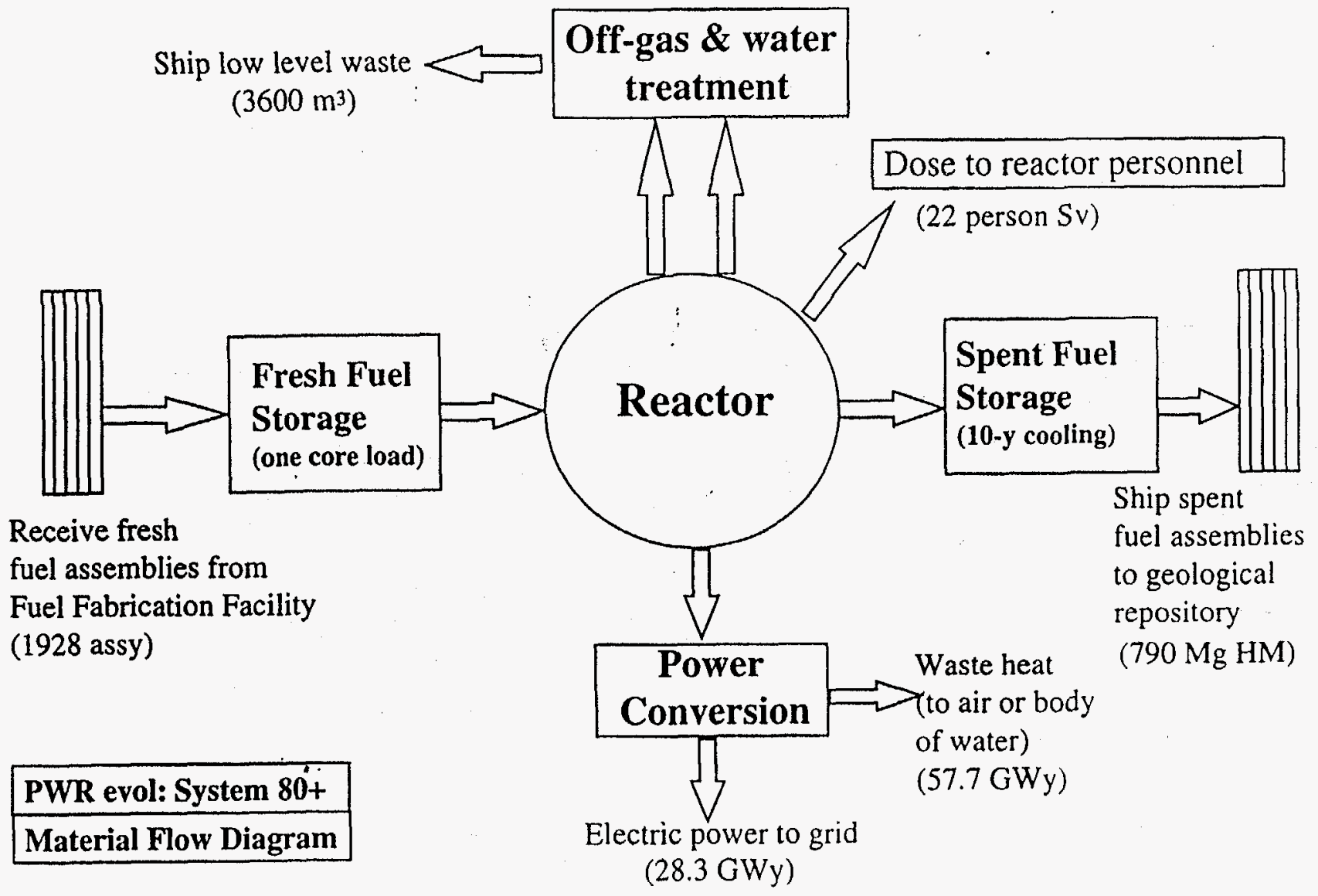

Fig. 2-5a Facility Flow Diagram - Large ALWR (ABB-CE System 80+) 


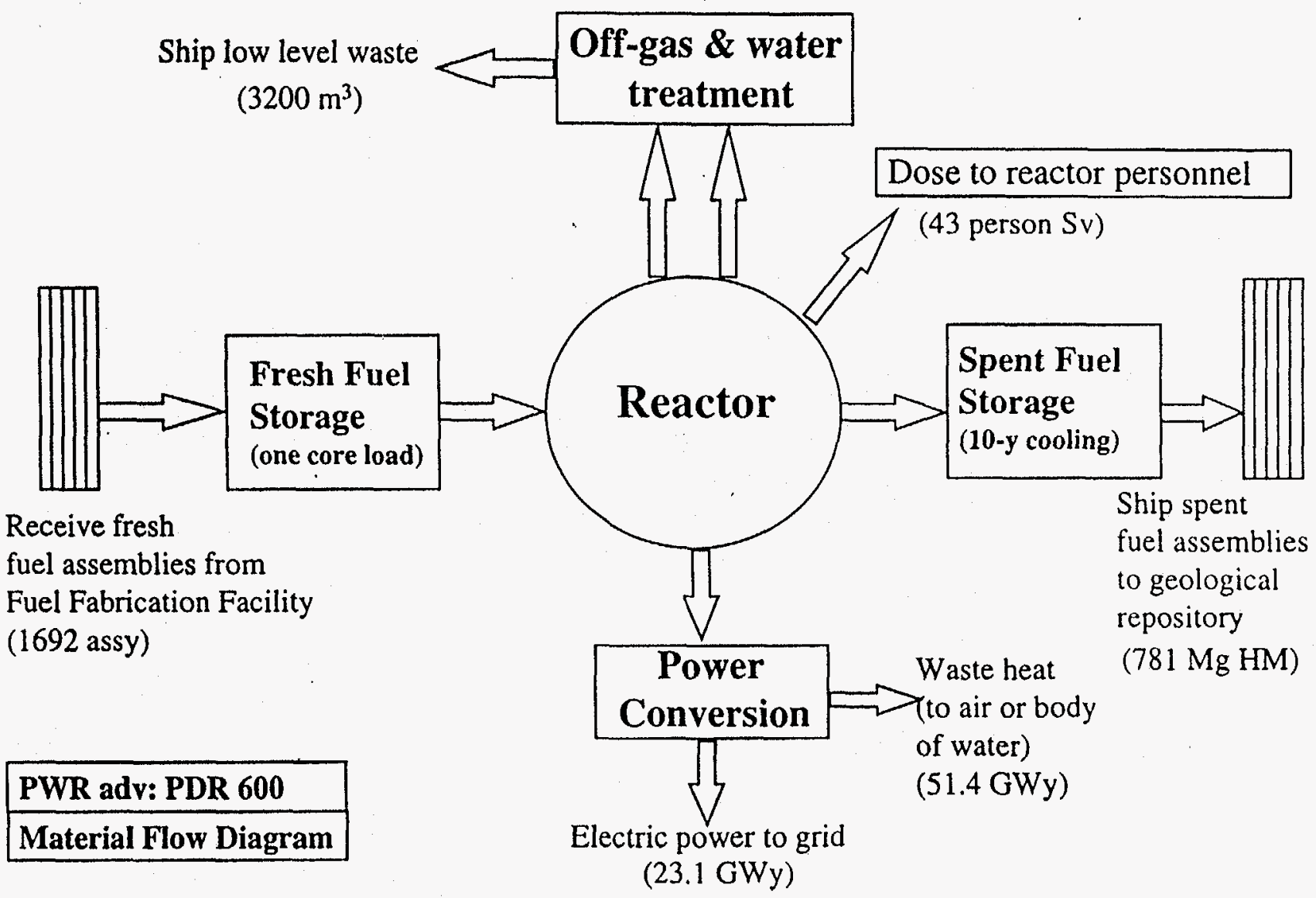

Fig. 2-5b Facility Flow Diagram - Small ALWR (Westinghouse PDR-600) 


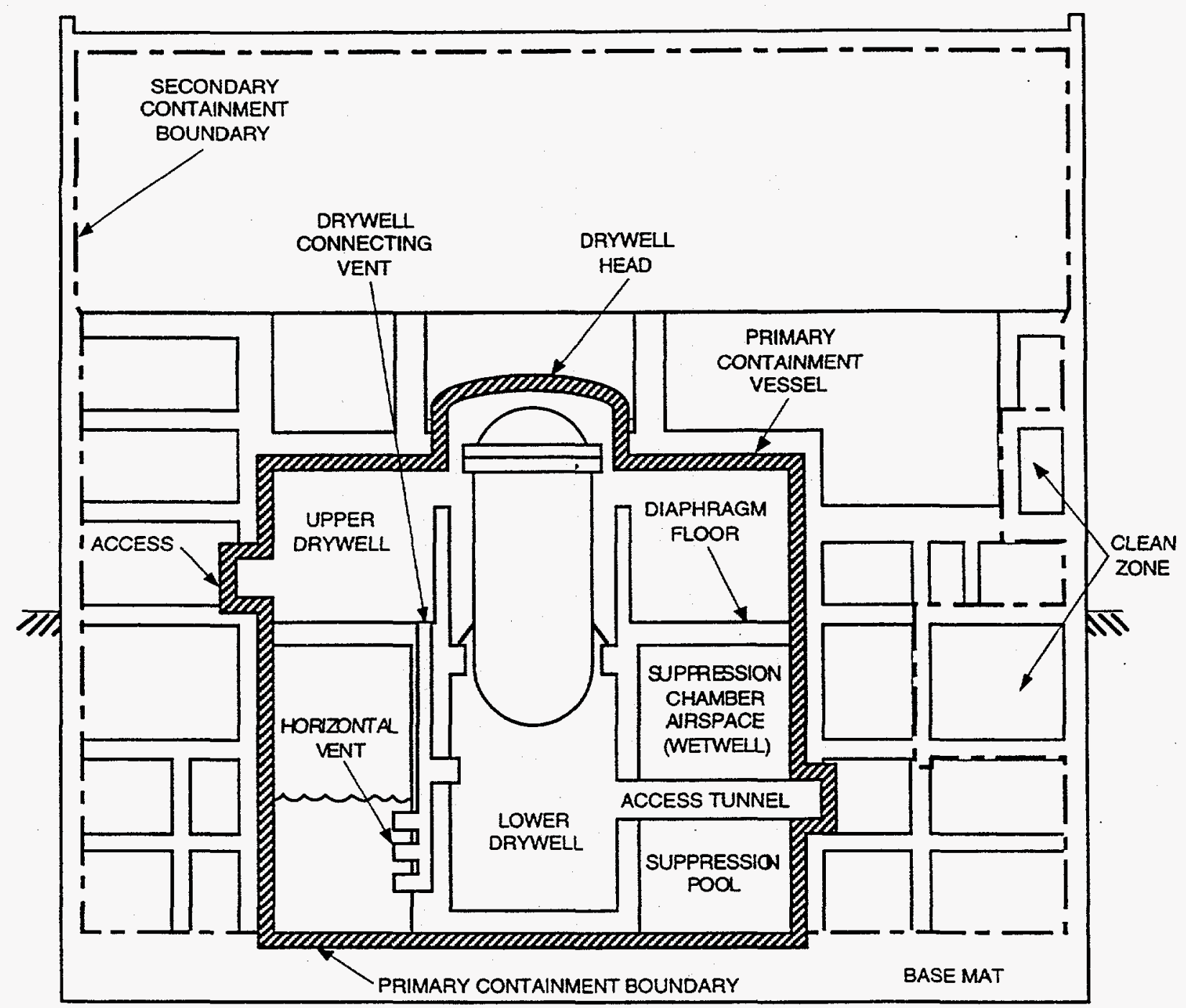

Figure 2-6 Conceptual View of ABWR Nuclear Island 


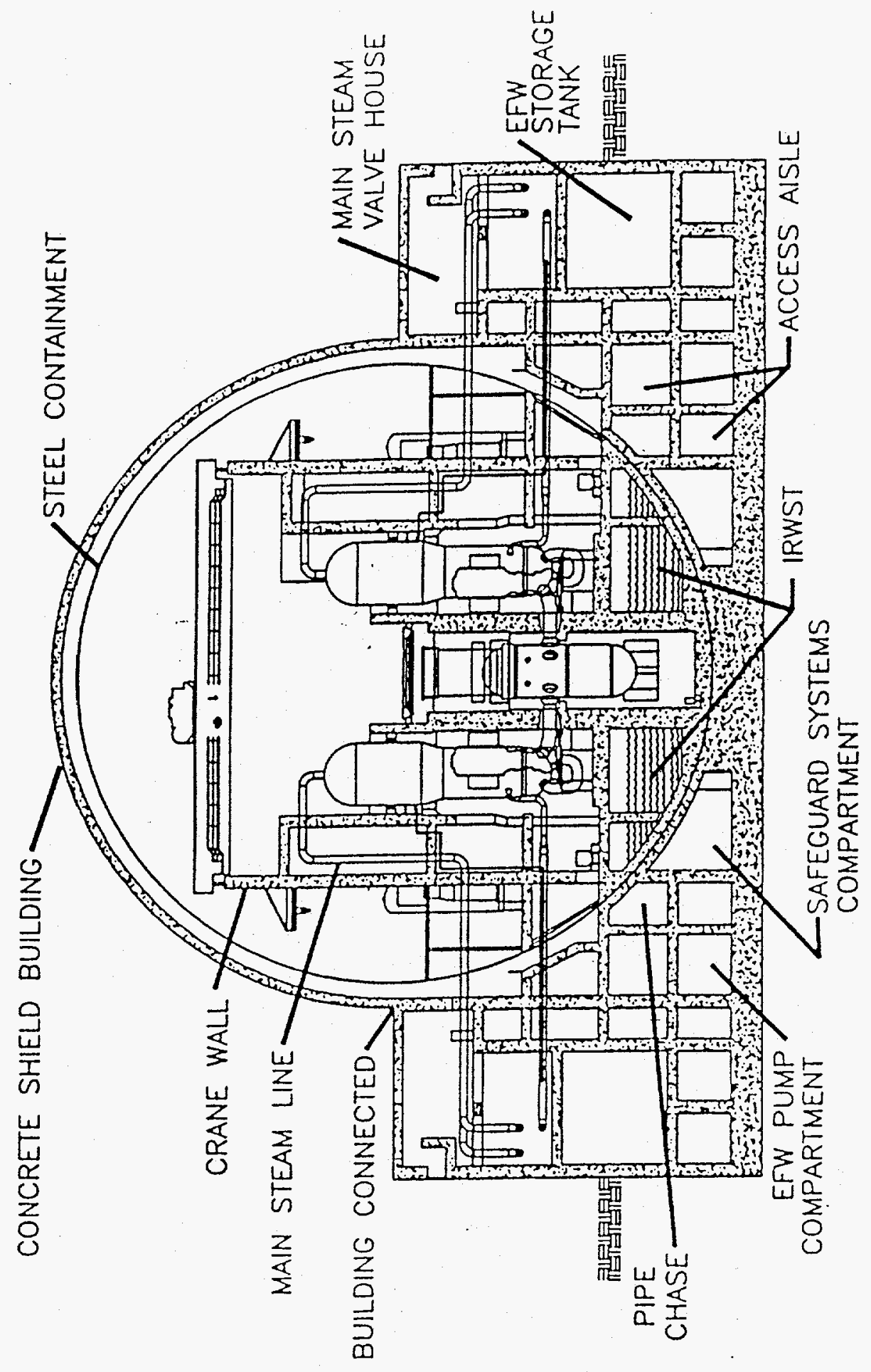

告 


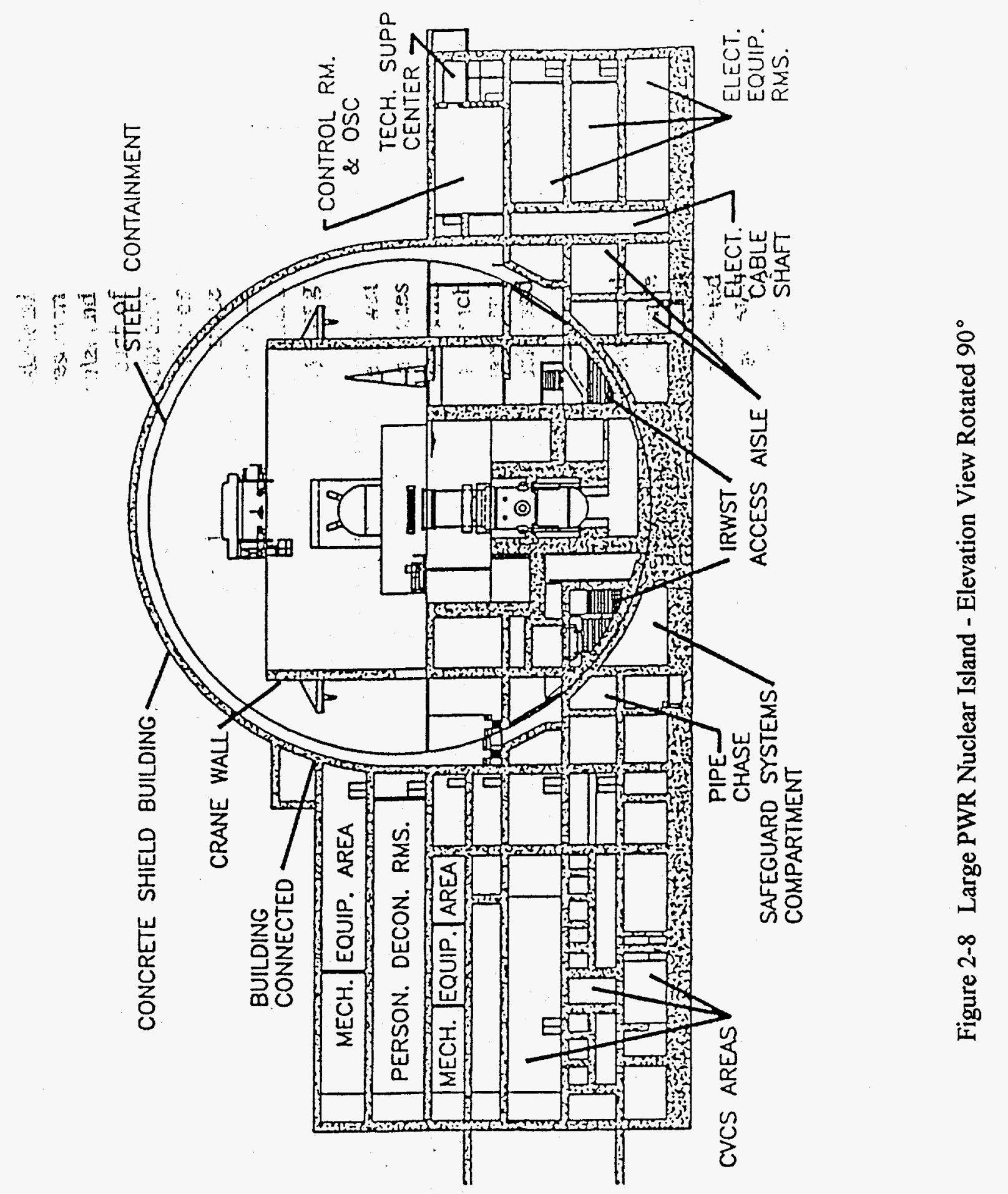




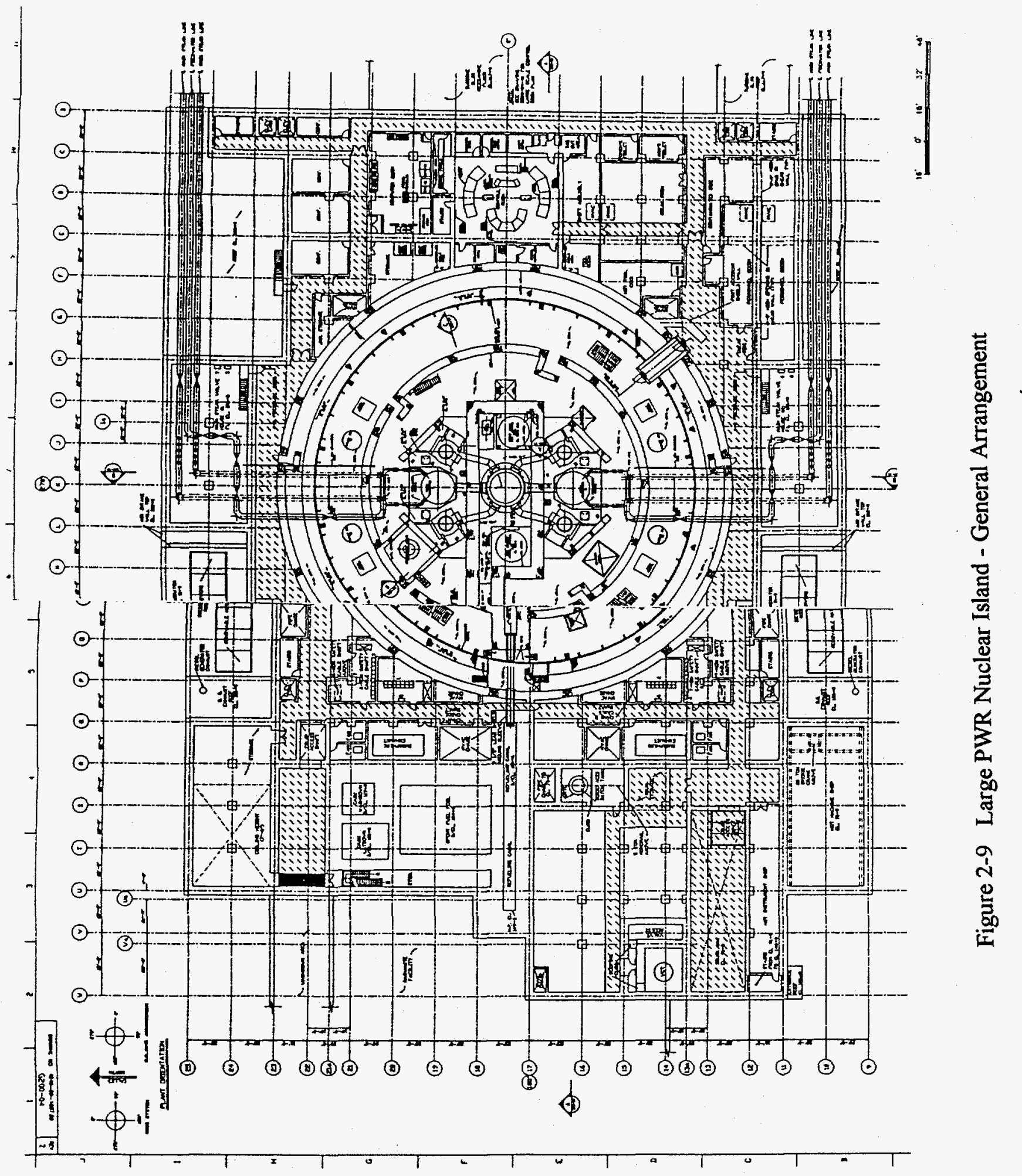

ALWR PEIS Data, Rev. 0 


\subsection{Design Safety}

Although the plutonium disposition ALWR is a DOE facility, the presumption is made (see Section 1.2.3) that the facility will obtain a U.S. Nuclear Regulatory Commission (NRC) license for all aspects of plant design equivalent to commercial nuclear power plants. Those aspects of the facility where DOE has specific regulatory authority (e.g., transportation, safeguards and security, material receiving areas) shall comply with appropriate DOE criteria. The applicable DOE and NRC design criteria presented in this section are general because the facility site has not been selected. Revision to the criteria will be made to include site-specific detail when the site is known.

It is DOE policy to recognize public and worker health and safety, environmental protection, operation, and cost in the design process for a DOE facility. DOE Order 6430.1 A provides mandatory, minimally acceptable requirements for facility design. The design issues that are not covered in this Order shall be governed by the regional codes and national standards commonly used in the engineering community.

The SSCs of the facility shall be designed to protect the workers, the general public, and the environment from the impacts of natural phenomena hazards. DOE Order 5480.28 provides requirements for facility design for natural phenomena hazard (NPH) mitigation. DOE Order 5480.30 provides design requirements specifically for nuclear facilities such as reactors and their safety systems. It specifies that the design criteria for reactor shall be in accordance with the provisions given in DOE Order 5480.28.

The DOE facilities are categorized into three hazard categories based on the safety classifications. DOE Orders 5480.23 specifies the safety classifications to be established by safety analysis evaluating the adequacy of the safety bases of the facility. DOE-STD 1027-92 provides hazard categorization and guidance for compliance with DOE Order 5480.23. The hazard categorization of a facility is also established on the basis of material inventory. Hazard Category "1" (HC-1) denotes a "high hazard" facility such as a nuclear reactor. HC-2 and HC-3 facilities are nuclear facilities with inventory over and below the Category-2 threshold, respectively. Based on the hazardous material inventory, the facilities are also classified to be high, moderate, and low hazard (HH, MH, LH) facilities.

DOE Order 5480.28 establishes five Performance Categories (PCs) which correspond to three hazard categories. DOE-STD $1020-94$ provides the target probabilistic performance goals (PGs) for each PC and guidelines for SSC preliminary performance category identification. PCs and corresponding PGs should be selected by engineers with knowledge of systems, safety requirements, and facility operations such that DOE policies are met.

The ALWR is a nuclear facility which processes fissionable materials; therefore, it is a Hazard Category $1(\mathrm{HC}-1)$ and High Hazard $(\mathrm{HH})$ facility. Buildings in the facility except the reactor building and the fissionable material-related storage building could belong to $\mathrm{HC}-2$ and $\mathrm{HC}-3$ depending on their operations and material inventories.

DOE-STD 1021-93 specifies the annual PGs of $1 \times 10^{-5}$ and $1 \times 10^{-4}$ for the PC-4 and PC-3 facilities, respectively. The commercial ALWR meets the safety goals of $1 \times 10^{-5} /$ year for core 
damage and $1 \times 10^{-6} /$ year for larger release. The DOE provisions for PG-4 equals to the NRC standard for core damage and leads to an annual probability of large release at $1 \times 10^{-6}$.

The design criteria for the facilities of PC-4 through PC-1 are provided in the DOE-STD 1020-94. The PC-0 facilities does not require specific NPH design and may comply with the Uniform Building Code (UBC) and other national standards. The safety-related SSCs are classified to be Safety-Class or Safety-Significant. They shall be designed to withstand the loading imposed by the normal and abnormal operations and by the natural phenomena events without loss of capability to perform their safety functions.

The Standard puts the emphasis in the importance of a five-step design approach to ensure the integrity of the facility. The steps include determining the NPH loads at specific probability, choosing the appropriate design procedures, evaluating the structural responses against the structural capacities, designing the proper detailing to ensure the structural performance, and applying quality assurance review. To achieve the performance goals from the probabilistic hazard level depends on the intentional conservatism in the five steps of design process and a response scale factor provided in the Standard and.

The NRC design bases for protection against natural phenomena are provided in the Code of Federal Regulations, 10 CFR, Part 50, Appendix A. The SSCs important to safety shall be designed to withstand the effects of natural phenomena without loss of capability to perform their safety functions. The design shall reflect appropriate consideration of the most severe natural phenomena that had been historically recorded for the site with sufficient margin. The responses of the SSCs from the natural phenomena shall be combined with those induced by the normal and accident conditions.

\subsubsection{Earthquake}

This chapter provides the seismic design criteria specifically to ensure that the facility is designed to mitigate seismic damage. Judgment has been made to balance the safety of the workers and public and the cost of fabrication and construction of the facility. NRC seismic acceptance criteria for nuclear power plants have been continuously revised. Some given provisions are referred to the revised 10 CFR 100, Appendix B and related regulatory draft guide.

\subsubsection{Seismic loading specification}

DOE-STD 1020-94 specifies a seismic $P_{H}$ for each $P G$. If the $P_{H} s$ for the chosen site are not available in the Standard a probabilistic seismic hazard assessment shall be performed to develop a mean seismic hazard curve based on the soil characteristics and the seismicity of a facility with the consideration of uncertainties as discussed in DOE-STDs 1022, 1023, and 1024.

The design basis ground motion is the acceleration associated to the specified $P_{H}$ for the $P G$. The earthquake which is capable of generating the design basis ground motion is called the design basis earthquake (DBE). For PC-2 and PC-1 facilities, a site-specific seismic hazard curve is not required. When a site-specific seismic hazard curve is not available provisions in a current issue of the UBC for ground motion is adequate. 
NRC classifies the SSCs in quality classification systems related to specified national standards (ANSI/ANS-52.1-1983). Regulatory Guide 1.26 provides the SSC classification criteria. For seismic design Regulatory Guide 1.29 provides the method for identifying and classifying those features of light-water-cooled nuclear power plants that should be designed to withstand the effects of earthquakes to be Seismic Category I SSCs. The remaining SSCs are Non-Seismic Category I SSCs.

The NRC seismic provisions in the 10 CFR 100, Appendix A, specifies Safe Shutdown Earthquake (SSE) for the design of the SSCs that are important for safety. The SSE shall be defined by response spectra corresponding to the expected maximum ground accelerations in accordance with the provisions in Regulatory Guide 1.60. Currently NRC is in the process of updating site seismic characterization method in the Appendix B of the 10 CFR 100. The Draft Guide 1032 describes the implementation of a probabilistic method for this Appendix B. The seismic loading specification shall comply with the Appendix B and the DG 1032 when they are finalized.

\subsubsection{Design procedures for seismic responses evaluation}

To meet the DOE criteria, the elastic seismic responses of a PC-4 or PC-3 facility shall be estimated by dynamic analyses using response spectrum or time history method. The calculated elastic seismic responses shall be multiplied by a scale factor provided in DOE-STD 1020-94 to ensure that the PG is achieved. For embedded buildings, soil-structure interaction analyses shall be performed to properly capture the soil effect to the SSCs.

The dynamic analyses must consider three orthogonal components of earthquake ground motion (two horizontal components and one vertical component). One response spectrum shall be generated to represent two horizontal ground motions and one spectrum for vertical ground motion. Two time history data sets shall be generated from two design response spectra.

When the response spectrum method is used, the modal responses combination for each direction is by double sum approach as recommended in ASCE Standard 4-86. The combination for the three directional components is the square root of the sum of the squares (SRSS) with the ratios of $1: 1: 1$.

The damping value used in responses calculations shall be selected based on three response levels (RLs) as given in DOE-STD 1020-94. To account for the inelastic energy absorption capacity of the structure the Standard allows to reduce the elastic response by a reduction factor $\mathrm{F}_{\mathrm{u}}$. The reduction factor shall be applied to the responses evaluation only when the responses level is above yield.

The seismic responses shall be combined with the non-seismic responses to obtain the total response demand in accordance with the provisions in ACI-349-85. Note that the seismic and wind responses are mutually exclusive. The structural capacity shall be larger than or equal to its demand for acceptance.

The seismic responses of a PC-2 or PC-1 facility shall be estimated by dynamic or static analyses. It is adequate to use the distributed seismic load over the height of the structure in static base shear approach as provided in UBC. The parameter $\mathrm{Z}$ (peak ground acceleration) shall 
be obtained from DOE-STD 1020-94 or from the UBC Seismic Zonation Map. To account for the inelastic energy absorption capacity of the structure the UBC allows reduction of the elastic responses by a reduction factor $\mathrm{R}_{\mathrm{w}}$.

To meet the NRC criteria, the Seismic Category I SSCs shall be designed to withstand the SSE. The seismic responses of the Seismic Category I SSCs shall be calculated by performing dynamic analysis (response spectrum or time-history). Regulatory Guide 1.61 delineates the damping values to be used in the elastic modal dynamic seismic analysis. The facility that rests on soft ground or is embedded shall be analyzed for soil-structure interaction effects.

Regulatory Guide 1.92 provides methods for combining modal responses and spatial components in seismic response analysis. The combination of three directional components shall be by SRSS with the ratios of $1: 1: 2 / 3$ where $2 / 3$ is the vertical component. The seismic responses shall be combined with those responses to normal and accident conditions. The load combination method is provided in the NRC Standard Review Plan, Section 3.8.4.

Ground motion obtained from the seismic hazard curve are not for the design of the systems and components which are located on the floors or walls of a building, such as equipment, building cranes, and piping. The floors of the building experience response magnification depending on their heights above ground. The structural responses (in-structure or floor response spectrum or time history data) at the systems or components attachment points in the structures shall be used for the design of the systems, components, and equipment anchorage.

\subsubsection{Design detailing}

The SSC anchorage, especially for the piping and equipment of the survival of emergence systems, shall be able to withstand the seismic loads without loss of capability to perform their safety function. The seismic anchorage responses for the supports of the SSCs can be obtained by static analysis. The input seismic accelerations at the anchor points shall be obtained by the dynamic analysis or from UBC.

EPRI NP-5228-M provides anchorage design guidelines. The load path shall be evaluated for stiffness, strength and prying action. For redundancy, more than one fastener must be used for each anchor point. the minimum size of the anchor shall not be smaller than $1 / 2$-inch diameter bolts except for office equipment tie-down, such as bookcases and computers.

\subsubsection{Quality Assurance}

The safety-related SSCs must be designed utilizing a formal quality assurance (QA) plan as required by DOE Order $5700.6 \mathrm{C}$. The QA and peer review should be conducted within the framework of a graded approach with increasing level of rigor employed from PC-1 to PC-4. The qualification of the peer reviewers shall comply with the provisions in DOE-STD 1020-94. The quality assurance process puts emphasis on the independent peer review and the qualification of the peer reviewers in seismic design.

\subsubsection{Wind}

This chapter provides the wind design criteria to ensure that the facility is designed to mitigate wind damage. It is known that the NRC design basis wind speeds are more conservative than 
those given in DOE-STD 1020-94, but, it is not clear that the missile criteria is true. Criteria for both agencies are given below and the design engineers should apply accordingly.

\subsubsection{Wind loading specification}

DOE Design Basis Wind (DBW) loads and wind-borne missiles impact parameters were developed to achieve the intended probabilistic performance goals. They are developed to be uniformly applicable to straight wind, tornado, and hurricane. The straight wind includes the storm wind and hurricanes.

The $\mathrm{P}_{\mathrm{H}} \mathrm{s}$ are given for $\mathrm{PC}-4$ and $\mathrm{PC}-3$ facilities for straight (extreme) wind and for tornado design separately. The PGs for tornado are much lower than those for the straight wind. The PC-2 and PC-1 facilities are not required to design for tornado.

The basic wind speed shall be derived from DOE site-specific hazard model studies summarized in DOE-STD 1020-94. If site-specific hazard model studies are not available, a site-specific wind hazard assessment shall be developed by a probabilistic wind hazard assessment for the facility. If the tornado $\mathrm{P}_{\mathrm{H}}$ at the intersection is greater than or equal to $2 \times 10^{-5}$, tornadoes are a viable threat at the site. If the tornado $\mathrm{P}_{\mathrm{H}}$ at the intersection is less than $2 \times 10^{-5}$, straight wind controls the design.

$\mathrm{NRC}$ developed the wind criteria using a deterministic regionalization approach equivalent to an annual safety goal of $1 \times 10^{-7}$ which is more stringent than the DOE wind hazard level of $1 \times 10^{-6}$ for a reactor. NRC wind design criteria are provided in the Regulatory Guide 1.76 which divides the contiguous United State into three tornado zones provided with maximum wind speed for the design basis tornado (DBT). A position paper was issued (March 25, 1988, Project No. 669) by the office of NRC to reduce the design criteria for the design basis for a ALWR providing lower DBW speeds for four zones.

Wind-borne missile impact design criteria are provided in Regulatory Guide 1.117 and the NRC Standard Review Plan, Section 3.5.1.4. The region where the selected site is located determines the DBT wind speed and velocity of the wind-borne missiles.

Wind-borne missile source is site-specific. Evaluation shall be performed to identify any sitespecific wind-borne missiles that may not be included in NRC or DOE provisions.

\subsubsection{Design procedures for wind responses evaluation}

The design procedures for wind responses evaluation are common to both the DOE and NRC criteria. The elastic wind responses of a facility shall be estimated dynamic or static analyses. The wind design procedures shall be in compliance with the provisions in the ASCE 7-86 which was previously ANSI A58.1.

The size of the wall opening shall be protected by tornado barrier. Small size openings without tornado barriers shall be justified by a probability of penetration by a steel pipe-type missile.

The responses from wind pressure, atmospheric pressure change (APC) due to tornado, and missile impact shall be calculated separately and combined with proper load factors in compliance with ASCE 7-86. The overall responses on the building wall and local responses on the tornado barriers from a missile impact shall also be computed and combined. 
The combined wind responses shall be combined with the non-wind responses for structural integrity evaluation. Note the seismic and wind responses are mutually exclusive in load combinations.

\subsubsection{Design detailing}

The major wind resisting structural members must be able to resist the wind loads without collapse or excessive deformation. The connections between the major structural members should be properly designed to ensure load transfer.

The piping attached to the exterior of a building and the equipment rested in the roof are subjected to strong wind and missile impact. Similar to earthquake design the anchorage of the piping and equipment is the cause of the avoidable damage. In addition they can become windborne missile causing more damage to other piping and equipment. The anchorage shall be designed to withstand the wind loads without loss of capability to perform the safety functions or becoming a wind-borne missiles.

The exposed equipment and components shall be protected by barriers. Additional design consideration is needed for the protection of stacks, diesel exhausts, water pumps, and fuel tanks.

\subsubsection{Quality assurance}

Peer review shall be conducted in compliance with the provisions given in Section 2.2.1.4 The quality assurance process puts emphasis on the independent peer review and the qualification of the peer reviewers in wind and tornado design.

\subsubsection{Floods}

This chapter provides the flood design criteria to ensure that the facility is designed to mitigate the flood damage. The strategy of the flood design is to situate the SSCs above the design basis floor level, to modify the flood, to harden the site or SSCs, and to establish emergency operation plans.

\subsubsection{Flood loading specification}

The flood $\mathrm{P}_{\mathrm{H}} \mathrm{s}$ are provided in the DOE-STD 1020-94. The design basis floods (DBFLs) corresponding to the $\mathrm{P}_{\mathrm{H}} \mathrm{s}$ for the DOE sites are not available. Site-specific probabilistic flood assessment is required for the PC-4, PC-3, and PC-2 facilities. Flood insurance studies or equivalent input is required for the $\mathrm{PC}-1$ facility.

The DBFL for a SSC is defined in terms of peak-hazard level (e.g. flow rate, water elevation) and corresponding loads associated with DBFL peak-hazard level (e.g. hydrostatic, hydrodynamic forces, debris impact loads). In calculating design loads from flooding, a conservative approach shall be taken to ensure that the loads used in the design are greater than the maximum historic levels recorded for the site and no less than the probable maximum flood.

Regulatory Guide 1.59 specifies two NRC flood design positions one of which is to design the Seismic Category I SSCs to withstand the worst site-related flood and retain capability for cold shutdown and maintenance. The other position is to designing hardened protection. The design basis flood should be developed with the consideration of the flood conditions induced by 
precipitation, streams, lakes or seashore, and earthquakes. The Appendix B of Regulatory Guide 1.59 gives timesaving alternative methods of estimating the probable maximum flood along streams and Appendix $\mathrm{C}$ provides simplified method of estimating probable maximum surges on the Atlantic and Gulf coasts. NRC Standard Review Plan, Section 2.4.3 provides procedures for evaluation of flood on streams and site drainage.

\subsubsection{Design procedures for flood responses evaluation}

The flood evaluation process as shown in the DOE-STD 1020-94 involves the consideration of regional flood hazards and local precipitation. The SSCs shall be situated above the DBFL water elevation. The design of the site stormwater management system and structural systems for local precipitation must be adequate to prevent flooding. DOE Order $6430.1 \mathrm{~A}$ provides the stormwater runoff for the design of roof drainage, subsurface drainage systems, street drainage, and open channels.

Regulatory Guide 1.102 provides three flood protection methods, namely: to maintain a dry site by building above the DBFL, to provide engineered protection features external to the immediate plant area, and to provide engineering protection features in the structural/environment interface. $\mathrm{NRC}$ also suggests to provide sufficient warning time to bring the plant to a safe shutdown condition.

Water elevation from the streams and runoff discharge shall be determined for site and local drainage systems layout and design. Flood rising level and time induced by stormwind or hurricane to streams, lakes, and seashore should be determined for flow rerouting or barrier building action planning. Shutdown technical procedures and emergency operating procedures are also necessary to be established.

Wind generated wave action will be estimated using Corps of Engineers criteria. Site drainage must comply with the regulations of the governing local agency. The minimum design level of the storm drainage is the 25-year, 6-hour storm, for subsurface and open channel design. For potential effects of larger storms should be up to 100-year, 6-hour storm. Watershed size over 160 acres is not allowed to use the Rational method for discharge calculation.

\subsubsection{Design detailing}

In the design of wave barriers, the dynamic and static structural effect shall be considered. In design of site drainage, open channel of one size larger than designed size should be used to account for the uncertainty of the vegetation lining of the channel and blockage built-up at the head wall. The roof drainage design shall prevent undesirable buildup of standing water on the roofs of the safety-related SSCs.

\subsubsection{Quality Assurance}

Peer review shall be conducted in compliance with the provisions given in Section 2.2.1.4 The quality assurance process puts emphasis on the independent peer review and the qualification of the peer reviewers in flood design. 


\subsubsection{Fire Protection}

The fire protection features for the plant and its associated support buildings will be in accordance with DOE Orders, the National Fire Protection Association (NFPA) Fire Codes and Standards, and NRC regulations and guidelines.

Redundant firewater supplies and pumping capabilities (electric motor drivers with diesel backup) will be installed to supply the automatic and manual fire protection systems located throughout the site. One supply and one set of pumps will be designed to meet Design Basis Earthquake (DBE) requirements. Appropriate types of fire protection systems will be installed to provide life safety, prevent large-loss fires, prevent production delay, ensure that fire does not cause an unacceptable on-site or off-site release of hazardous material that will threaten the public health and safety or the environment, and minimize the potential for the occurrence of a fire and related perils.

A fire hazards analysis will be performed to assess the risk from fire within the individual fire areas of the facility.

All fire sprinkler water that has been discharged in process areas during and after a fire will be contained, monitored, sampled, and, if required, retained until it can be appropriately treated and disposed of.

\subsubsection{Safety Class Instrumentation and Control}

The instrumentation and control systems important to safety in Advanced Light Water Reactors fall into the following categories.

Protection Systems. The instrumentation and control systems which initiate safety actions to mitigate the consequences of design basis events.

Engineered Safety Features (ESF) Control Systems. The control systems which regulate the operation of ESF systems following their initiation by the protection system.

Safe Shutdown Systems. The systems which must function to achieve and maintain a safe shutdown condition of the plant. The safe shutdown systems include those instrumentation and control systems which are used to maintain the reactor core in a subcritical condition and provide adequate core cooling to achieve and maintain both hot and cold shutdown conditions.

Interlock Systems Important to Safety. The systems which operate to reduce the probability of occurrence of specific events or to maintain safety systems in a state to assure their availability in an accident. These systems differ from protection systems in that their safety action is taken prior to or to prevent accidents.

Information Systems Important to Safety. The systems which provide information for the safe operation of the plant during normal operation, anticipated operational occurrences, and accidents. The information systems important to safety include those systems which provide information for manual initiation and control of safety systems, to indicate that plant safety functions are being accomplished, and to provide information from which appropriate actions can be taken to mitigate the consequences of anticipated operational occurrences and accidents. 
During normal plant operation, the information systems important to safety provide information on the bypassed and inoperable status of safety systems.

Control Systems. The systems used for normal operation that are not relied upon to perform safety functions following anticipated operational occurrences of accidents, but which control plant processes having a significant impact on plant safety.

Diverse Actuation Systems. The systems provided expressly for diverse backup of the reactor protection system and engineered safety features actuation systems. Diverse Actuation Systems account for the possibility of common mode failures in the protection systems. Diverse Actuation Systems include the Anticipated Transient Without Scram (ATWS) System. For plants with digital computer based instrumentation and controls, Diverse Actuation Systems also include hardwired manual controls and any other systems specifically installed to meet the guidance of NRC Notice SECY-93-087.

Data Communication Systems. The systems which transmit multiplexed digital signals between systems and between components of systems. Where such systems are included in a design they support one or more of the systems described above.

Other instrumentation and control systems important to safety may be included as an integral part of other safety critical systems such as fire protection, fuel handling, radiation monitoring, and control of essential auxiliary supporting systems. These instrumentation and control functions are typically treated as an integral part of the mechanical system.

For NRC licensed facilities, the General Design Criteria (GDC), 10CFR50 Appendix A, and IEEE Standard 279 establish minimum requirements for the design of nuclear power plants. These criteria establish the necessary design, fabrication, construction, testing, and performance requirements for structures, systems, and components important to safety. The structures, systems, and components important to safety are those that provide reasonable assurance that the facility can be operated without undue risk to the health and safety of the public.

A new standard, IEEE Standard 603, has been issued to replace IEEE Standard 279, but this standard has not replaced IEEE Standard 279 in the regulations. The requirements and recommendations of IEEE-603, as modified by Regulatory Guide 1.153, incorporate the requirements and recommendations of IEEE Standard 279. Therefore, compliance with IEEE Standard 603, as modified, is desirable and results in compliance with IEEE 279.

Other ALWR electrical systems important to safety fall into the following categories.

Offsite Power System. The preferred power system for the plant. This system must be sufficiently reliable to minimize challenges to the onsite emergency power systems.

Onsite AC Power Systems. The systems that distribute AC electrical power to normal, important to safety, and safety loads in the plant. The safety related loads include safety related HVAC, cooling water, instrument power, and emergency core cooling systems, and vital instrumentation. Onsite $\mathrm{AC}$ power systems include safety related emergency generators sufficient to power engineered safety feature loads in the event normal power supplies are lost. The onsite AC system also provides uninterruptable AC power to critical instrumentation loads. 
Onsite DC Power Systems. The systems that provide uninterruptable DC power to safety related DC loads. These loads include power circuit breaker controls, valves, instrumentation, and the uninterruptable $\mathrm{AC}$ power supply.

The electrical systems must meet the requirements of Criterion 17 of 10CFR50 Appendix A.

\subsubsection{Ventilation}

The heating, ventilating, and air conditioning (HVAC) system design will meet all general design requirements in accordance with DOE Order 6430.1A, and the guides of the American Society of Heating, Refrigerating, and Air Conditioning Engineers (ASHRAE).

The HVAC system provides environmental conditions for the health and comfort of personnel and for equipment protection. Typically, the ventilation system will be designed to maintain confinement to preclude the spread of airborne radioactive particulates or hazardous chemicals within the facilities and to the outside environment. 


\section{References - General}

1. Study of Plutonium Disposition Using the GE Advanced Boiling Water Reactor (ABWR), General Electric Company, GE Nuclear Energy, Report NEDO-32351 (April 1994)

2. DOE Plutonium Disposition Study - Screening Study for Evaluation of the Potential for the System 80+ to Consume Excess Plutonium, Combustion Engineering, Inc., DOE Contract No. DE-AC03-93 SF19682 (April 1994)

3. PDR Plutonium Disposition Study Phase II Final Report, Westinghouse Electric Company, DOE Contract DE-AC03-93 SF19683 (April 1994)

4. B.B. Bevard, et al., Reactor Facility Response to the FMDP LWR Alternative Data Call, Oak Ridge National Laboratory, Report ORNL/MD/LTR-27 (July 1995)

\section{References - Natural Phenomena Hazards}

DOE Order 6430.1A, General Design Criteria, U.S. Department of Energy, Washington, D.C. (June 1989).

DOE Order 5480.30, Nuclear Reactor Safety Design Criteria, U.S. Department of Energy, Washington, D.C. (January 1993).

DOE Order 5480.28, Natural Phenomena Hazards Mitigation, U.S. Department of Energy, Washington, D.C. (January 1993).

DOE-STD 1027-92, Hazards Categorization and Accident Analysis Techniques for Compliance with DOE Order 5480.23, Nuclear Safety Analysis Reports, U.S. Department of Energy, Washington, D.C. (December 1992).

DOE Order 5480.23, Nuclear Safety Analysis Reports, U.S. Department of Energy, Washington, D.C. (April 1992).

DOE-STD 1020-94, Natural Phenomena Hazards Design and Evaluation Criteria for Department of Energy Facilities, U.S. Department of Energy, Washington, D.C. (July 1994).

UBC, Uniform Building Codes, International Conference of Building Officials, Whittier, CA (1994). 
DOE-STD 1021-93, Natural Phenomena Hazards Performance Categorization Guidelines for Structures, Systems, and Components, U.S. Department of Energy, Washington, D.C.

(July 1993).

DOE-STD 1022-94, Natural Phenomena Hazards Site Characterization Criteria, U.S. Department of Energy, Washington, D.C. (March 1994).

DOE-STD 1023-94, Natural Phenomena Hazards Assessment Criteria, U.S. Department of Energy, Washington, D.C. (January 1994).

DOE-STD 1024-92, Guidelines for Use of Probabilistic Seismic Hazard Curves at Department of Energy Sites, U.S. Department of Energy, Washington, D.C. (December 1992).

ASCE Standard 4-86, Seismic Analysis of Safety-Related Nuclear Structures and Commentary on Standard for Seismic Analysis of Safety Related Nuclear Structures, American Society of Civil Engineers, New York, New York (September 1986).

ASCE Standard 7-88, Minimum Design Loads for Buildings and Other Structures (September 1988). Revision of ANSI A58.1-1982, American Society of Civil Engineers, New York, New York.

10 CFR 50, Code of Federal Regulations, Domestic Licensing of Production and Utilization Facilities, the Office of the Federal Register National Archives and Records Administration (January 1994).

10 CFR 100, Code of Federal Regulations, Reactor Site Criteria, the Office of the Federal Register National Archives and Records Administration (January 1994).

ACI 349-85, Code Requirements for Nuclear Safety Related Concrete Structures and Commentary, American Concrete Institute, Detroit, Michigan (March 1986).

ANSUANS-52.1, Nuclear Safety Criteria for the Design of Stationary Boiling Water Reactor Plants, American National Standards Institute/American Nuclear Society, La Grange Park, Illinois (1983).

Regulatory Guide 1.26, Quality Group Classifications and Standards for Water-, Steam-, and Radioactive-Waste-Containing Components of Nuclear Power Plants, U.S. Nuclear Regulatory Commission Regulatory Guide, Office of Nuclear Reactor Regulation, Washington, D.C. (February 1976).

NUREG-0800, U.S. Nuclear Regulatory Commission Standard Review Plan, Office of Nuclear Reactor Regulation, Washington, D.C. 
Regulatory Guide 1.29, Seismic Design Classification, U.S. Nuclear Regulatory Commission Regulation Guide, Office of Nuclear Reactor Regulation, Washington, D.C. (February 1978).

Regulatory Guide 1.60, Design Response Spectra for Seismic Design of Nuclear Power Plants, U.S. Nuclear Regulatory Commission Regulation Guide, Office of Nuclear Reactor Regulation, Washington, D.C. (February 1973).

Regulatory Guide 1.61, Damping Values for Seismic Design of Nuclear Power Plants, U.S. Nuclear Regulatory Commission Regulation Guide, Office of Nuclear Reactor Regulation, Washington, D.C. (October 1973).

Regulatory Guide 1.76, Design Basis Tornado for Nuclear Power Plants, U.S. Nuclear Regulatory Commission Regulation Guide, Office of Nuclear Reactor Regulation, Washington, D.C. (April 1974).

Memorandum from L.S. Rubenstein, Director of Standardization and Non-Power Reactor Project Directorate, NRC Office of Nuclear Reactor Regulation, to E.E. Kintner, Chairman of ALWR Utility Steering Committee, GPU Nuclear Corporation, on the subject "ALWR Design Basis Tornado" (March 1988).

Regulatory Guide 1.59, Design Basis for Flood for Nuclear Power Plants, U.S. Nuclear Regulatory Commission Regulation Guide, Office of Nuclear Reactor Regulation, Washington, D.C. (August 1974).

Regulatory Guide 1.102, Flood Protection for Nuclear Power Plants, U.S. Nuclear Regulatory Commission Regulation Guide, Office of Nuclear Reactor Regulation, Washington, D.C. (September 1976).

EPRI NP-5228-M, Seismic Verification of Nuclear Plant Equipment Anchorage, Rev. 1, for Electric Power Research Institute, URS/John A. Blume \& Associates, Engineers, San Francisco, CA, June.

EPRI, Advanced Light Water Reactor Requirements Document, Volume 1, ALWR Policy and Summary of Top-Tier Requirements, Final Draft for Review, Electric Power Research Institute, Palo Alto, California (issued January 1990). 


\subsection{SITE MAP AND LAND USE REQUIREMENTS}

\subsection{Site Map}

Figs. 3-1 through 3-3 show ALWR site maps for the BWR, large PWR, and small PWR facilities, respectively. The size, number, and arrangement of facility buildings is, in all cases, conceptual and can change significantly as the design progresses. These site plans convey general layout information only.

\subsection{Land Area Requirements During Operation}

Total land area requirements during operation for the large ALWR facility (two units) would be approximately 340 acres; increasing the facility to four units would increase the total disturbed land area during operation to approximately 560 acres. ${ }^{1}$ These figures assume an away-from-reactor MOX fuel fabrication facility and are also assumed to apply as a first approximation for the two-unit small ALWR facility. Co-location of a fuel fabrication facility with the reactor facility (large or small) would add approximately 50 acres to the total land area requirements, although this figure might be reduced somewhat by sharing of certain general facilities (e.g., security, fire protection). ${ }^{2}$

\subsection{Land Area Requirements During Construction}

Based on single-unit figures provided in the ALWR Tritium Supply Plant data report, total land area requirements during construction for a two-unit ALWR plant (large or small) are estimated to be approximately 700 acres. ${ }^{3}$ This includes the area required for laydown, warehousing, parking, on-site fabrication, modular construction assembly, and concrete batch plant.

${ }^{1}$ DOE Plutonium Disposition Study - Pu Consumption in ALWRs, ABB Combustion Engineering, Contract No. DE-AC03-93 SF19862 (May 1993).

${ }^{2}$ DOE Plutonium Disposition Study - Screening Study for Evaluation of the Potential for the System 80-10 Consume Excess Plutonium, Combustion Engineering, Inc., DOE Contract No. DE-AC03-93 SF19682 (April 1994 ).

${ }^{3}$ Data Report on Advanced Light Water Reactor Tritium Supply Plant, Advanced Technology Business Unit, Fluor Daniel, Inc., DOE Contract DE-AC05-910R21964 (September 1994). 


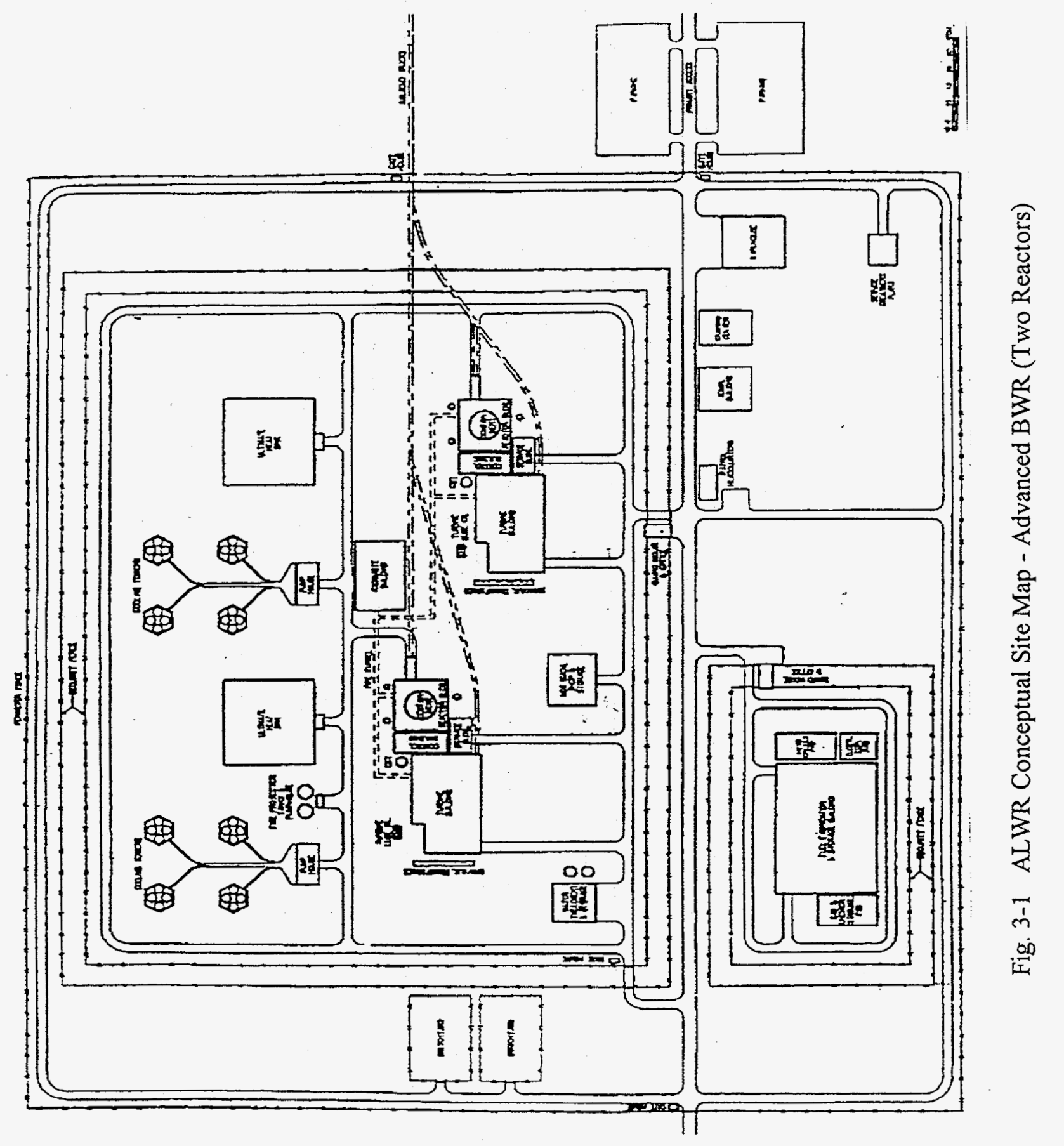




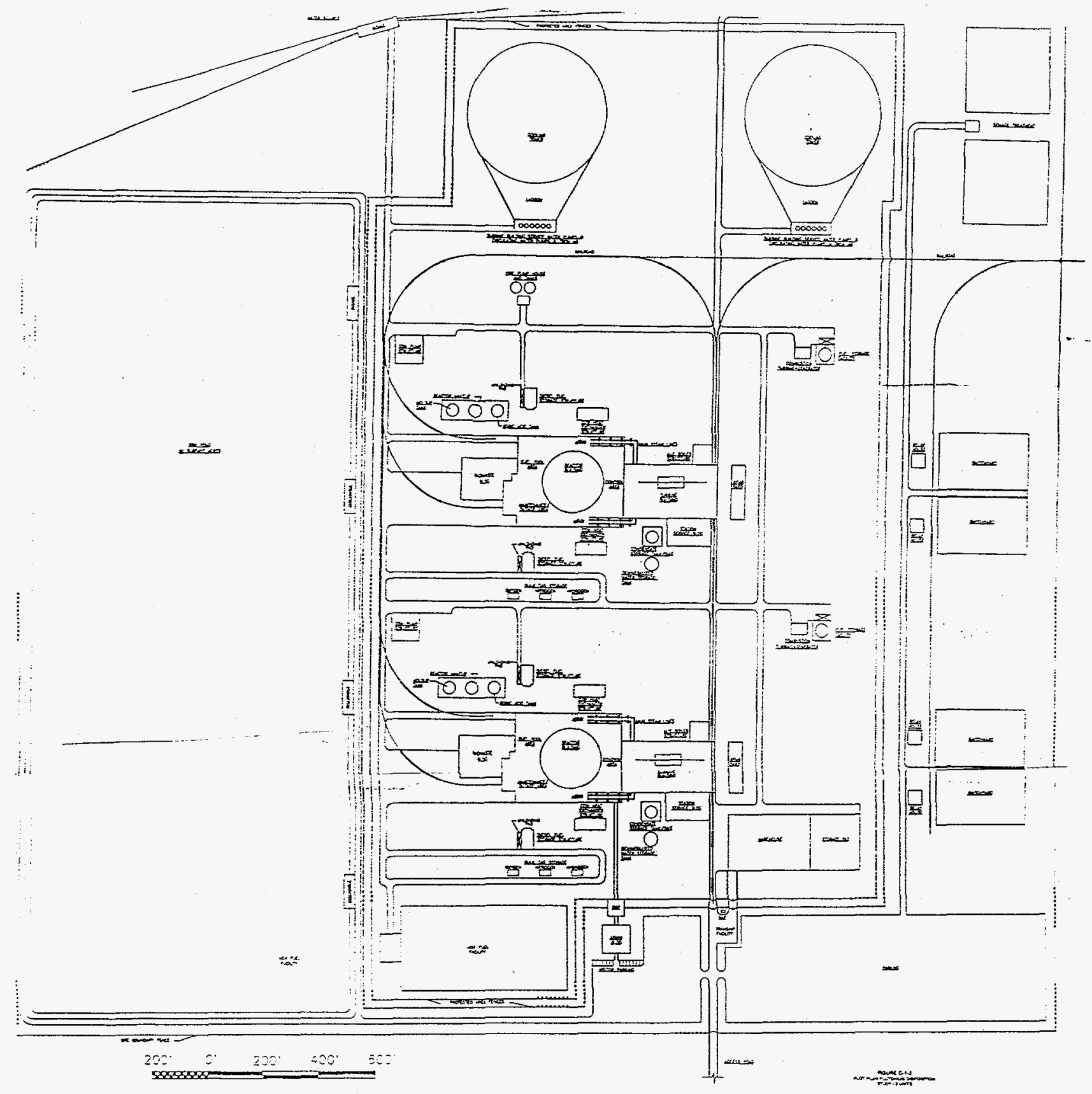

Fig. 3-2 ALWR Conceptual Site Map - Large PWR 


\section{PDR 600 Twin Unit Site Plan}

\section{LEGENO}

1. Reactor Containment Buildings

2. Turbine Buildings

3. Annex / Building

4. Annex || Buildings

5. Fuel Handling Buildings

6. Auxiliary Buildings

7. Access Control Buitding

8. Gatehouse

9. Warehouse

10. Transformer Areas

11. Security Control Building

12. Diesel Generator Buildings

13. Solid Radwaste Buildings

14. Fire Pump Houses

15. Chlorination Buildings

16. Cooling Towers

17. Pump Basins

18. Radwaste Drumming Station

19. Futuro Evaporator Additional Space

20. Auxiliary Boiler

21. Shipping and Recoiving
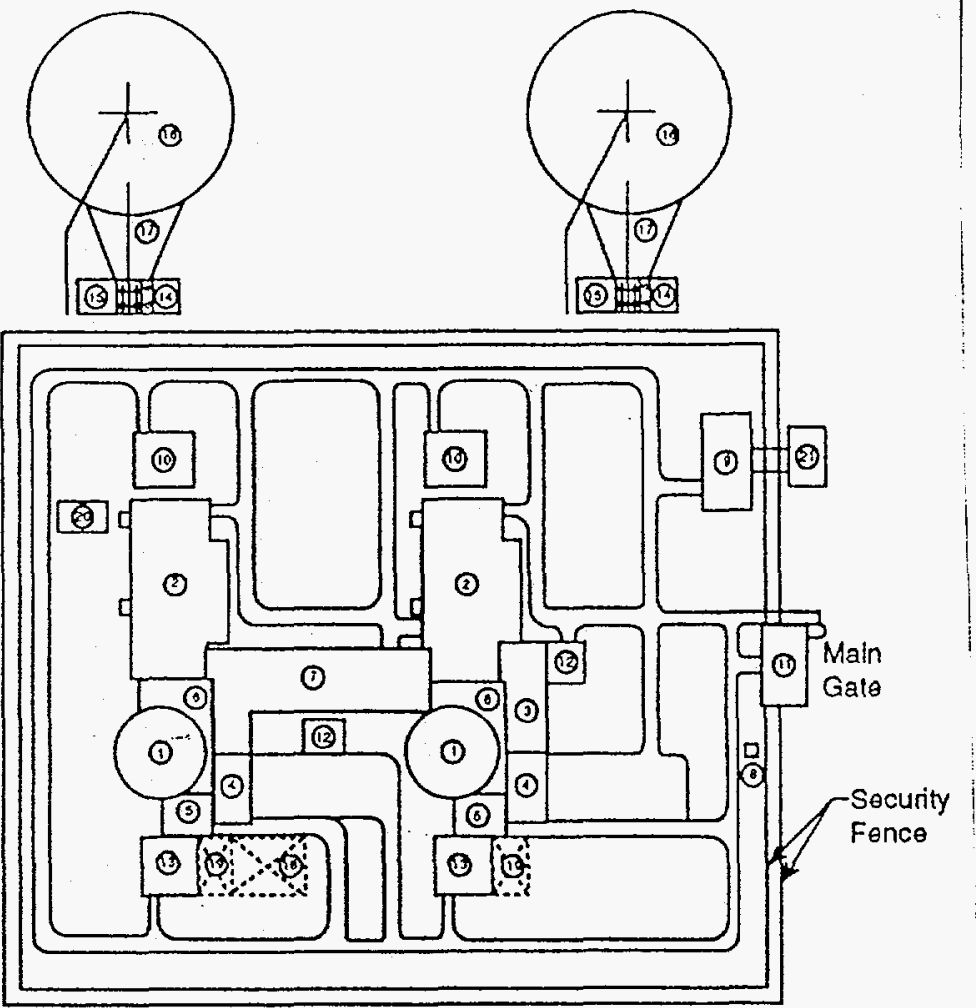

Fig. 3-3 ALWR Conceptual Site Map - Small PWR 


\subsection{PROCESS DESCRIPTION}

The environmental impact associated with each of the fission options is similar to those associated with existing LWRs. Improvements upon this are realized by burning plutonium, which decreases uranium mining, milling, and enrichment requirements and their associated waste. Although the various fission options differ in their effect on the latter factors, these differences were not quantified. The most significant difference between the fission options was found to be the difference in amount of high-level waste produced.

Three environmental issues were estimated:

1. TRU in Waste: The transuranic (TRU) mass in the waste.

2. Heat in Waste: The heat generated in the waste (10 years after discharge).

3. Resource Utilization: A measure of the electric energy that can be extracted from the use of Pu-239. This measure, the resource utilization factor, is based on the well-known approximation that fission of $1 \mathrm{~g}$ of $\mathrm{U}-235$ yields $1 \mathrm{Mwd}(\mathrm{t})$ of energy.

\subsection{Processes}

Radioactive wastes which appear directly during reactor operation are generally of two types. Fission products enter the coolant as a result of cladding leaks of failures. They consist primarily of noble gases, halogens, and tritium. The second waste constituent is activation products generated from neutron irradiation of the coolant and its additives. These wastes vary with the coolant.

\subsubsection{Noble Gases}

The chemically inert noble gases separate readily from liquid coolant (and any other medium). Since many of the constituent nuclides have short half-lives, the delay and decay principle is appropriate. Relatively large gas volumes, however, preclude long-term storage.

The most limiting problems with the noble gases are experienced in the BWR. Here, the single-loop, direct-cycle coolant releases the gases on a continuous basis as they enter the turbine. Limited storage-tank volumes require release after only one day of decay time. Gaseous-effluent restrictions require that the noble gases be discharged from a very tall stack.

The multiple-loop reactors employ the primary system as a "delay tank" for an initial period of time. Then the gases are "bled off" to storage tanks on a predetermined schedule. Such procedures allow the pressurized-water reactor [PWR], for example, to hold back noble-gas release by up to 60 days. The resulting 100-fold reduction in activity allows building-level dispersal.

\subsubsection{Tritium and Soluble Boron}

Tritium, the radioactive isotope of hydrogen, is produced by several mechanisms in operating reactors. It is readily incorporated with water molecules as $\mathrm{HTO}$ and very rarely as $\mathrm{T}_{2} \mathrm{O}$. Since isotopic concentration or separation is not feasible, this relatively long-lived $\left[\mathrm{T}_{1 / 2}=12.3\right.$ years $]$ radionuclide is subjected to the dilute and disperse procedure. 
A primary production mechanism for tritium is ternary [three-fragment] fission. Even the small amounts released through the clad to the coolant constitute an important waste management problem for all reactors. Additional tritium sources result from neutron absorption in deuterium or boron. The heavy-water CANDU system experiences large tritium production from the ${ }^{2} \mathrm{D}(\mathrm{n}, y)$ reaction. However, since most tritium will reside in the stationary moderator volume, essentially in-place storage is facilitated.

The use of soluble boron for reactivity control in the PWR has a double-edged effect on system wastes. Negative reactivity is readily inserted by adding a small amount of high-concentration boric acid to the coolant. A positive insertion, however, requires a general dilution of the coolant with a large volume of boron-free water. This latter situation, of course, produces a comparable amount of liquid waste that is contaminated with fission products, tritium, and other radionuclides. Special liquid waste tanks are built into PWR's just to handle boron dilution. The second complication is that the ${ }^{10} \mathrm{~B}(\mathrm{n}, 2 a)$ reaction in the soluble boron is responsible for the production of a substantial amount of extra tritium. Ultimately, the tritiated water must be diluted and discharged.

\subsubsection{Solid Wastes}

Solid radioactive wastes from reactor operations are generally associated with cleanup of gaseous and liquid waste streams or with testing and maintenance activities. The chemically reactive gases like the halogens are readily immobilized on filters. Elemental impurities (as opposed to isotopic impurities, e.g., HTO in $\mathrm{H}_{2} \mathrm{O}$ ) can often be removed to demineralizer resins. Other liquid wastes are concentrated or reduced to solids in an evaporator.

Testing and maintenance operations generated contaminated clothing, gloves, wipes, and tools. These and the filters, resins, and concentrates are packaged into steel drums like the fabrication wastes. Some liquids are mixed in concrete binder and placed in the same or different drums.

\subsubsection{Storage}

Interim spent-fuel storage produces a minimum amount of additional radioactive wastes (assuming leaking assemblies are packaged). From the time of reactor shut-down, the absence of new fission-product generation and lower thermal gradients limit general release from the fuel assemblies.

The spent fuel itself is the fuel cycle's final waste form if reprocessing is not to be implemented. Since the assemblies were not designed for an indefinite lifetime, extended water-basin storage may be expected to compromise their integrity.

\subsubsection{Liquid Wastes}

The separate fission-produce and actinide wastes leave the active processing in nitric acid solution. In their as-generated form, stainless-steel tanks are required for storage. Less expensive, mild-steel tanks may be employed if the solutions are made alkaline.

Following leakage problems with early tanks, current designs incorporate full double walls. They provide leak detection capability and opportunity for timely transfer of material to other tanks. 
The heat-loaded from the radioactive products necessitates use of forced cooling. Most tanks incorporate an extensive network of water piping for this purpose.

\subsubsection{Solidification}

Since liquids are subject to leakage and spills, it is desirable to convert spent-fuel wastes to a solid form. Current federal regulations call for:

- storage of commercial wastes in liquid form for no longer than 5 years from the time of separation

conversion to a solid form for on-site storage past 5 years

- transfer of solidified wastes to a federal repository no later than 10 years after separation

In the absence of commercial reprocessing and a federal repository, the regulations are academic. They do, however, serve as guidelines for technology development related to solidification, management, and ultimate disposal of wastes.

High-level liquid wastes from reprocessed LWR spent fuel contain fission products, residual uranium and plutonium, and other actinides. If separation follows 180 days of cooling, the wastes from each metric ton of uranium generate heat at a rate of $15-20 \mathrm{~kW}$ and occupy a volume of about 1200 liters. Prior to solidification (nominally at 5 years), the heat rate would be down to a few kilowatts and the volume could be reduced to about 600 liters.

\subsection{Process Diagrams}

\subsubsection{Radwaste Systems}

The system for the treatment of various radioactive liquids and gases prior to discharge to the environment is called the radwaste system. Its purpose is to reduce radioactivity levels in the plant effluents to such an extent that they will satisfy the regulations and guidelines of the U.S. Nuclear Regulatory Commission (NRC). Concentrations of radioactive nuclides in water and air at the nuclear plant boundaries must not exceed the values specified in Title 10 of the Code of Federal Regulations, Part 20 (10CFR20). Furthermore, radiation doses from effluents to people in unrestricted areas must be kept as low as is reasonably achievable (ALARA). The details of the radwaste systems vary from one reactor installation to another because of differences in local circumstances and preferences of the plant designer. The general descriptions given here, however, are applicable to all plants using reactors of the same type (i.e., PWR or BWR).

A radioactive liquid (i.e., water containing dissolved radioactive material) is commonly decontaminated, that is, it has its radioactivity decreased, in two different ways. One is by evaporation, in which the water is boiled off and the steam is condensed. Most of the radioactive material remains behind in the evaporation residue and is disposed of in a controlled manner. The condensed water is essentially (although not completely) free of dissolved solids, but it will contain nearly all of the tritium. The latter is largely present as tritiated water (HTO)-that is, $\left(\mathrm{H}_{2} \mathrm{O}\right)$ in which one atom of ordinary hydrogen $(\mathrm{H})$ has been replaced by a tritium $(\mathrm{T})$ atom. In the evaporator, the tritiated water is vaporized and subsequently condensed with the ordinary water. 
The second way of decontaminating a radioactive liquid is by means of demineralizer. The latter contains what is known as an ion-exchange resin, similar to the material often used in household (and industrial) water softeners. When a radioactive solution is passed through the demineralizer, the resins removes and retains much of the dissolved matter. The elements cesium, yttrium, and molybdenum are removed relatively slowly by demineralizers, and tritium is essentially unaffected.

As a general rule, demineralization, although less effective than evaporation, is the preferred decontamination procedure because of its simplicity. However, if the total amount of dissolved solids, both radioactive and nonradioactive, is moderately large (or quite large), the ion-exchange resin would soon become saturated and would have to be regenerated or replaced frequently. Evaporation is then the preferred process. In some situations, where considerable decontamination is to be achieved, both procedures may be used, with evaporation generally preceding demineralization.

The gaseous effluent from a nuclear power plant contains the noble gases (i.e., krypton and xenon), iodine, and particulate matter. The particulate matter is decreased by passing the gas through a high-efficiency particulate air (HEPA) filter prior to discharge, and part of the iodine is removed by a charcoal (or other) filter. The noble gases are difficult to remove, and so they are held up for a time to permit the activity to decrease by natural radioactive decay.

\subsubsection{Liquid Wastes from a PWR Plant}

Chemical and Volume Control System. The chemical and volume control system (or CVCS) of a PWR power plant is not strictly part of the radwaste system, but it plays a role in decreasing the amount of radioactivity in the liquid effluent. The CVCS consists of two subsystems: namely, the reactor coolant water cleanup subsystem and the boron recovery subsystem (Fig. 4.1). A bypass in the main (primary) coolant circuit permits some of the reactor water to be diverted continuously through the cleanup (i.e., purification) subsystem. The water is cooled and passed through a demineralizer to remove dissolved substances, including fission and activation products (but not boric acid), before being filtered and returned to the coolant circuit. Most of the radioactivity is thus retained by the ion-exchange resin in the demineralizer.

During the course of the operation of a PWR, the concentration of the boric acid used for shim control must be decreased. In the early stages, some of the purified water from the cleanup subsystem is withdrawn periodically for removal of boric acid in the boron recovery subsystem. The water is evaporated, and the steam is condensed; the condensate, essentially free from boron, is then returned to the primary circuit. The boric acid remains in the evaporator as concentrated solution, which is drawn off-periodically and stored for reuse as required.

When there is an accumulation of radioactive material in the boric acid residues, they are disposed of with solid wastes. In the later stages of the core lifetime, the concentration of boric acid in the primary coolant circuit is fairly low, and evaporation for boron recovery is not economical. A special deborating demineralizer is then included in the reactor coolant cleanup sub-system to decrease the boron concentration.

Clean and Dirty Wastes. In most PWR facilities, the liquid wastes are divided into three main categories: (a) clean wastes, (b) dirty wastes, and (c) laundry wastes. The terms clean and dirty 
as used here refer to the chemical purity of the water and not to the amounts of radioactivity. The clean wastes, also called primary system wastes, originate in the primary coolant circuit and have the highest level of radioactivity of all the liquid wastes. Apart from the radioactivity, however, the water is exceptionally pure.

The clean wastes are made up of excess water from the CVCS, pump-seal and valve leakages, and any other liquids that may have leaked or been released from the primary coolant system. The liquids are collected in a tank where they are held for several (up to 30) days to permit radionuclides of short half-life to decay. The contents of the tank are filtered and then decontaminated by evaporation or demineralization or both. Part of the decontaminated water is retained for use as primary coolant. After being tested for radioactivity, the remainder is diluted with clean water (e.g., from the turbine condenser) and discharged at a controlled rate into an adjacent water body (Fig. 4.2). When the condenser water is recirculated through a cooling tower, only a small volume is available for dilution purposes. Additional decontamination of the effluent might then be required prior to discharge. ${ }^{1}$

Laundry wastes consist mainly of water from the plant laundry, where protective clothing is washed, and from showers. Because of the presence of detergents, which might interfere with the operation of demineralizers and evaporators, the relatively small volume of laundry wastes is kept separate from other wastes. Since the radioactivity level is low, the water is stored fro a time in a holdup tank, filtered, mixed with clean water, and discharged after testing.

Steam Generator Blowdown. As the PWR plant operates, the concentration of salts in the secondary system water gradually increases; this can occur as a result of the presence of normal impurities in the water, of leakage from primary to secondary in the steam generator, and especially of leakage of cooling water through defective tubes in the condenser. To prevent the buildup of solids on the stream generator tubing, which would decrease the operating efficiency, water is withdrawn at a rate of about 38 liters $(10 \mathrm{gal}) / \mathrm{min}$ from the secondary (or steam) side of the generator and replaced by fresh water. The withdrawn water (or blowdown) enters a flash tank at a lower pressure where about half flashes into steam. If the steam generators are completely free from internal leaks, there is no radioactivity in the blowdown. Both liquid water and steam can be discharged without further treatment.

In practice, however, small holes develop in the miles of tubing in the steam generators; radioactive material in the primary coolant can leak into the secondary system and thus appear in the blowdown. In the earlier PWRs, the blowdown water was discharged after mixing with uncontaminated condenser water, but in later plants the water is either treated along with the

\footnotetext{
${ }^{1}$ In the dirty liquid wastes, the water is not originally of reactor quality, but its radioactivity is relatively low. These wastes include liquids from various floor drains and sumps, laboratory drains, and from cleanup areas. The wastes are collected in a holding tank and filtered; if the radioactivity level is low enough, the liquid may be diluted and discharged. Otherwise, the dirty wastes may be decontaminated by evaporation (and possibly by demineralization) before discharge. In some cases, the dirty wastes are mixed with clean (primary) wastes and decontaminated.
} 
clean wastes or demineralized separately before discharge. In some PWR installations blowdown is avoided by using a cleanup demineralizer in a bypass of the secondary circuit.

With adequate decontamination, moderate leakage rates (e.g., up to about 76 liters [20 gal]/day) in the steam-generator tubing can be tolerated. If the leakage rate becomes too large, the faulty steam generator is shut down, and the leaks are plugged. High leakage rates not only mean that additional treatment is necessary to reduce the radioactivity level in the blowdown, but the boric acid from the primary coolant deposits as solid on the steam generator tubing and is difficult to remove.

\subsubsection{Gaseous Wastes from a PWR Plant}

Primary System Gases. Gaseous wastes from a PWR installation are conveniently considered as primary system gases, secondary system gases, and building ventilation gases (see Fig. 4.3): The primary system gases include fission product gases (and vapors) vented from the CVCS and from the liquid waste holdup tanks. In addition, hydrogen and nitrogen gases are present for the following reasons. As a result of the intense neutron and gamma radiation within and near the reactor core, water may be decomposed into its component gases, hydrogen and oxygen. In a PWR this decomposition, called radiolysis, is suppressed by the deliberate addition of a certain amount of hydrogen gas to the primary coolant water. Furthermore, nitrogen gas is commonly used to purge (i.e., to remove) the air from the reactor vessel in order to avoid the possibility of forming an explosive mixture of hydrogen and atmospheric oxygen.

In may PWRs, the primary system gases are collected in a storage tank and compressed into one of several decay tanks where the gases are held for a period of about 60 days, on the average (Fig. 4.4). The only radioactive species remaining in appreciable amount are then krypton-85, xenon-133, iodine-131, and tritium. These residual gases are passed through filters to remove particulate matter and then mixed with large volumes of filtered ventilation air before discharge through a roof vent or stack. In more recent PWR plants the volume of primary waste gas is decreased by removing the hydrogen component. The gas is mixed with oxygen and passed through a catalytic recombiner; here the hydrogen and oxygen unite to form water.

Secondary System Gases. The secondary system gases are mainly

1. those released during steam generator blowdown

2. air ejector gases, which are removed continuously from the low-pressure (exhaust) side of the turbine by means of a steam jet

3. gland-seal effluent, consisting of steam used to seal the turbine glad and prevent the entry of air.

Radioactivity in the secondary waste gases would arise from leakage in the steam generator tubes. If there is little or no leakage, the radioactivity level will not be significant. The secondary gases may then be discharged without treatment after mixing with ventilation air. In many PWRs, however, only the gland-seal effluent is discharged in this way. After condensing the steam, the other gases are passed through charcoal to decrease the iodine content; they are then filtered to remove particulate matter and discharged with the ventilation air by way of a roof vent or stack. 
Ventilation Air. In the third category of gaseous wastes are the large volumes of ventilation air, most of which is from auxiliary buildings where the radioactivity level is very low. The air is often discharged directly after filtration, but in some plants charcoal is used to remove much of the iodine before discharge. Because of the low radioactivity level and large volume, the ventilation air is useful for reducing the concentrations of radionuclides in the other gaseous effluents.

The closed containment structure containing the reactor primary system is purged a few times a year with clean air. Before discharge with the other gases through the plant vent (or stack), the air is passed through charcoal and particulate filters. In some PWR installations the accumulation of radioactivity in the containment atmosphere between purges is decreased by circulating the air continuously through charcoal filters, called "kidneys," to remove iodine and through particulate filters to retain suspended solids.

\subsubsection{Solid Wastes from a PWR Plant}

The solid wastes from a PWR plant arise mainly from spent ion-exchange (demineralizer) resins, discarded filter material (including charcoal), and evaporator residues. The latter are often slurries rather than solids, but they are generally solidified by being mixed with cement (or cement and vermiculite). Solid wastes are enclosed in 55-gal steel drums and held in a shielded area for a few months to permit partial radioactive decay.

The drums are eventually shipped in accordance with U.S. Department of Transportation and NRC regulations to a state-licensed burial site. Such sites, to which access is severely restricted, were located near West Valley, New York; Morehead, Kentucky; Sheffield, Illinois; Richland, Washington; Beatty, Nevada; and Columbia, South Carolina. The sites in New York, Kentucky, and Illinois were closed down in 1979 and the others have restricted their operations. Because of the reluctance of licensed sites to accept radioactive wastes from other states, it is possible that the federal burial sites may have to be developed, especially for wastes from medical facilities. Solid wastes from nuclear power operations may have to be buried within the plant sites.

\subsubsection{Tritium Disposal from a PWR Plant}

Tritium presents a special problem in PWR radioactive waste disposal because substantial quantities of this radionuclide are formed in the primary coolant from neutron interaction with boron. As ready noted, the tritium, as tritiated water, becomes an integral part of the reactor water from which it is not separated by evaporation or demineralization. Some of the tritium is discharged with the gaseous effluents, but most remains in the PWR liquid waste. When ample volumes of water are available (e.g., from an adjacent river) to dilute the liquid waste and so reduce the concentration below the required limit, the tritium can be discharged at a controlled rate with the liquid effluent. Alternatively (or additionally), the water may be evaporated and the tritiated water vapor discharged to the atmosphere with the gaseous effluents.

In many modern PWR plants most of the decontaminated liquid waste is not discharged, but is reused in the primary system. There is eonsequently a steady buildup of tritium in the reactor water. Eventually, the concentration reaches a level at which it might represent a hazard to operators when the reactor vessel is open for refueling. Part of the water is then withdrawn for 
disposal. Presently, the water is mixed with cement (or other material), and the resulting solid is buried with other solid wastes.

Alternative methods of tritium disposal, which are being studied but have not yet been approved, are prolonged storage of the tritiated water in large tanks, injection into deep wells considerably below the levels accessible for human consumption, and discharge into the ocean, where extensive dilution would occur. Since the half-life of tritium is just over 12 years, about 90 percent decay will occur in 40 years.

\subsubsection{Comparison of PWR and BWR Wastes}

The radioactive wastes produced in a BWR power plant differ from those generated in a PWR for three main reasons. In the first place, BWRs do not use boric acid in the reactor water as a shim control; there is consequently much less tritium formed. Second, since steam is generated in the reactor vessel, radioactive gases (and vapors) that have escaped from defects in the fuel cladding or that were formed by neutron activation will be carried by the steam into the power conversion system.

\subsection{Waste Management}

Nuclear fuel cycle wastes may be classified according to their radiation and heat-generation levels, as well as their composition. The following working definitions serve as bases for further discussions:

- low-level wastes [LLW]-actinide content low enough $(\sim 10 \mathrm{nCi} / \mathrm{g})$ to permit disposal by surface burial

- contact-handled transuranic [TRU] wastes-actinide content $\sim 10 \mathrm{nCi} / \mathrm{g}$, minimal heat generation, surface dose rate low enough $(\sim 200 \mathrm{mrem} / \mathrm{h})$ to permit handling by contact (as opposed to remote) methods

- remote-handled transuranic [TRU] waste-actinide content $\sim 10 \mathrm{nCi} / \mathrm{g}$, some heat generation, surface dose rates high enough $(\sim 200 \mathrm{mrem} / \mathrm{h})$ to require remote handling and/or shielding.

- high-level wastes [HLW]-waste products from spent-fuel assemblies.

The drum-packaged wastes from reactor operation, and spent fuel storage are low-level wastes. Testing and maintenance activities also produce wastes of this type. They are generally stored on-site for a period of time before being shipped to designated sites for shallow burial.

The high-level wastes are a mixture of fission products and actinides. Spent fuel assemblies are in a solid form.

General waste management strategies consider both storage (e.g., interim, retrievable emplacement) and disposal (i.e., permanent, nonretrievable storage). Either may be applied to spent fuel. Fuel assemblies are likely to remain intact for interim storage and, assuming reprocessing is not permitted at a future date, will be the form for final disposal. 


\section{Storage}

In the absence of reprocessing, a "once-through" fuel cycle is said to exist. The spent fuel assemblies are first placed into interim storage, perhaps sequentially at different facilities. Ultimately, the intact assembly becomes the final disposal form.

The prospect of a once-through cycle prompted DOE to formulate a long-term policy calling for:

- the government to take ownership to spent fuel at approved storage sites

- the utility to pay the cost of transportation to the site and pay a one-time fee to cover both the interim storage and eventual permanent disposal (nominally several million dollars per year for a 1000-MWe plant)

- return of the spent fuel (or an equivalent credit) plus the unused portion of the storage and/or disposal fee if reprocessing becomes a viable option at a later time

Interim fuel storage options may be divided into two categories. Unpackaged assemblies are to be handled in essentially the manner now employed in storage pools at the reactor site. Various dry storage schemes have been proposed. Packaging of the assemblies allows for their isolation in one of several engineered or geologic facilities.

\section{Packaged Fuel}

Prolonged storage has not typically been an important fuel-assembly design criterion. Thus, viable long-term isolation is dependent on packaging in an appropriate container.

A facility for storing packaged spent fuel must provide for heat removal by active or passive means, criticality control by spacing and/or poisoning, monitoring, and equipment for handling operating wastes generated by corrosion and/or leakage. The ability to overpack and store leaking canisters is also important to the overall facility design. 


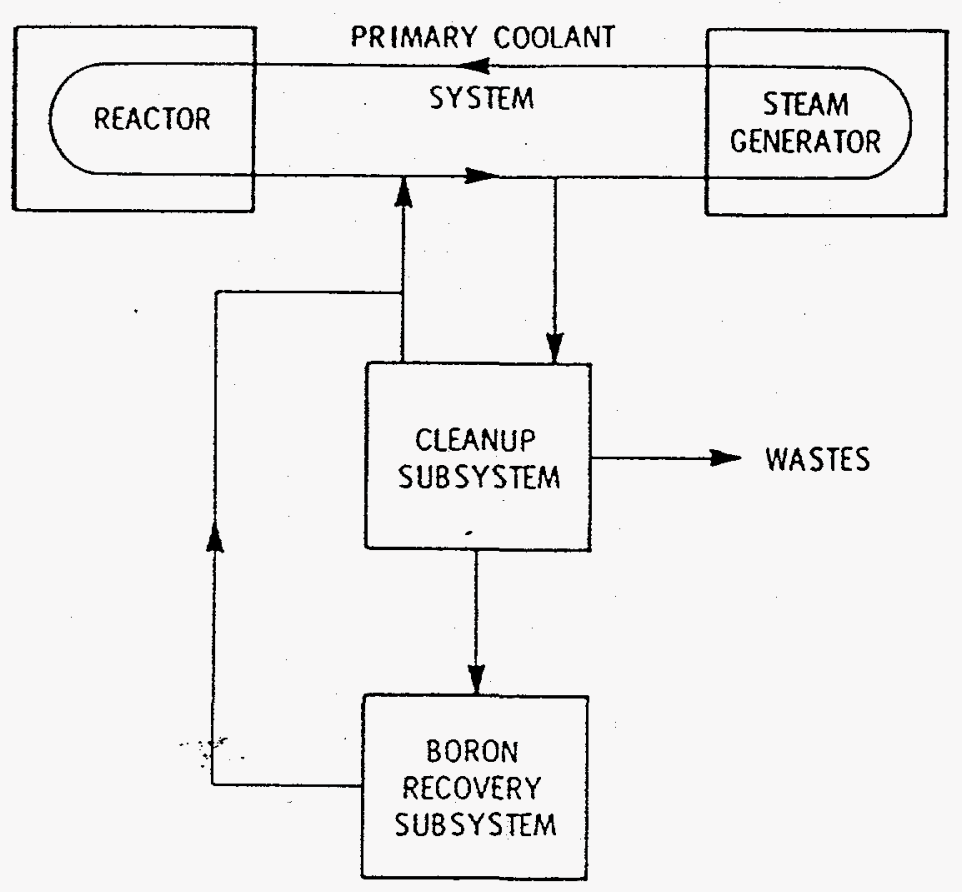

Fig. 4.1 Schematic diagram of a typical PWR chemical and volume control system.

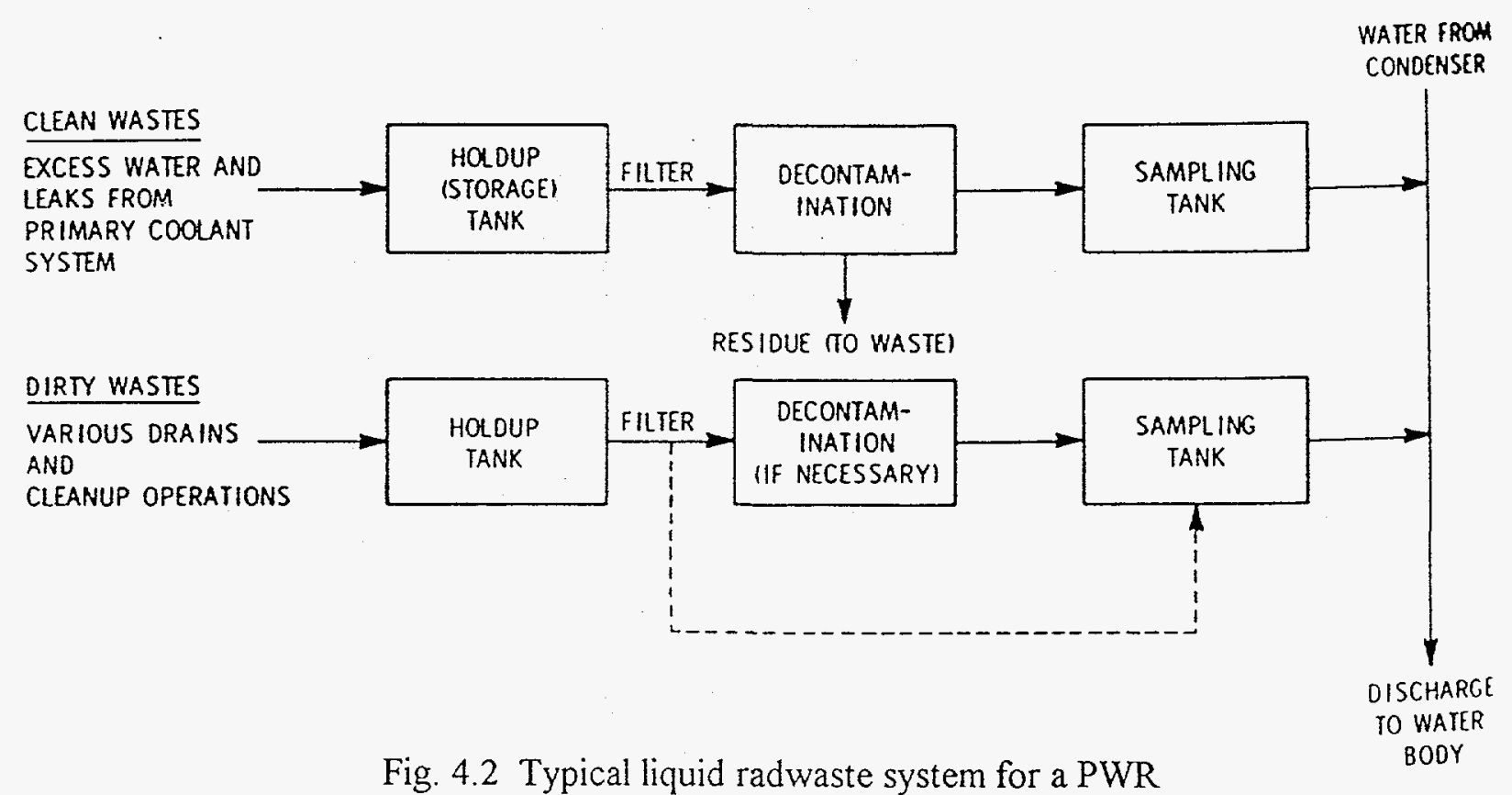




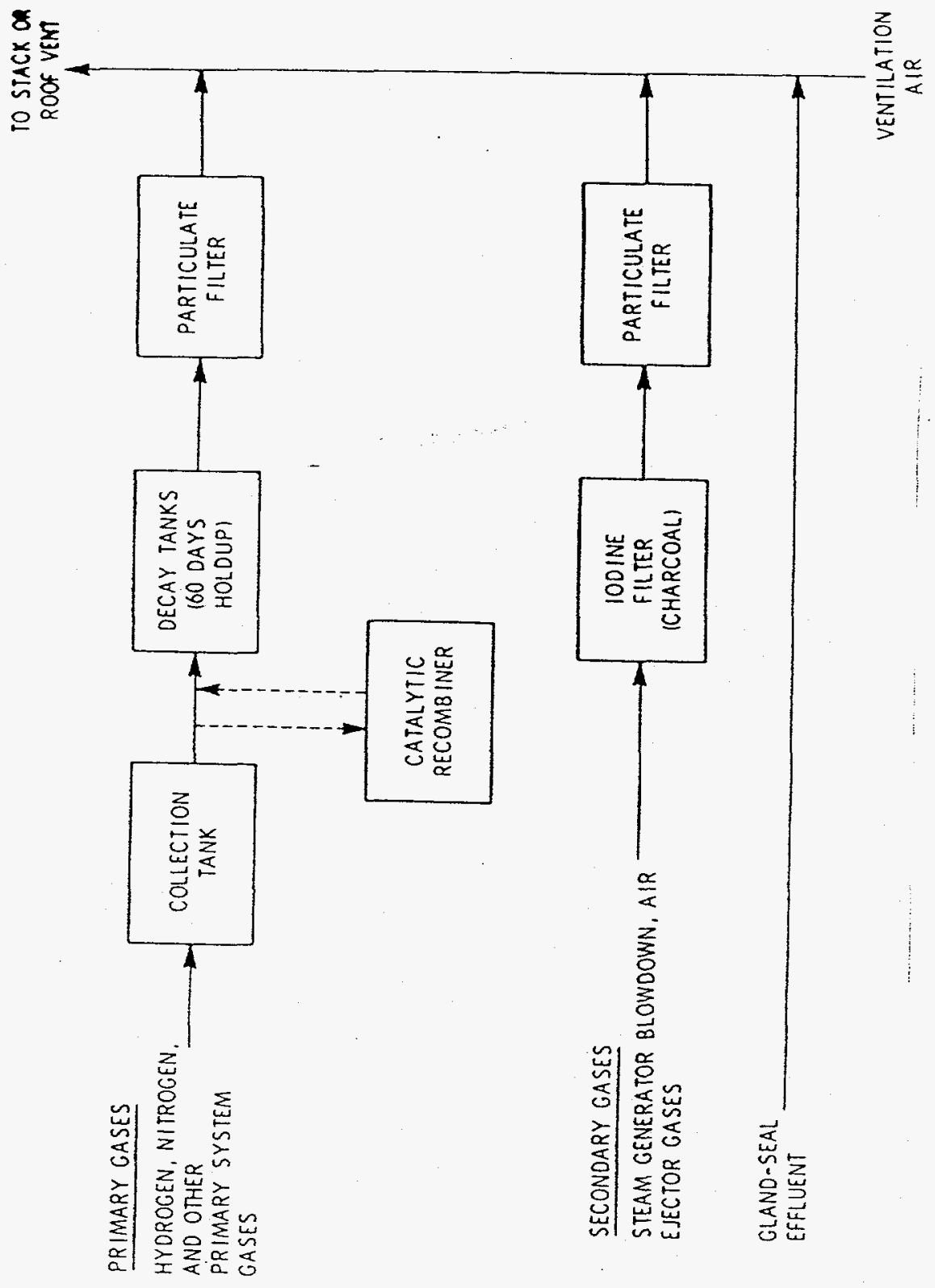

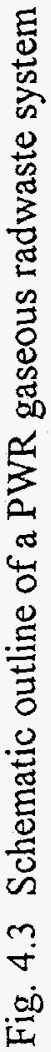


( 


\subsection{RESOURCE NEEDS}

\subsection{Materials/Resources Consumed During Operation}

Materials/resources requirements for operation of the plutonium disposition ALWR should not differ from requirements for an equivalent uranium-fueled facility. Consequently, data developed for the ALWR Tritium Supply Plant (Ref. 1) have been assumed applicable for the plutonium disposition ALWR as well.

\subsubsection{Utilities}

Table 5-1 summarizes utilities consumed annually during operation for a single large ALWR and single small ALWR located on a generic "dry" site. Table 5-2 provides equivalent information for the same reactors located on a generic "wet" site. On the dry site, heat is ultimately dissipated to the atmosphere through nonevaporative-type cooling towers. Cooling water from the cooling towers circulates through heat exchangers in the various plant systems ${ }^{1}$, and heated water returns to the cooling towers. The cooling towers reject heat to the atmosphere, cooling the water for recirculation to the plant systems using the cooling water. During this process, there are normally no water losses (hence the term "dry"); the cooling water flows through closed passages in aircooled heat exchangers contained in the cooling towers.

On a "wet" site, a neighboring body of water (e.g., a river) supplies raw water to, and accepts treated discharge from, the site. Heat is ultimately dissipated to the atmosphere through evaporative-type cooling towers. In this case, water is lost into the atmosphere by evaporation and "drift" (coolant water droplets entrained in the air). A small portion of the circulating water (referred to as "blowdown") is also continually discharged to prevent buildup of dissolved solids in the cooling water. Unlike the "dry" site, which operates as a closed system, makeup water must be continuously added to compensate for losses due to drift, evaporation, and blowdown.

Table 5-1. Utilities Consumed During Operation - Dry Site

\begin{tabular}{|l|c|c|}
\hline \multirow{2}{*}{\begin{tabular}{c|c|} 
Utilities \\
\cline { 2 - 3 }
\end{tabular}} & \multicolumn{2}{|c|}{ Annual Average Consumption } \\
\cline { 2 - 3 } Electricity & $1,100,000 \mathrm{MWh}$ & Small ALWR \\
\hline Liquid Fuel & $200,000 \mathrm{gal}$ & $580,000 \mathrm{MWh}$ \\
\hline Natural Gas & $0 \mathrm{scf}$ & $110,000 \mathrm{gal}$ \\
\hline Raw Water & $90,000,000 \mathrm{gal}$ & $0 \mathrm{scf}$ \\
\hline
\end{tabular}

${ }^{1}$ Data extracted from the ALWR Tritium Supply Plant PEIS data report (Ref. 1), which in turn was based largely on information developed in SNL-1994 (Ref. 2).

\footnotetext{
${ }^{1}$ The major cooling water user is the main condensor for steam passing through the plant turbine. Other cooling water systems include component cooling water, chilled water systems for HVAC, and systems to remove residual heat from spent fuel storage systems and from the reactor during shutdown.
} 
Table 5-2. Utilities Consumed During Operation - Wet Site

\begin{tabular}{|l|c|c|}
\hline \multirow{2}{*}{\multicolumn{1}{c|}{ Utilities }} & \multicolumn{2}{c|}{ Annual Average Consumption } \\
\cline { 2 - 3 } & Large ALWR & Small ALWR \\
\hline Electricity $^{2}$ & $700,000 \mathrm{MWh}$ & $380,000 \mathrm{MWh}$ \\
\hline Liquid Fuel & $200,000 \mathrm{gal}$ & $110,000 \mathrm{gal}$ \\
\hline Natural Gas & $0 \mathrm{scf}$ & $0 \mathrm{scf}$ \\
\hline Raw Water & & \\
\hline
\end{tabular}

'Data extracted from the ALWR Tritium Supply Plant PEIS data report (Ref. 1), which in turn was based largely on information developed in SNL-1 994 (Ref. 2).

${ }^{2}$ Electricity and raw water consumption for the wet site are different from data for the dry site.

\subsubsection{Water Balance}

Figures 5-1 and 5-2, respectively, diagram annual water balances for a single large ALWR and single small ALWR located on a generic dry site. Figures 5-3 and 5-4, respectively, show the equivalent information for large and small reactors located on a generic wet site. As with the numerical data, this information is taken directly from Ref. 1. 


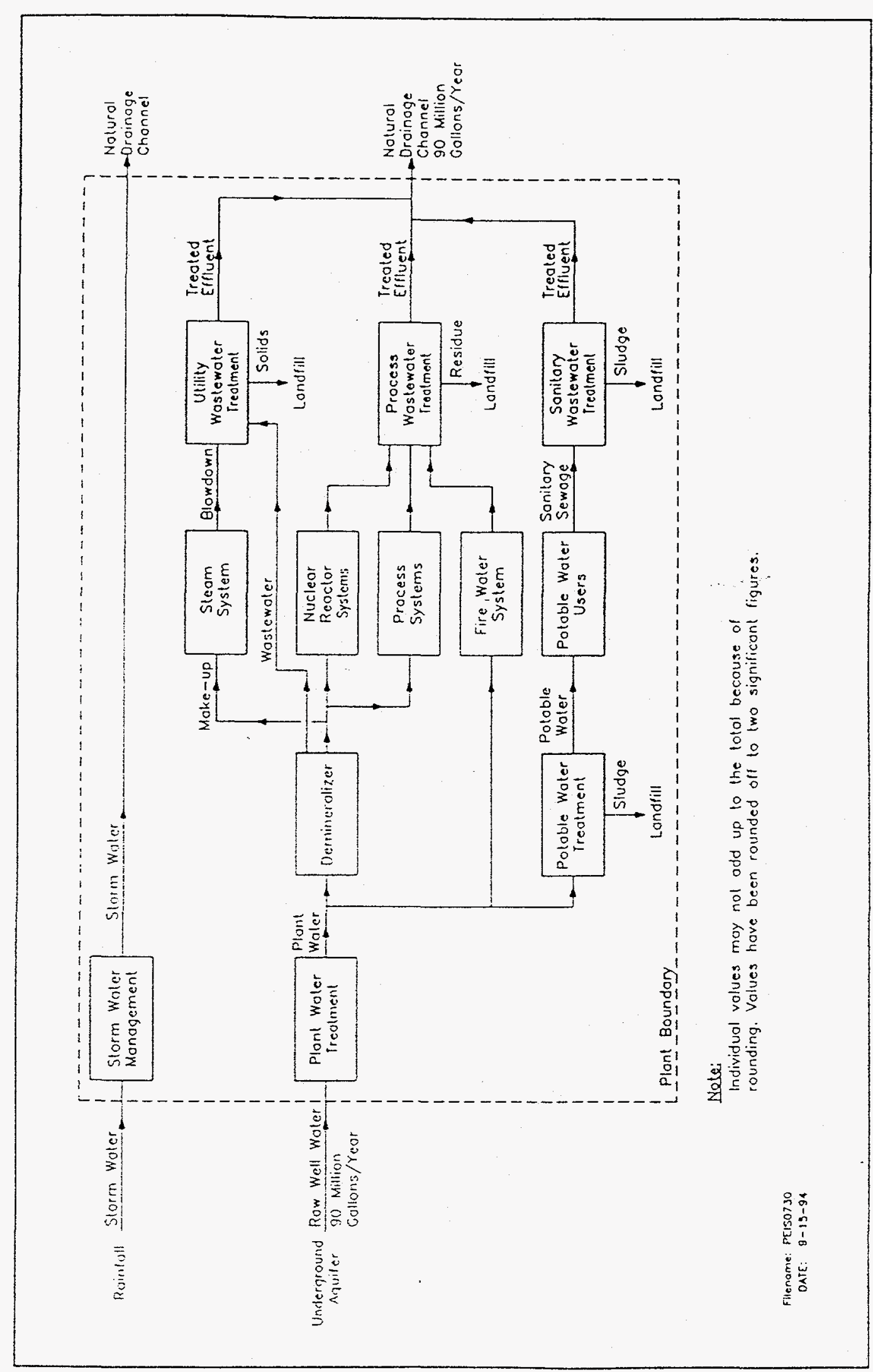

ALWR PEIS Data, Rev. 0 


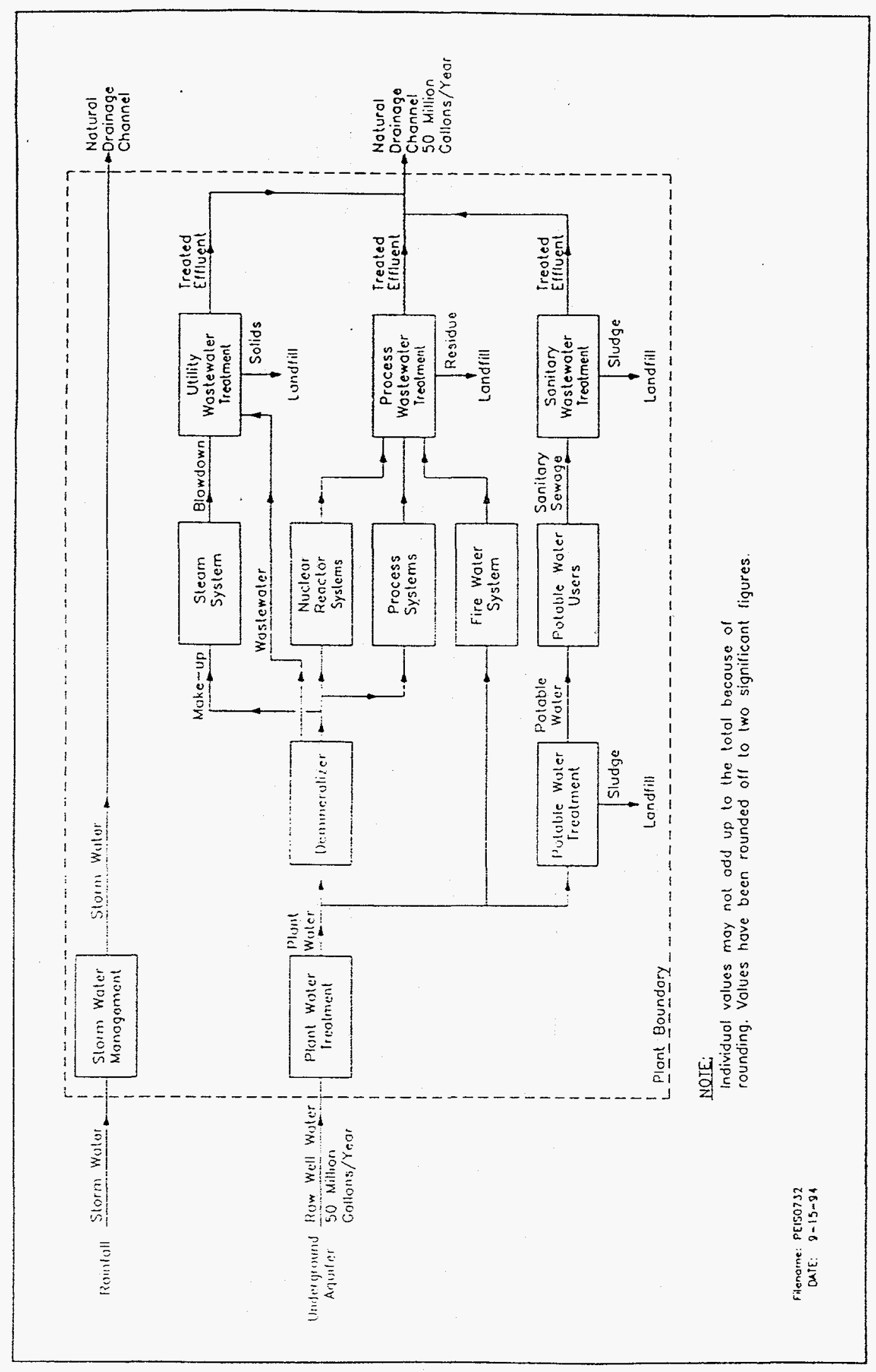




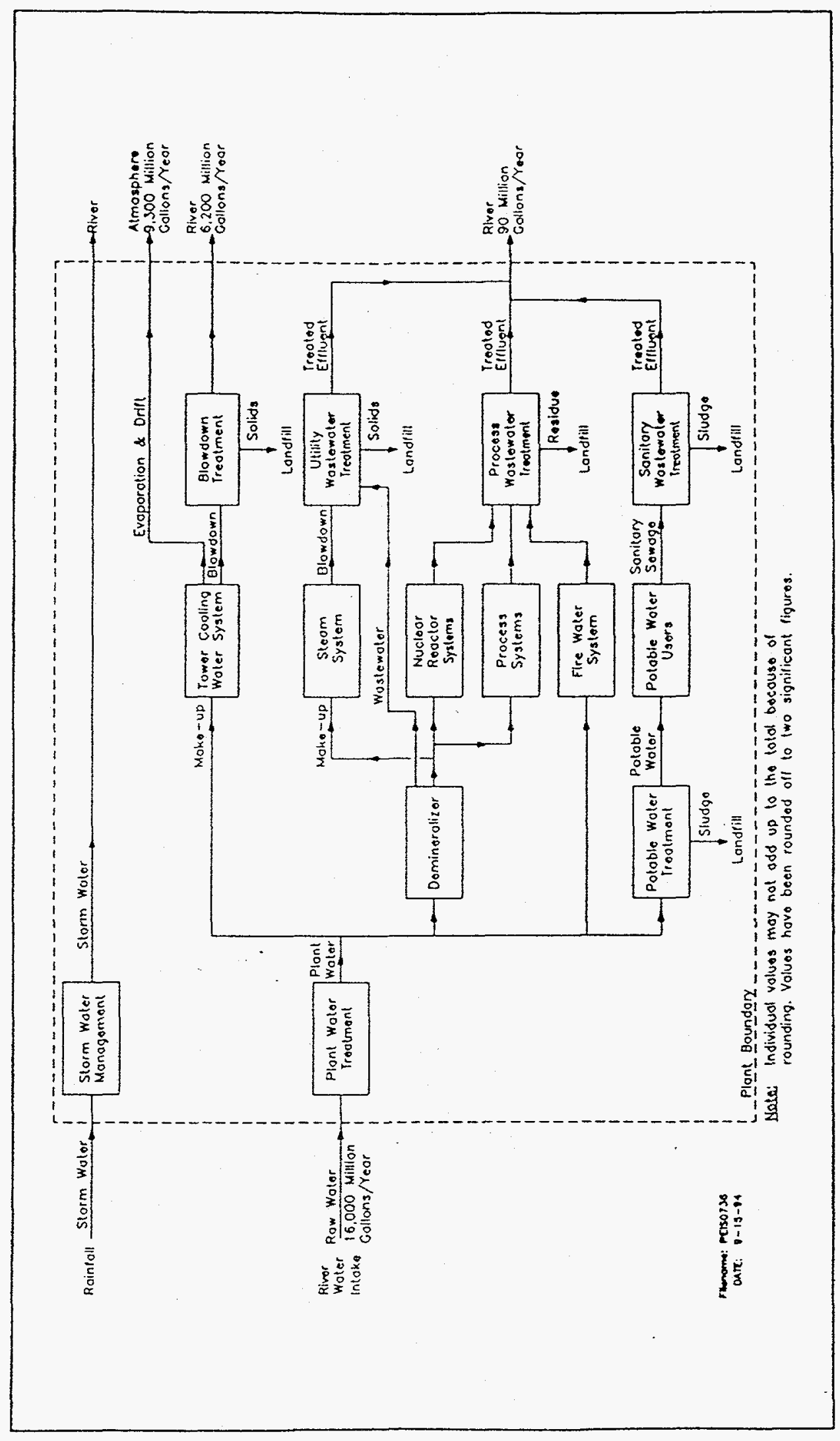

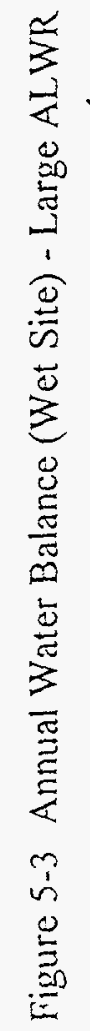




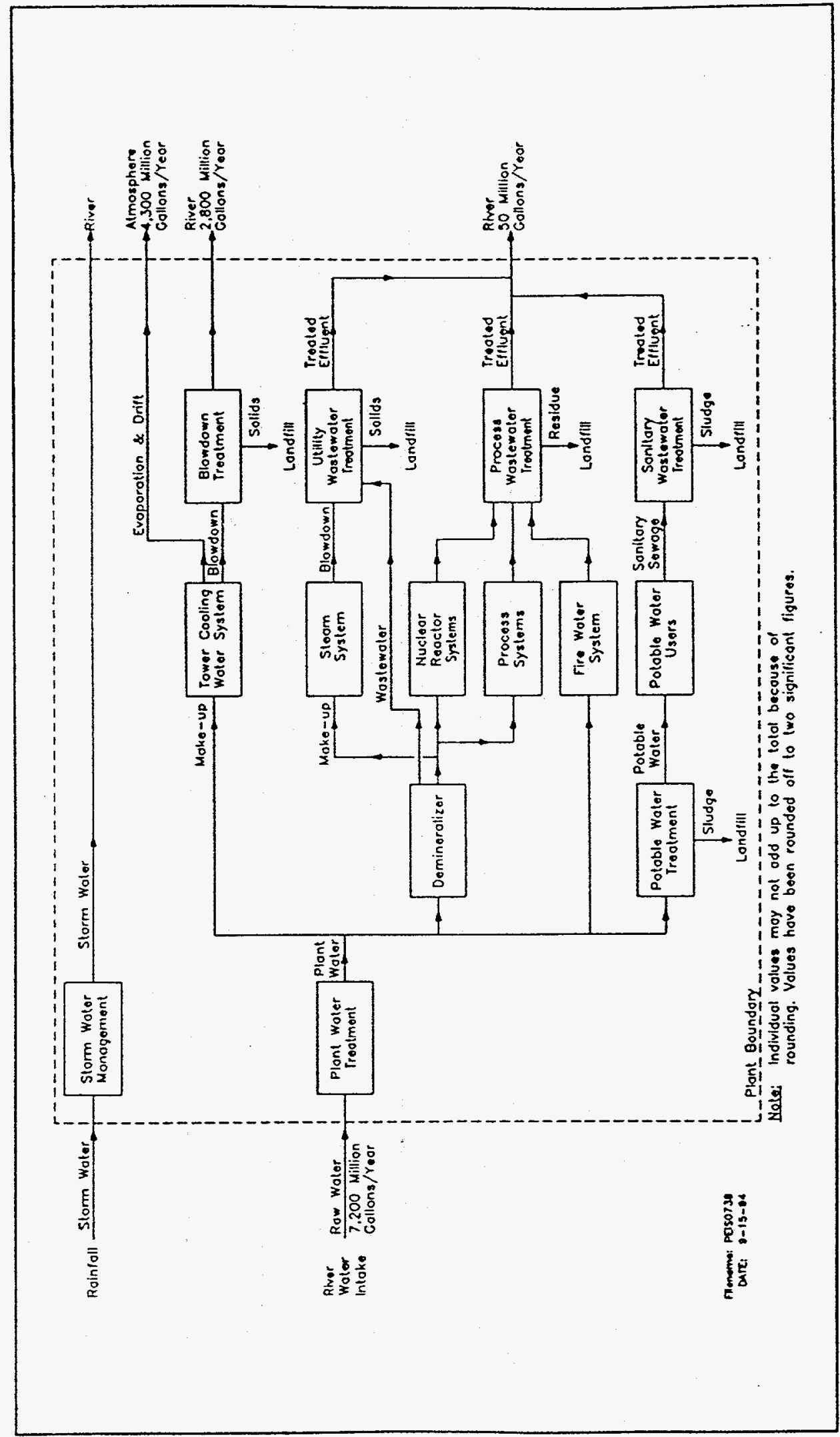

 


\subsubsection{Chemicals}

Table 5-3 summarizes chemicals consumed annually during operation of a single large and a single small ALWR reactor.

Table 5-3. Annual Chemicals Consumed During Operation

\begin{tabular}{|c|c|c|}
\hline \multirow{2}{*}{ Chemical } & \multicolumn{2}{|c|}{ Quantity (Ibm) } \\
\hline & Large ALWR & Small ALWR \\
\hline \multicolumn{3}{|l|}{ Solids } \\
\hline Aluminum Oxide ${ }^{2}$ & 3,500 & 1,900 \\
\hline Lithium Carbonate $^{2}$ & 2,600 & 1,400 \\
\hline Stainless Steel $\left.\right|^{2,3}$ & 17,000 & 9,300 \\
\hline Inconel $\left.\right|^{2,3}$ & 2,900 & 1,600 \\
\hline Zircaloy ${ }^{2,3}$ & 46,000 & 25,000 \\
\hline \multicolumn{3}{|l|}{ Liquids } \\
\hline Nitric Acid & $2,100,000$ & $1,200,000$ \\
\hline Water Treatment Chemicals ${ }^{4}$ & $2,000,000$ & $1,100,000$ \\
\hline \multicolumn{3}{|l|}{ Gases } \\
\hline Ammonia & 50,000 & 27,000 \\
\hline Argon & 72,000 & 39,000 \\
\hline Hydrogen & 2,400 & 1,300 \\
\hline Nitrogen & 730,000 & 400,000 \\
\hline
\end{tabular}

${ }^{1}$ Data extracted from the ALWR Tritium Supply Plant PEIS data report (Ref. 1), which in turn was based largely on information developed in SNL-1994 (Ref. 2).

${ }^{2}$ Based on data from DOE/NP-0014 (Ref. 3)

${ }^{3}$ Materials "consumed" by replacement of spent fuel assemblies with fresh fuel assemblies.

${ }^{4}$ Includes aluminum sulfate, bentonite, chlorine, diethylaminoethanol, hydrazine, inorganic phosphate, phosphoric acid, polyelelectrolyte, polyphosphate, sodium sulfite, and sulfuric acid. May be solid, liquid, or gas. 


\subsubsection{Radiological Materials Required}

Fuel assemblies using uranium and plutonium will be fabricated away from the reactor facility (although the fuel fabrication facility and reactor facility may eventually be co-located) and will then be shipped (or transported intra-site in the case of co-location) to the reactor facility.

\subsubsection{Beneficial Impacts}

In 1974, the U.S. Atomic Energy Commission (AEC) performed a study of the $\mathrm{UO}_{2}$ fuel cycle to assess all environmental effects related to $\mathrm{UO}_{2}$-fueled light water reactors (Ref. 4). This study concluded that essentially all of the environmental impact in the uranium fuel cycle for LWRs results not from the plants themselves, but rather from the mining, milling, conversion $\left(\mathrm{UF}_{6}\right)$, and enrichment phases of the cycle.

The mixed-oxide fuel to be utilized in the plutonium disposition ALWR will be fabricated from plutonium for which the dominant environmental effects have already occurred (i.e., during weapons production). Consequently, substantial environmental impacts associated with producing an equivalent amount of electricity from $\mathrm{UO}_{2}$-fueled reactors will be avoided, resulting in a net positive environmental impact. Section 7.3 summarizes avoided environmental impacts for the reference case large and small ALWR disposition facility and compares these with the equivalent results of the AEC study.

As quantified in Table 7-5, the beneficial environmental impact arises partly from avoided consumption of materials and resources in the uranium mining, milling, conversion, and enrichment process. For example, consumption of fossil fuels to meet the very large electric power demands for uranium enrichment are avoided altogether. 


\subsection{Material/Resources Consumed During Construction}

Materials/resources requirements for construction of the plutonium disposition ALWR should not differ from requirements for construction of an equivalent uranium-fueled facility. Consequently, data developed for the ALWR Tritium Supply Plant have been assumed applicable for the plutonium disposition ALWR as well.

\section{Table 5-4 Materials/Resources Consumed During Construction'}

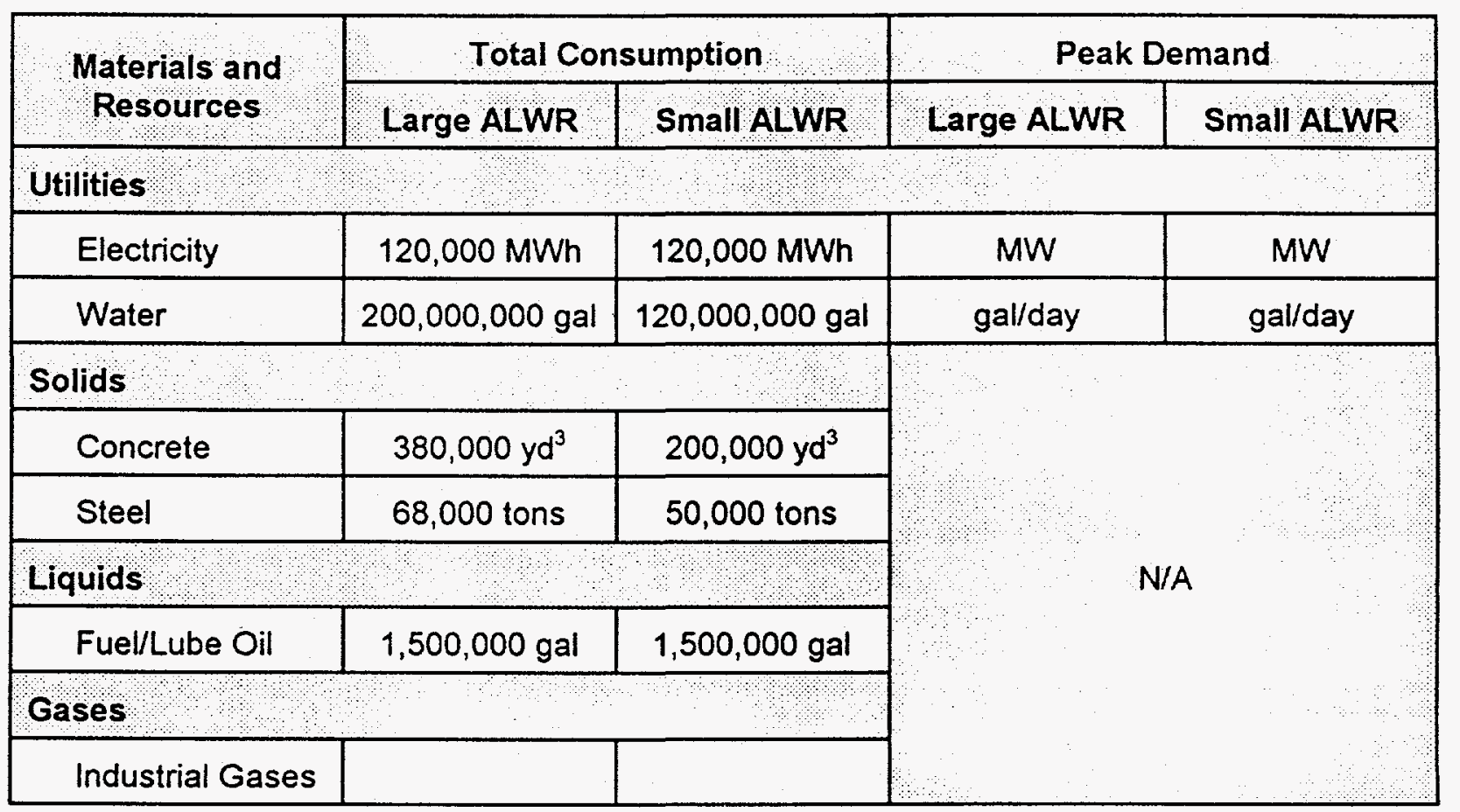

${ }^{1}$ Data extracted from the ALWR Tritium Supply Plant PEIS data report (Ref. 1), which in turn was based largely on information developed in SNL-1994 (Ref. 2). 


\section{References}

1. Data Report on Advanced Light Water Reactor Tritium Supply Plant, Advanced Technology Business Unit, Fluor Daniel, Inc., DOE Contract DE-AC05-91OR21964 (September 1994)

2. Data for Preparing a Programmatic Environmental Impact Statement (PEIS) for a Tritium Production Advanced Light Water Reactor (ALWR), Sandia National Laboratories, Report SNL-1994 (January 1994)

3. Environmental and Other Evaluations of Alternatives for Siting, Constructing and Operating New Production Reactor Capacity, U.S. Department of Energy, Report DOE/NP-0014 (September 1992)

4. Environmental Survey of the Uranium Fuel Cycle, U.S. Atomic Energy Commission, Report WASH-1248 (April 1974) 


\subsection{EMPLOYMENT NEEDS}

\subsection{Employment Needs During Operation}

Table 6-1 shows employment estimates in each labor category required for operation of the large and small plutonium disposition ALWR. The data in Table 6-1 includes employees from the Maintenance and Operation contractor, support organizations, and DOE.

Table 6-1. Employment Needs During Operation

\begin{tabular}{|l|c|c|}
\hline \multirow{2}{*}{ Labor Category } & \multicolumn{2}{|c|}{ Number of Employees } \\
\cline { 2 - 3 } & Large ALWR & Small ALWR \\
\hline Officials and Managers & 130 & 70 \\
\hline Professionals & 300 & 180 \\
\hline Technicians & 200 & 120 \\
\hline Office and Clerical & 20 & 10 \\
\hline Craft Workers & 40 & 30 \\
\hline Operatives & 80 & 50 \\
\hline Laborers & 10 & 10 \\
\hline Service Workers & 50 & 30 \\
\hline TOTALEMPLOYEES & 830 & 500 \\
\hline
\end{tabular}

The labor categories used in Table 6-1 are defined below. These categories are standard Equal Employment Opportunity (EEO) categories. The definitions were adapted in the ALWR Tritium Supply Plant PEIS from those used at the Y-12 plant in Oak Ridge, Tennessee, and are used verbatim for the plutonium disposition ALWR.

\section{Officials and Managers}

Occupations requiring administrative and managerial personnel who set broad policies, exercise overall responsibility for execution of these policies, and direct individual departments or special phases of a firm's operations. Included in this category are: officials, executives, middle management, plant managers, department managers and superintendents, salaried supervisors who are members of management, and purchasing agents and buyers.

'The material in this section has been extracted from the ALWR Tritium Supply Plant PEIS data report (Ref. 1), which in turn was based largely on information developed in SNL-1994 (Ref. 2). 


\section{Professionals}

Occupations requiring either a college degree or experience of such kind and amount as to provide a comparable background degree. Included in this category are: accountants and auditors, architects, artists, chemists, designers, editors, engineers, lawyers, librarians, mathematicians, natural scientists, registered professional nurses, personnel and labor relation specialists, physical scientists, physicians, social scientists, and teachers.

\section{Technicians}

Occupations requiring a combination of basic scientific knowledge and manual skill which can be obtained through two years of post high school educations, such as is offered in many technical institutes and junior colleges, or through equivalent on-the-job training. Included in these occupations are: computer programmers, drafters, engineering aides, junior engineers, mathematical aides, licensed, practical or vocational nurses, photographers, radio operators, scientific assistants, surveyors, technical illustrators, and technicians (medical, dental, electronic, physical science).

\section{Office and Clerical}

This category includes all clerical-type work, regardless of level of difficulty, where the activities are predominantly nonmanual, though some manual work not directly involved with altering or transporting the products in included. Included in this category are: bookkeepers, collectors (bills and accounts), messengers and office helpers, office machine operators (including computer), shipping and receiving clerks, stenographers, typists and secretaries, telephone operators, and legal assistants.

\section{Craft Workers (Skilled)}

Manual workers of relatively high skill level having a thorough and comprehensive knowledge of the processes involved in their work. Exercise considerable independent judgement and usually receive an extensive period of training. Included in this category are: the building trades, hourly-paid supervisors and lead operators who are not members of management, mechanics and repairers, skilled machining occupations, compositors and typesetters, electricians, engravers, painters (construction and maintenance), and pattern and model makers.

\section{Operatives (semiskilled)}

Workers who operate machine or processing equipment or perform other factory-type duties of intermediate skill level which can be mastered in a few weeks and require only limited training. Included in this category are: apprentices (auto mechanics, plumbers, bricklayers, carpenters, electricians, machinists, mechanics, building trades, metalworking trades, printing trades, etc.), operatives, attendants (auto service and parking), blasters, delivery workers, furnace workers, laundry operatives, milliners, motor operators, oilers and greasers (except auto), painters (manufactured articles), photographic process workers, stationary fire fighters, truck drivers, welders, flamecutters, electrical and electronic equipment assemblers, inspectors, testers and graders, and handpackers and packagers. 


\section{Laborers (unskilled)}

Workers in manual occupations which generally require no special training who perform elementary duties that may be learned in a few days that require the application of little or no independent judgement. Included in this category are: garage laborers, car washers, greasers, groundskeepers and gardeners, stevedores, laborers performing lifting, digging, mixing, and loading and pulling operations.

\section{Service Workers}

Workers in both protective and nonprotective service occupations. Included in this category are: attendants (hospital and other institutions, professional and personal service, including nurses aides, and orderlies), cooks, counter and fountain workers, elevator operators, fire fighters and fire protection, guards, doorkeepers, stewards, janitors, police officers and detectives, recreation facilities attendants, guides, and public transportation attendants.

\subsection{Employees at Risk of Radiological Exposure}

Based on the number of employees expected to be routinely involved in operations, approximately 210 badged employees for the large ALWR and 125 badged employees for the small ALWR could be at risk for occupational radiation exposure (ORE). Total annual workers dose from routine radiological exposure is approximately 170 person-rem for the large ALWR and 100 person-rem for the small ALWR based on data from SNL-1994. These values fall between the average and lower-bound worker exposure levels (about 300 and 100 person-rem, respectively) estimated by ORNL for all operations connected with plutonium disposition in existing (large) LWR facility (Ref. 3); as for the existing LWR, MOX operations are expected to increase ORE only negligibly over that for a uranium reactor, less than one percent. This result is consistent with the expectation that ALWR ORE would be lower than that for an LWR of equivalent power rating.

\subsection{Employment Needs During Construction}

Estimated employment needs during construction are presented in Table 6-2.

Table 6-2. Reactor Construction Employees Needed by Year

\begin{tabular}{|c|c|c|}
\hline Year & Large ALWR & Small ALWR \\
\hline 1 & 300 & 180 \\
\hline 2 & 3000 & 1000 \\
\hline 3 & 3500 & 2200 \\
\hline 4 & 3500 & 2200 \\
\hline 5 & 2000 & 1060 \\
\hline 6 & 300 & 460 \\
\hline
\end{tabular}




\section{References}

1. Data Report on Advanced Light Water Reactor Tritium Supply Plant, Advanced Technology Business Unit, Fluor Daniel, Inc., DOE Contract DE-AC05-91OR21964 (September 1994)

2. Data for Preparing a Programmatic Environmental Impact Statement (PEIS) for a Tritium Production Advanced Light Water Reactor (ALWR), Sandia National Laboratories, Report SNL-1994 (January 1994)

3. FMDP LWR PEIS Data Report, Fissile Materials Disposition Program, Oak Ridge National Laboratory, Report ORNL/MD/LTR-9, Rev. 2 (February 1995) 


\subsection{WASTE AND EMISSIONS}

Waste and emissions generated and discharged from the plutonium disposition ALWR should in most regards be similar to those generated from the uranium-fueled ALWR. The differences in the fission fragments as a result of more Pu-239 fissions in the plutonium disposition ALWR than that in a uranium-fueled ALWR should present only minor differences in radioactivity of the primary coolant inventory. For PEIS purposes, the amount of radioactive waste and effluent emitted from a uranium-fueled ALWR are assumed to represent those of an equivalent-size plutonium disposition ALWR. The non-radioactive and hazardous wastes generated during plant construction and operation should be identical for the two fuel-type ALWRs.

Upon the selection of a specific type of plutonium disposition ALWR, the waste and emissions generated during plant construction and operation should be calculated based on plant specific data.

\subsection{Waste and Emissions During Operation}

For a plutonium disposition ALWR, non-radioactive air pollutants would be generated as a result of surveillance testing of emergency diesel equipment. Chemical used in plant operation for the purpose of preventing corrosion and maintaining liquid $\mathrm{pH}$ level would also be discharged into the liquid effluent stream. For radioactive wastes, facilities for the treatment of gaseous, liquid and solid radioactive wastes are provided to treat (1) the gaseous and liquid effluent before they are release to the environment, and (2) the solid waste to reduce volume before they are sent to final disposal.

\subsubsection{Emissions (Gaseous and Liquid)}

\subsubsection{Emissions of Air Pollutants}

For emergency response purposes, an ALWR would be equipped with at least two standby diesel generators. Periodic startup tests are performed once per week for an hour for each diesel engine. The total air pollutants from testing of these diesel engines during station operation is estimated (Ref. 1) and shown in Table 7-1.

\subsubsection{Liquid Emissions of Chemical Pollutants}

Operation of the in-plant treatment systems would result in chemical pollutants discharged into the liquid effluent waste stream. These chemicals would be diluted by mixing a small waste discharge stream with a large amount of circulating cooling water before discharged into the environment. These waste effluents are monitored at the discharge outlets to ensure that the levels of concentration meet federal and state/local release limits.

Usages of some of these chemicals during plant operation are described below:

- Trisodium and disodium phosphate are used to control steam generator $\mathrm{pH}$.

- Hydrazine is used in the secondary system to control oxygen in steam generators.

- Lithium hydroxide is used in the primary system for $\mathrm{pH}$ control.

- Boric acid is used in primary system as a chemical shim for reactivity control.

- Potassium chromate is used as corrosion inhibitor in closed cooling water system.

- Sodium hydroxide is used for regeneration of primary system demineralizers. 
- Detergent is used in the plant laundry.

Estimates of the annual quantities of some of these chemical pollutants for a typical large ALWR (Ref. 2) are shown in Table 7-1. For a small ALWR, it is assumed that the usages of these chemicals are proportional to the power rating of the plant, and hence, the annual emissions of these chemical pollutants would be reduced according to the ratio of the two power ratings.

\subsubsection{Gaseous and Liquid Radiological Emissions}

During normal plant operation, small amounts of radioactive fission products would be released to the environment via several gaseous and liquid discharge pathways. Assuming the plutonium disposition ALWR is a large advanced pressurized water reactor with recirculating U-tube steam generators, radioactive gaseous and liquid releases could be estimated based on the following operating and leakage assumptions (Ref. 3):

- equivalent fuel defect, $<1 \%$

- core thermal power, $\sim 3500 \mathrm{MWt}$

- plant capacity, $80 \%$

- leak rate from primary to secondary systems, $75 \mathrm{lbs} /$ day

- total steam flow rate, $1.5 \times 10^{7} \mathrm{lbs} / \mathrm{hr}$

- steam blowdown rate, $7.5 \times 10^{4} \mathrm{lbs} / \mathrm{hr}$

- mass of water in steam generators, $4.5 \times 10^{5} \mathrm{lbs}$

\subsection{Radioactive Gaseous Effluents}

The sources for gaseous effluents of radioactive materials (noble gases, radioactive particulates, and iodine) during operation of an ALWR are primarily from:

- Gaseous radwaste system

- Condenser air removal system (such as air ejector)

- Turbine steam seal system

- Containment purge exhaust

- Ventilation exhaust from the auxiliary, turbine, and radwaste building

Estimates of radioactive gaseous effluents released to the environment per year are included in Table 7-2. For the large ALWR, gaseous emissions estimated for the MOX-fueled existing LWR (Ref. 4) are assumed to bound emissions for the ALWR. Without any detailed design data on the small ALWR, it is assumed that the effluent released quantities would be adjusted from those of the large ALWR based on the ratio of the two thermal power ratings, in accordance with the guidelines of ANSI/ANS Standard 18.1 (Ref. 5).

\subsection{Radioactive Liquid Eflluents}

The average annual radioactive liquid releases from an ALWR are estimated based on the following operating conditions: 
- Direct discharge of all turbine building sumps.

- Discharge of steam generator blowdown liquid after treatment

- Discharge of low total dissolved solids (TDS) waste after filtration and ion exchange.

- Discharge of high TDS evaporator distillate after filtration and ion exchange.

- Discharge of boron recovery system evaporator distillate after demineralization.

- Discharge of condensate polishing demineralizer regenerant solution

Estimates of radioactive liquid effluents released per year are included in Table 7-2. As for the gaseous emissions, liquid emissions estimated for the MOX-fueled existing LWR (Ref. 4) are assumed to bound those for the ALWR. Liquid emissions for the small ALWR are adjusted from those of the large ALWR based on the ratio of the two thermal power ratings.

\subsubsection{Solid Wastes}

\subsubsection{Spent Nuclear Fuel}

Spent MOX fuel discharged from the plutonium disposition ALWR during plant operation would be considered as high-level wastes according to 10 CFR 60 criteria. Spent fuel volumes are based on information developed by the reactor vendors during the DOE Plutonium Disposition Study for an ABB-CE System 80+ pressurized water reactor (Ref. 6), representing the large ALWR, and for a Westinghouse PDR-600 pressurized water reactor (Ref. 7), representing the small ALWR. Table 7-3 summarizes the detailed development of spent fuel volumes for each size of reactor.

Following irradiation, spent MOX assemblies would be stored in a water-filled spent-fuel pool on the reactor site. Final disposition of the spent MOX fuel would depend on the availability of a geologic repository (see footnote, page 2-2) and the suitability of disposing the spent MOX fuel in such a repository. For the time being, the spent fuel is assumed to meet the "Spent Fuel Standard" defined by the National Academy of Science study on weapons plutonium disposition.

\subsubsection{Transuranic Wastes}

Transuranic (TRU) wastes are wastes contaminated with alpha-emitting radionuclides with half-lives greater than 20 years and concentrations greater than $100 \mathrm{nCi} / \mathrm{g}$. The plutonium disposition ALWR should not generate any TRU wastes during plant operation. Co-locating a MOX fuel processing and fabrication facility within the ALWR plant site would produce TRU wastes due to MOX fuel processing and fabrication. If TRU wastes are generated by the MOX fuel processing and fabrication facility, they would be stored on-site pending on the eventual disposal of in the Waste Isolation Pilot Plant (WIPP).

\subsubsection{Low-Level Wastes}

Operation of the ALWR results in the generation of low-level radioactive wastes. The wastes generated include process wet wastes (for an ALWR, these would be spent resins, concentrate liquid, filter sludge and filter cartridge, etc) and dry active wastes (DAW, such as protective clothing, replaced equipment, etc.). The annual low-level waste (LLW) generation rates for a large and small ALWR, with and without volume-reduction treatments are estimated (Ref. 6) 
and shown in Tables $7-4 a$ and $7-4 b$, respectively, for dry and wet facility sites. Note that the waste volumes generated annually with volume reduction would depend strongly on which technique is selected. The post-treated volumes in Tables $7-4 \mathrm{a}$ and $7-4 \mathrm{~b}$ assume an overall compaction factor of $3: 1$.

Low-level radioactive waste drums and containers are packaged and shipped to a regional Low-Level Radioactive Waste Compact for final shallow-land disposal.

\subsubsection{Mixed Transuranic Wastes}

Mixed TRU wastes are those that contain characteristics of both TRU and hazardous wastes. Operation of a plutonium disposition ALWR is not expected to generate any mixed TRU wastes. Potential generation of this type of waste exists if the MOX fuel processing and fabrication facility is co-located within the ALWR plant site. Examples of mixed TRU generated in a MOX fabrication facility are lead-lined neoprene gloves, TRU contaminated solvents, cleaning rugs and papers, etc. This type of wastes would be stored until suitable treatment and disposal methods are available. Generation of this waste should be minimized or eliminated by minimizing the use of hazardous chemical in processes involving TRU materials.

\subsubsection{Mixed Low-Level Wastes}

Mixed low-level wastes (LLWs) are those that contain characteristics of both LLWs and hazardous wastes. Operation of a plutonium disposition ALWR is not expected to generate any significant amount of mixed LLWs. Most of the chemicals selected for the use in LLW treatment process, such as spent resin, anticorrosion and anti-fouling solvents are non-hazardous, and they could be treated and disposed of as LLWs in shallow land burial compact. Every effort in plant operation would be made to segregate the radioactive waste from contaminating the potentially hazardous chemicals. Potential mixed LLWs would be treated on site for the possible segregation of LLWs from the hazardous chemicals. The disposal of the separated hazardous wastes should meet the land disposal criteria imposed by the Resource Conservation and Recovery Act (RCRA).

\subsubsection{Hazardous Wastes}

Nonradioactive hazardous wastes are those that contain characteristics identified by either or both of (1) RCRA, 40 CFR 261, as amended, or (2) the Toxic Substances Control Act (TSCA). These toxic corrosive, reactive, or ignitable substances are identified as posing health and environmental risks, and their uses on the ALWR site should be restricted. All RCRA-listed hazardous wastes generated on-site would either be rendered non-hazardous, or disposed of according to RCRA/TSCA criteria to meet the federal and state/local regulations.

\subsubsection{Nonhazardous (Sanitary) Wastes}

Solid sanitary wastes generated on-site in normal plant housekeeping activities do not posed a defined health risk (neither radioactive nor hazardous). Their disposal to municipal garbage dumps should meet the RCRA, Subtitle D requirement.

Liquid sanitary wastes include sewage and industrial waste, such as detergent used in the plant laundry. The liquid sanitary wastes are treated in a wastewater process before discharge to a publicly owned treatment plant or surface water. The discharge of liquid sanitary wastes should meet the Clean Water Act and the National Pollutant Discharge Elimination System (NPDES). 


\subsubsection{Nonhazardous (Other) Wastes}

Other nonhazardous wastes do not pose a defined health risk and could be disposed of at municipal or community garbage dumps.

Table 7-1. Annual Emissions During Operation'

\begin{tabular}{|c|c|c|}
\hline \multirow{2}{*}{$\begin{array}{c}\text { Pollutants } \\
\text { Criteria Pollutants }\end{array}$} & Annual Emissions (lbm) \\
\hline Sulphur Dioxide & 1000 & Small ALWR \\
\hline Nitrogen Dioxide & 5800 & 1000 \\
\hline Carbon Monoxide & $<100$ & 5800 \\
\hline Particulate Matter & negl. & $<100$ \\
\hline Lead & negl. & negl. \\
\hline Other Pollutants & & negl. \\
\hline Phosphate & 7000 & 3000 \\
\hline Hydrazine & 1500 & 700 \\
\hline Lithium hydroxide & 700 & 300 \\
\hline Boric acid & 85000 & 40000 \\
\hline Potassium chromate & 8500 & 4000 \\
\hline Sodium hydroxide & 3500 & 1600 \\
\hline
\end{tabular}

${ }^{1}$ Consolidated Edison Company, Environmental Report, Indian Point Nuclear Station Unit 3 (September 1972) 
Table 7-2. Annual Radiological Emissions During Operation

\begin{tabular}{|c|c|c|}
\hline \multirow{2}{*}{$\begin{array}{c}\text { Radiological } \\
\text { Isotope }\end{array}$} & \multicolumn{2}{|c|}{ Annual Release Rate (Ci/yr) } \\
\cline { 2 - 3 } & Large ALWR & Small ALWR \\
\hline Gaseous Effluents \\
\hline Ar-41 & $3.5 \times 10^{0}$ & $1.7 \times 10^{0}$ \\
\hline Kr-85 & $2.0 \times 10^{1}$ & $1.0 \times 10^{1}$ \\
\hline Kr-85m & $2.4 \times 10^{1}$ & $1.2 \times 10^{1}$ \\
\hline Xe-131m & $2.6 \times 10^{1}$ & $1.3 \times 10^{1}$ \\
\hline Xe-133 & $1.1 \times 10^{1}$ & $1.1 \times 10^{1}$ \\
\hline Xe-133m & $1.1 \times 10^{3}$ & $5.7 \times 10^{2}$ \\
\hline Xe-135 & $1.6 \times 10^{2}$ & $8.0 \times 10^{1}$ \\
\hline Tritium & $1.2 \times 10^{2}$ & $5.9 \times 10^{1}$ \\
\hline Liquid Effluents & & \\
\hline Fe-55 & $1.5 \times 10^{-1}$ & $7.4 \times 10^{-2}$ \\
\hline Co-58 & $1.7 \times 10^{-1}$ & $8.4 \times 10^{-2}$ \\
\hline Xe-133 & $3.9 \times 10^{\circ}$ & $1.9 \times 10^{0}$ \\
\hline Tritium & $7.0 \times 10^{2}$ & $3.5 \times 10^{2}$ \\
\hline
\end{tabular}

${ }^{1}$ MOX average from LWR PEIS Data Report (Ref. 4)

${ }^{2}$ Large ALWR value reduced by thermal power ratio 
Table 7-3. Spent Fuel Production for Reactor Disposition of Plutonium

\begin{tabular}{|c|c|c|}
\hline Fuel Characteristics at Discharge ${ }^{1}$ & Large ALWR ${ }^{2}$ & Small ALWR ${ }^{3}$ \\
\hline Number of fuel assemblies discharged (avg) & 241 & 48.3 \\
\hline Number of fuel rods per assembly & 228 & 264 \\
\hline Number of fuel rods discharged & 54948 & 12751 \\
\hline Pu mass discharged per cycle ( $\mathrm{kg} \mathrm{Pu})$ & 4859 & 1101 \\
\hline Pu-238 fraction $(\mathrm{kg} / \mathrm{kgPu})$ & 一 & - \\
\hline Pu-239 fraction $(\mathrm{kg} / \mathrm{kgPu})$ & 0.631 & 0.621 \\
\hline Pu-240 fraction $(\mathrm{kg} / \mathrm{kgPu})$ & 0.227 & 0.242 \\
\hline Pu-241 fraction $(\mathrm{kg} / \mathrm{kgPu})$ & 0.126 & 0.118 \\
\hline Pu-242 fraction $(\mathrm{kg} / \mathrm{kgPu})$ & 0.017 & 0.018 \\
\hline Fraction of Pu in heavy metal (kgPu/kgHM) & 0.0514 & 0.0510 \\
\hline Total mass heavy metal $(\mathrm{kg})$ & 94,533 & 21,588 \\
\hline Environment, Safety, and Health ${ }^{4}$ & Large ALWR & Small ALWR \\
\hline Spent fuel generated (fuel assemblies) & 1928 & 1692 \\
\hline Spent fuel generated $(\mathrm{kg})$ & $1,300,000$ & $1,200,000$ \\
\hline Spent fuel generated $\left(\mathrm{m}^{3}\right)$ & 337 & 338 \\
\hline
\end{tabular}

${ }^{1}$ Values given are per reactor

${ }^{2}$ ABB-CE System $80+$, single 48 -month cycle with three shuffles at nominally equal intervals

${ }^{3}$ Westinghouse PDR-600, three 20-month cycles

${ }^{4}$ Spent fuel generated during entire $\mathrm{Pu}$ disposition mission

${ }^{5}$ Two reactors over 25 -year mission duration

${ }^{6}$ Four reactors over 25-year mission duration 
Table 7-4a. Annual Waste Volumes During Operation - Dry Site ${ }^{1}$

\begin{tabular}{|c|c|c|c|c|}
\hline \multirow[b]{2}{*}{ Category } & \multicolumn{2}{|c|}{ Large ALWR } & \multicolumn{2}{|c|}{ Small ALWR } \\
\hline & $\begin{array}{c}\text { Generated } \\
\left(\mathrm{m}^{3}\right)\end{array}$ & $\begin{array}{c}\text { Post-Treated } \\
\left(\mathrm{m}^{3}\right)\end{array}$ & $\begin{array}{c}\text { Generated } \\
\left(\mathrm{m}^{3}\right)\end{array}$ & $\begin{array}{c}\text { Post-Treated } \\
\left(\mathrm{m}^{3}\right)\end{array}$ \\
\hline Spent Fuel ${ }^{2}$ & 7 & $\mathrm{~N} / \mathrm{A}$ & 3 & N/A \\
\hline High Level Waste (HLW) & None & None & None & None \\
\hline Transuranic (TRU) Waste & None & None & None & None \\
\hline Low-Level Waste (LLW) & 650 & 90 & 350 & 50 \\
\hline Mixed Transuranic Waste & None & None & None & None \\
\hline \multicolumn{5}{|l|}{ Mixed Low-Level Waste } \\
\hline Liquid & None & None & None & None \\
\hline Solid & 5 & 5 & 5 & 5 \\
\hline \multicolumn{5}{|l|}{ Hazardous Waste } \\
\hline Liquid & $\begin{array}{l}\text { Included in } \\
\text { solid }\end{array}$ & $\begin{array}{l}\text { Included in } \\
\text { solid }\end{array}$ & $\begin{array}{l}\text { Included in } \\
\text { solid }\end{array}$ & $\begin{array}{l}\text { Included in } \\
\text { solid }\end{array}$ \\
\hline Solid & 27 & 27 & 27 & 27 \\
\hline \multicolumn{5}{|c|}{ Nonhazardous (Sanitary) waste } \\
\hline Liquid & 342000 & 341000 & 190000 & 189000 \\
\hline Solid & 5280 & 1760 & 3210 & 1070 \\
\hline \multicolumn{5}{|c|}{ Nonhazardous (Other) waste } \\
\hline Liquid & $\begin{array}{c}\text { Included in } \\
\text { sanitary }\end{array}$ & $\begin{array}{l}\text { Included in } \\
\text { sanitary }\end{array}$ & $\begin{array}{l}\text { Included in } \\
\text { sanitary }\end{array}$ & $\begin{array}{l}\text { Included in } \\
\text { sanitary }\end{array}$ \\
\hline Solid $^{3}$ & 4430 & None & 2680 & None \\
\hline
\end{tabular}

${ }^{1}$ Volumes generated per reactor

${ }^{2}$ See Table 7-3 for detail. Total spent fuel generated per reactor uniformly averaged over 25-year disposition mission.

${ }^{3}$ Recyclable wastes 
Table 7-4b. Annual Waste Volumes During Operation - Wet Site ${ }^{1}$

\begin{tabular}{|c|c|c|c|c|}
\hline \multirow[b]{2}{*}{ Category } & \multicolumn{2}{|c|}{ Large ALWR } & \multicolumn{2}{|c|}{ Small ALWR } \\
\hline & $\begin{array}{c}\text { Generated } \\
\left(\mathrm{m}^{3}\right)\end{array}$ & $\begin{array}{l}\text { Post-Treated } \\
\left(\mathrm{m}^{3}\right)\end{array}$ & $\begin{array}{c}\text { Generated } \\
\left(\mathrm{m}^{3}\right)\end{array}$ & $\begin{array}{c}\text { Post-Treated } \\
\left(\mathrm{m}^{3}\right)\end{array}$ \\
\hline Spent Fuel ${ }^{2}$ & 7 & N/A & 3 & N/A \\
\hline High Level Waste (HLW) & None & None & None & None \\
\hline Transuranic (TRU) Waste & None & None & None & None \\
\hline Low-Level Waste (LLW) & 650 & 90 & 350 & 50 \\
\hline Mixed Transuranic Waste & None & None & None & None \\
\hline \multicolumn{5}{|l|}{ Mixed Low-Level Waste } \\
\hline Liquid & None & None & None & None \\
\hline Solid & 5 & 5 & 5 & 5 \\
\hline \multicolumn{5}{|l|}{ Hazardous Waste } \\
\hline Liquid & $\begin{array}{l}\text { Included in } \\
\text { solid }\end{array}$ & $\begin{array}{l}\text { Included in } \\
\text { solid }\end{array}$ & $\begin{array}{l}\text { Included in } \\
\text { solid }\end{array}$ & $\begin{array}{l}\text { Included in } \\
\text { solid }\end{array}$ \\
\hline Solid & 27 & 27 & 27 & 27 \\
\hline \multicolumn{5}{|c|}{ Nonhazardous (Sanitary) waste } \\
\hline Liquid & $2.39 \times 10^{7}$ & $2.38 \times 10^{7}$ & $1.10 \times 10^{7}$ & $1.1 \times 10^{7}$ \\
\hline Solid & 5280 & 1760 & 3210 & 1070 \\
\hline \multicolumn{5}{|l|}{ Nonhazardous (Other) waste } \\
\hline Liquid & $\begin{array}{l}\text { Included in } \\
\text { sanitary }\end{array}$ & $\begin{array}{l}\text { Included in } \\
\text { sanitary }\end{array}$ & $\begin{array}{l}\text { Included in } \\
\text { sanitary }\end{array}$ & $\begin{array}{l}\text { Included in } \\
\text { sanitary }\end{array}$ \\
\hline Solid $^{3}$ & 4430 & None & 2680 & None \\
\hline
\end{tabular}

${ }^{1}$ Volumes generated per reactor

${ }^{2}$ See Table 7-3 for detail. Total spent fuel generated per reactor uniformly averaged over 25 -year disposition mission.

${ }^{3}$ Recyclable wastes 


\subsection{Waste and Emissions Generated During Construction}

Construction impacts of the plutonium disposition ALWR will be equivalent to those for any reactor facility, independent of fuel type, of similar size. Consequently, data developed for the ALWR Tritium Supply Plant (Ref. 9) have been assumed applicable for the plutonium disposition ALWR as well. Where Tritium Supply Plant data were not available, it may be assumed that equivalent generic data for commercial LWR facilities will bound the plutonium disposition ALWR.

\subsubsection{Emissions}

Air pollutants are emitted during construction. The principal sources of such emissions are fuitive dust from land clearing, site preparation, excavation, and other construction activities, and exhaust from construction equipment, vehicles delivering construction materials, and vehicles carrying construction workers. Emissions during a peak construction year are shown in Table 7-6.

\subsubsection{Solid and Liquid Waste}

\subsubsection{Radioactive Waste}

No radioactive waste or mixed waste is generated during construction.

\subsubsection{Hazardous Waste}

Solid and liquid nonhazardous wastes generated during construction include concrete and steel construction waste materials, and sanitary wastewater. The steel construction waste is recycled as scrap material before completing construction. The remaining nonhazardous wastes generated during construction are disposed of through the construction project. Hazardous wastes generated during construction consist of such materials as waste adhesives, oils, cleaning fluids, solvents, and coatings. Hazardous wastes are packaged in DOT-approved containers and shipped offsite to RCRA-permitted treatment, storage, and disposal facilities.

\subsubsection{Nonhazardous Waste}

Non-hazardous solid and sanitary wastes are among conventional facility wastes that are nonregulated. Sanitary wastes will be disposed either in site septic systems, or will enter existing municipal systems for treatment and disposal. Other non-hazardous wastes include such items as garbage, trash, and items normally disposed at a community landfill. 
Table 7-5. Emissions During the Peak Construction Year

\begin{tabular}{|l|c|c|}
\hline \multirow{2}{*}{\multicolumn{1}{c|}{ Criteria Pollutants $^{*}$}} & \multicolumn{2}{c|}{ Annual Emissions (tons) } \\
\cline { 2 - 3 } & Large ALWR & Small ALWR \\
\hline Sulphur Dioxide $^{1}$ & 50 & 50 \\
\hline Nitrogen Dioxide $^{1}$ & 790 & 790 \\
\hline Volatile Organic Compounds $^{1}$ & 120 & 120 \\
\hline Carbon Monoxide $^{1}$ & 550 & 550 \\
\hline Particulate Matter PM-10 $^{1}$ & 1400 & 1400 \\
\hline
\end{tabular}

'Based on LWR peak construction year data from DOE/NP-0014 (Ref. 10)

Table 7-6. Average Annual Wastes During Construction'

\begin{tabular}{|l|c|c|}
\hline \multirow{2}{*}{ Waste Category } & \multicolumn{2}{|c|}{ Annual Quantity } \\
\hline Non-hazardous Liquid Waste (Sanitary) & Large ALWR & Small ALWR \\
\hline Non-hazardous Liquid Waste (Other) & $27,000,000 \mathrm{gal}$ & $15,000,000 \mathrm{gal}$ \\
\hline Non-hazardous Solid Waste & $500,000 \mathrm{gal}$ & $500,000 \mathrm{gal}$ \\
\hline Hazardous Waste & $15,000 \mathrm{yd}^{3}$ & $10,000 \mathrm{yd}^{3}$ \\
\hline
\end{tabular}

'from ALWR Tritium Supply Plant Data Report (Ref. 9) 


\subsection{Avoided Environmental Impacts}

In 1974, the U.S. Atomic Energy Commission (AEC) performed a study of the $\mathrm{UO}_{2}$ fuel cycle to assess all environmental effects related to $\mathrm{UO}_{2}$-fueled light water reactors (Ref. 11). This study concluded that essentially all of the environmental impact in the uranium fuel cycle for LWRs results not from the plants themselves, but rather from the mining, milling, conversion $\left(\mathrm{UF}_{6}\right)$, and enrichment phases of the cycle.

The mixed-oxide fuel to be utilized in the plutonium disposition ALWR will be fabricated from plutonium for which the dominant environmental effects have already occurred (i.e., during weapons production). Consequently, substantial environmental impacts associated with producing an equivalent amount of electricity from $\mathrm{UO}_{2}$-fueled reactors will be avoided, resulting in a net positive environmental impact. Table 7-7 summarizes avoided environmental impacts for the reference case large and small ALWR disposition facility and compares these with the equivalent results of the AEC study. 
Table 7-7 Annual Avoided Environmental Impacts

\begin{tabular}{|c|c|c|c|}
\hline Environmental Impact & Generic LWR' & Large ALWR ${ }^{2}$ & Small ALWR \\
\hline \multicolumn{4}{|l|}{ Land Use } \\
\hline Temporary use, $10^{4} \mathrm{~m}^{2}$ & 22.5 & 60.8 & 54.0 \\
\hline Permanent use, $10^{4} \mathrm{~m}^{2}$ & 1.71 & 4.6 & 4.1 \\
\hline Overburden moved, $10^{9} \mathrm{~kg}$ & 2.53 & 6.8 & 6.1 \\
\hline \multicolumn{4}{|l|}{ Water } \\
\hline Discharged, $\mathrm{m}^{3}$ & 40.13 & 108 & 96.3 \\
\hline \multicolumn{4}{|l|}{ Fossil Fuel } \\
\hline Coal, $10^{6} \mathrm{~kg}$ & 107.8 & 291 & 3946 \\
\hline Natural gas, $10^{6} \mathrm{~m}^{3}$ & 2.3 & 6.2 & 85.6 \\
\hline \multicolumn{4}{|c|}{ Chemical Effluents - Gaseous, $10^{6} \mathrm{~kg}$} \\
\hline $\mathrm{SO}_{x}$ & 4.1 & 11 & 9.8 \\
\hline $\mathrm{NO}_{\mathrm{x}}$ & 1.1 & 3 & 2.6 \\
\hline Hydrocarbon & 12.7 & 34 & 0.1 \\
\hline $\mathrm{CO}$ & 26.9 & 73 & 0.2 \\
\hline Particulates & 1.08 & 3 & 2.6 \\
\hline$F^{-}$ & 0.57 & 1.5 & 0 \\
\hline \multicolumn{4}{|c|}{ Chemical Effluents - Liquid, $10^{3} \mathrm{~kg}$} \\
\hline $\mathrm{SO}_{4}^{-}$ & 9.28 & 25 & 22.3 \\
\hline $\mathrm{NO}_{3}$ & 2.66 & 7.2 & 6.39 \\
\hline Fluoride & 8.22 & 22 & 19.7 \\
\hline $\mathrm{Ca}^{-}$ & 5.05 & 14 & 12.2 \\
\hline $\mathrm{Cl}^{+}$ & 7.88 & 21 & 18.9 \\
\hline $\mathrm{Na}$ & 10.9 & 29 & 26.1 \\
\hline $\mathrm{NH}_{3}$ & 1.4 & 3.8 & 3.36 \\
\hline Tailing solution & 225,000 & 607,000 & 540,000 \\
\hline $\mathrm{Fe}$ & 0.38 & 1 & 0.9 \\
\hline
\end{tabular}

(continued on next page) 
Table 7-7 (cont.) Annual Avoided Environmental Impacts

\begin{tabular}{|c|c|c|c|}
\hline Environmental Impact & Generic LWR' & Large ALWR ${ }^{2}$ & Small ALWR \\
\hline \multicolumn{4}{|l|}{ Effluents - Solids, $10^{3} \mathrm{~kg}$} \\
\hline Mill Tailings & 85,000 & 230,000 & 204,750 \\
\hline Enrichment Tails & 122 & 330 & 293 \\
\hline \multicolumn{4}{|l|}{ Radiological-Gas, Ci } \\
\hline $\mathrm{Rn}-222$ & 70 & 189 & 168 \\
\hline Ra-226 & 0.0188 & 0.05 & 0.045 \\
\hline Th-230 & 0.0188 & 0.05 & 0.045 \\
\hline Uranium (entrained) & 0.03 & 0.08 & 0.072 \\
\hline \multicolumn{4}{|l|}{ Radiological - Liquid, Ci } \\
\hline Uranium & 1.97 & 5.3 & 4.7 \\
\hline$R n-222$ & 0.003 & 0.008 & 0.008 \\
\hline Th-230 & 0.0014 & 0.004 & 0.003 \\
\hline \multicolumn{4}{|l|}{ Radiological - Solids, Ci } \\
\hline Other than high-level & 563 & 1520 & 1352 \\
\hline \multicolumn{4}{|l|}{ Thermal, $\mathrm{TJ}$} \\
\hline Process heat loads & 3263 & 8810 & 7830 \\
\hline
\end{tabular}

'Generic LWR (1000 Mwe) from Ref. 11

${ }^{2}$ Avoided impacts for two units (from Ref. 7)

${ }^{3}$ Avoided impacts for four units (from Ref. 7) 


\section{References}

1. Consolidated Edison Company, Environmental Report, Indian Point Nuclear Station Unit 3 (September 1972)

2. Taiwan Power Company, Preliminary Environmental Report, Section 5, for the 4th Nuclear Power Station, Units I and 2 (January 1986).

3. U.S. Nuclear Regulatory Commission, Calculation of Release of Radioactive Materials in Gaseous and Liquid Effluents from Pressurized Water Reactors (PWRs), Report NUREG-0017, Rev.1 (February 1985)

4. FMDP LWR PEIS Data Report, Fissile Materials Disposition Program, Oak Ridge National Laboratory, Report ORNL/MD/LTR-9, Rev. 2 (February 1995)

5. American Nuclear Society, ANSV/ANS Standard 18.1, "Radioactive Source Term for Normal Operation of Light Water Reactors" (last issued 1984, current draft October 1994)

6. DOE Plutonium Disposition Study - Screening Study for Evaluation of the Potential for the System 80+ to Consume Excess Plutonium, ABB Combustion Engineering, Inc., DOE Contract No. DE-AC03-93 SF19682 (April 1994)

7. PDR Plutonium Disposition Study Phase II Final Report, Westinghouse Electric Company, DOE Contract DE-AC03-93 SF19683 (April 1994)

8. Taiwan Power Company, Preliminary Environmental Report, Section 9, for the 4th Nuclear Power Station, Units I and 2 (January 1986)

9. Data Report on Advanced Light Water Reactor Tritium Supply Plant, Advanced Technology Business Unit, Fluor Daniel, Inc., DOE Contract DE-AC05-91OR21964 (September 1994)

10. Environmental and Other Evaluations of Alternatives for Siting, Constructing and Operating New Production Reactor Capacity, U.S. Department of Energy, Report DOE/NP-0014 (September 1992)

11. Environmental Survey of the Uranium Fuel Cycle, U.S. Atomic Energy Commission, Report WASH-1248 (April 1974) 
.

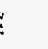

4 


\subsection{Design Process for Accident Mitigation ${ }^{1}$}

\subsection{Operational and Design Basis, and Beyond Design Basis Bounding Accidents}

The purpose of this section is to provide basic information that can be applied to the analysis of accident consequences for the large and small categories of advanced reactor designs. The large reactors considered here are the ABWR [GE 1994] and System 80+ [CE 1994] advanced reactor designs and the evolutionary APWR [WC 1994]. The small advanced reactor is the AP600 [WC 1994].

The safety design of the APWR, or PDR 1400 as designated for the Plutonium Disposition Study, is represented by the RESAR SP/90 Application and "no differences in PRA results are expected between the APWR and the PDR1400" [WC 1994 Section 10.2.2.2]. Nevertheless, the RESAR SP/90 Probabilistic Safety Study [WC 1985] is ten years old whereas many advances in plant safety design and emergency procedures have evolved during the last decade. For this reason, the accident source terms from WC 1985 are out of line with (higher than) the corresponding source terms for the ABWR or the System 80+ designs, both of which have recently (1994) been certified by the U.S. Nuclear Regulatory Commission (NRC).

Since the current purpose is to identify source terms and accident probabilities representative of the advances in reactor design that would be applied if the advanced reactor option for plutonium disposition were chosen, typical results will be taken from the recent safety studies for the ABWR and the System $80+$. Here it is recognized that the APWR design would be upgraded to current NRC standards if the PDR 1400 reactor were selected for plutonium disposition; its operation would require prior certification by the NRC.

Representative initial fission product inventories for the large advanced reactor are listed in Table 8-1. These are the 60 fission product isotope inventories that are normally represented in MACCS code [SNL 1990] calculations performed for the NRC. They are based on the use of low-enriched uranium $\left(\mathrm{UO}_{2}\right)$ fuel for the System $80+$ and $\mathrm{ABWR}$ designs and are the end-ofcycle inventories. The listed values are conservative in that the larger of the two inventories [System 80+ (TT 1994 Table 4.7) or ABWR (GE 1994 Table 2.3.2)] is taken for each isotope.

The cobalt isotopes ( $\mathrm{CO}-58$ and $\mathrm{CO}-60$ ) are not fission products, but rather activation products from the wear of valves (stellite) or stainless steel components. No values were provided by the respective vendors for these isotopes in either the System $80+$ or ABWR advanced reactor descriptions.

The representative initial fission product inventories for the small advanced reactor based upon the AP600, or PDR600 as designated for the Plutonium Disposition Study, are listed in Table 8-2. The listed values are taken from Table 1.3.4-3 of WC 1993. The reduced fission product inventories associated with the small reactor category are to some extent offset by the

\footnotetext{
'This analysis was prepared by ORNL and is documented in report ORNLMD/LTR-14, FMDP ALWR PEIS Data Report Attachment to Section 8 - Design Basis \& Severe Accident Source Term Analysis, Rev. 1 (March 29, 1995), from which this section was taken in full and verbatim.
} 
need to employ a larger number of the small reactors if plutonium disposition is to be accomplished at the same rate as for the large advanced reactors.

Differences in the nuclide inventories between a $\mathrm{MOX}$ core and a $\mathrm{UO}_{2}$ core for the advanced plants have been examined using information obtained from the vendors. The most complete listing of a MOX vs $\mathrm{UO}_{2}$ comparison is provided for the PDR600 [WC 1993]. This listing includes the standard 60 isotopic inventories (for a core using full $\mathrm{MOX}$ and for a core using $\mathrm{UO}_{2}$ ) for an advanced small (AP600) PWR having a thermal rating of $1993 \mathrm{MWth}$. The corresponding ratios of the $\mathrm{MOX}$ isotope inventories to the $\mathrm{UO}_{2}$ isotope inventories are listed in Table 8-3 under the "small" reactor heading.

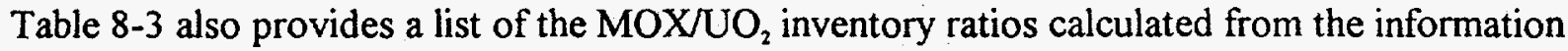
for the ABWR found in GE 1994. A comparison of these "large" reactor ratios with those for the small reveals that the largest differences are experienced for the heavy metal isotopes Am241, Pu-238, and Pu-241. No other isotopes have ratios that differ by a factor of two or more, and in most cases, the ratios differ only slightly. The larger differences for these three heavy metal isotopes are not important from the standpoint of fission product transport under accident conditions since heavy metals are not predicted to be released to the environment.

\subsubsection{Operational and Design Basis Accidents}

TT 1994 reports the results of studies conducted to assess the possible use of advanced lightwater reactors (ALWRs) for the purpose of tritium production. As part of that study, the Safety Analysis Reports (SARs) for the AP600, the System 80+, the ABWR, and the General Electric 600 MWe Simplified Boiling Water Reactor (SBWR) were examined to determine for each reactor which of the design basis accidents (DBAs) produced the highest dose. For all four advanced reactors, the loss-of-coolant accident (LOCA) with core melt was found to represent the worst case, on the basis of the two-hour exclusion boundary dose.

With the exception of the System $80+$, for which releases to the environment are not described in the SAR, the LOCA source terms associated with the respective advanced reactor designs are provided in Table 3-1 of TT 1994. The source terms listed in that Table for the AP600 (small advanced reactor) and the ABWR (large advanced reactor) design are also utilized here, as described in Sections 8.1.1.1 and 8.1.1.2 below.

\subsubsection{Bounding design-basis accident for the large advanced reactor}

The two-hour source term for the large advanced reactor design basis LOCA with core damage is listed in the right-hand column of Table 8-4. Since the ABWR was designed for use of generic fuel, much of the behavioral analyses for the ABWR, including the SSAR, is applicable to the ABWR with a MOX fueled core [GE 1994]

It should be noted that Table 8-4 indicates that the design basis accident releases to the environment would be confined to noble gases, iodine, and cesium. This is in line with NRC 1994, which explains the staff position:

“...for evaluation of design basis accidents (DBA) for the evolutionary and passive light-water reactor designs, only the releases associated with the gap and early invessel release phases will be used. ...ex-vessel and late in-vessel releases would 
only result from core damage accidents with vessel failure and core-concrete interactions. For evolutionary and passive light-water reactors, the estimated frequencies of such scenarios are low enough that they need not be considered..."

In other words, the reactor vessel is expected to remain intact so that only volatile fission product releases (noble gases, iodine, and cesium) need be considered.

Table 8-4 includes several fission product isotopes that are not among the 60 isotopes represented in the standard MACCS code input and for which the $\mathrm{MOX} / \mathrm{UO}_{2}$ core inventory ratios (Table 8-3) are not available. These non-standard isotopes include I-130, $\mathrm{Kr}-83 \mathrm{M}, \mathrm{Kr}-89$, $\mathrm{Xe}-131 \mathrm{M}, \mathrm{Xe}-133 \mathrm{M}, \mathrm{Xe}-137$, and Xe-138. Surrogate $\mathrm{MOX} / \mathrm{UO}_{2}$ ratios for these isotopes can be taken from the neighboring isotopes based upon similarity of atomic weight.

To obtain the initial core inventories for the $\mathrm{MOX}$-fueled reactors, the $\mathrm{UO}_{2}$-based initial core inventories (Tables $8-1$ or $8-2$ ) should be multiplied by the respective $\mathrm{MOX} / \mathrm{UO}_{2}$ fission product inventory ratios listed in Table 8-3. Correspondingly, the design basis two-hour releases listed in Table 8-4 should be adjusted by the same ratios. (Qualitatively, differences induced by utilization of $\mathrm{MOX}$ instead of $\mathrm{UO}_{2}$ fuel are minor in comparison with the uncertainties associated with basic accident source term calculations.)

\subsubsection{Bounding design-basis accident for the small advanced reactor}

The two-hour source term for the design basis LOCA with core damage is listed for the AP600 in the first column of Table 8-4. WC 1993 (Section 1.3.4.1) reports that the results of the Level 1 PRA performed on the AP600 plant provide a reasonable estimate of the postulated core damage frequency for the PDR600: "The initiating event and reliability data used for the AP600 PRA are applicable for the PDR600 since the systems and components are essentially the same for these two plants." Furthermore, "the results of the AP600 containment and fission product source term analysis can be assumed to provide a reasonable estimate of the fission product release to the environment for the PDR600."

The lower source term for the AP600 derives both from the smaller core (600 MWe vs $1400 \mathrm{MWe}$ for the ABWR) and from the passive protection features that are an integral part of the plant design. For plutonium disposition at the same rate, however, two small reactors would have to be assigned in place of one of the large reactors. Thus, for purposes of comparison, the source terms listed for the small reactor in Table 8-4 should be doubled if plutonium disposition at the same rate is a criterion.

\subsubsection{Beyond Design Basis Accidents}

This Section will present the release fractions associated with severe accidents for the advanced reactor designs. These release fractions are intended to be multiplied by the appropriate core fission product inventories [Tables 8-1 or 8-2] to obtain the source terms associated with $\mathrm{UO}_{2}$ fuel. The $\mathrm{MOX} / \mathrm{UO}_{2}$ inventory ratios provided in Table 8-3 can then be applied to calculate the source terms for the full MOX core. 


\subsubsection{Severe accident spectrum for the large advanced reactor}

Representative severe accident class frequencies and associated release fractions for the large advanced reactor are listed in Table $8-5$, in order of decreasing frequency. This information is derived from TT 1994, which provides the values drawn from the Safety Analysis Reports (SARs) filed with the U.S. Nuclear Regulatory Commission (NRC) for the ABWR and for the System 80+ reactor designs. [TT 1994 addresses the concept of advanced reactors modified for tritium production, but the release fractions listed therein for isotopes other than tritium are unchanged from the SAR values.] The release classes (1 through 8) are derived from information presented in the ABWR and System 80+ SARs and will be defined in the following paragraphs.

The ABWR release categories considered in TT 1994 are defined in the SAR depending upon containment conditions:

NCL Release associated with normal containment leakage.

Case 1 Release associated with opening of the containment rupture disk.

Case 7 Release associated with failure of the upper drywell pressure boundary (drywell head or penetrations) for cases with many hours between vessel failure and drywell failure.

Case 8 Release associated with early pressure-induced containment failure.

Case 9 Release associated with failure of the drywell head for an accident with delayed core damage and vessel failure.

A passive flooder is included in the ABWR containment design to maintain any core and structural debris on the drywell floor covered with water. The overlying water would serve to scrub gases rising from the debris of any accompanying fission products. There is an overlying pool of water for all cases listed above.

The severe accident class frequencies and associated release fractions considered in TT 1994 for the System $80+$ advanced reactor are defined in the SAR as classes 1.1E through 4.18L. Class $1.1 \mathrm{E}$, which represents an intact containment with successful operation of the annulus ventilation system corresponds to class NCL for the ABWR. That is, the releases are attributable to normal leakage, based on the design basis containment leakage of $0.5 \%$ per day [CE 1994a]. The E signifies that core damage occurs early for this class, within the first 8 hours.

The frequency per year associated with the class $1.1 \mathrm{E}$ source term is the sum of the frequencies for class $1.1 \mathrm{E}\left(1.36 \times 10^{-6}\right)$ and class $1.1 \mathrm{M}\left(3.83 \times 10^{-7}\right)$ as given in the SAR. Class $1.1 \mathrm{M}$ is 
identical to class $1.1 \mathrm{E}$ except that core damage occurs in the 8 to 24 hour time frame for class $1.1 \mathrm{M}$.

The TT 1994 report also provides the release fractions for class $2.2 \mathrm{E}$, which represents late containment failure with successful in-vessel fission product scrubbing with revaporization releases but without vaporization releases. The revaporization releases are successfully scrubbed. Vaporization releases occur for accident sequences in which a coolable debris bed is not established on the containment floor. Core-concrete interaction releases gases that sparge through the debris, carrying tellurium and low volatility isotopes into the containment atmosphere. Revaporization, on the other hand, pertains either to revolatilization of previously deposited fission products from reactor coolant system piping or structures as their temperatures increase or to radiolytic evolution of elemental iodine from the containment sump. Scrubbing of revaporization releases is accomplished by the operation of containment sprays.

The frequency per year $\left(1.1 \times 10^{-8}\right)$ associated with the $2.2 \mathrm{E}$ source term is the sum of the frequencies for classes $2.2 \mathrm{E}, 2.1 \mathrm{E}$, and $2.2 \mathrm{M}$. As before, E signifies core damage within the first 8 hours while $\mathrm{M}$ designates core damage in the 8 to 24 hour time frame. Release class $2.1 \mathrm{E}$ differs from class $2.2 \mathrm{E}$ in that neither vaporization nor revaporization releases occur in class 2.1E.

Class 2.6E considered in TT 1994 represents late containment failure with both vaporization releases and revaporization releases. Scrubbing is successful for all releases. Scrubbing of vaporization releases is accomplished either by the action of containment sprays, or by retention of fission products in water overlying the debris bed in the reactor cavity.

The frequency per year $\left(1.2 \times 10^{-7}\right)$ associated with the class $2.6 \mathrm{E}$ source term is the sum of the frequencies for classes $2.4 \mathrm{E}, 2.5 \mathrm{E}, 2.6 \mathrm{E}$, and $2.7 \mathrm{E}$. Class $2.7 \mathrm{E}$ differs from class $2.6 \mathrm{E}$ only in that scrubbing of the vaporization release is not successful. Classes $2.4 \mathrm{E}$ and $2.5 \mathrm{E}$ differ from class $2.6 \mathrm{E}$ in that they have no revaporization release.

Class 2.5M represents late containment failure with vaporization releases but no revaporization releases. In-vessel fission product scrubbing is successful, but scrubbing of the vaporization releases is not successful. Core damage occurs during the 8 to 24 hour time frame. The frequency per year associated with class $2.5 \mathrm{M}\left(2.6 \times 10^{-8}\right)$ is the sum of the frequencies for classes $2.5 \mathrm{M}, 2.6 \mathrm{M}, 2.7 \mathrm{M}$, and $4.8 \mathrm{E}$.

\begin{tabular}{l|cc|cc|c} 
Class & Vaporization & $\underline{\text { Scrubbed? }}$ & $\underline{\text { Revaporization }}$ & $\underline{\text { Scrubbed? }}$ & $\begin{array}{c}\text { In-vessel } \\
\text { scrubbed? }\end{array}$ \\
$2.5 \mathrm{M}$ & Yes & No & No & - & Yes \\
& Yes & Yes & Yes & Yes & Yes
\end{tabular}




\begin{tabular}{c|cc|cc|c} 
Class & Vaporization & $\underline{\text { Scrubbed? }}$ & $\underline{\text { Revaporization }}$ & $\underline{\text { Scrubbed? }}$ & $\begin{array}{c}\text { In-vessel } \\
\text { scrubbed? }\end{array}$ \\
$4.8 \mathrm{M}$ & Yes & No & Yes & Yes & Yes \\
Yes & Yes & Yes & No & Yes
\end{tabular}

Release class $4.8 \mathrm{E}$ differs from the other three represented by class $2.5 \mathrm{M}$ because it involves failure of containment isolation and core damage occurs within the first 8 hours.

Class 3.6E considered in TT 1994 represents early containment failure with both vaporization and revaporization releases and successful fission product scrubbing. The frequency per year $\left(1.8 \times 10^{-8}\right)$ conforms with $\mathrm{CE} 1994 \mathrm{a}$ and is the sum of the frequencies for classes $3.1 \mathrm{E}, 3.2 \mathrm{E}$, $3.4 \mathrm{E}$, and $3.6 \mathrm{E}$.

\begin{tabular}{l|cc|cc|c} 
Class & Vaporization & $\underline{\text { Scrubbed? }}$ & $\underline{\text { Revaporization }}$ & $\underline{\text { Scrubbed? }}$ & $\begin{array}{c}\text { In-vessel } \\
\text { 3crubbed? }\end{array}$ \\
$3.6 \mathrm{E}$ & Yes & Yes & Yes & Yes & Yes \\
$3.1 \mathrm{E}$ & No & - & No & - & Yes \\
$3.4 \mathrm{E}$ & No & - & Yes & Yes & Yes \\
& Yes & Yes & No & - & Yes
\end{tabular}

Finally, class 4.18L considered in TT 1994 involves a containment isolation failure with core damage occurring after 24 hours. In-vessel fission product scrubbing is successful, but the vaporization and revaporization releases are not successfully scrubbed. The frequency per year associated with class $4.18 \mathrm{~L}$ is the sum of the frequencies for $4.18 \mathrm{~L}\left(1.54 \times 10^{-8}\right), 4.12 \mathrm{E}$ $\left(3.30 \times 10^{-9}\right)$, and $4.4 \mathrm{E}\left(3.01 \times 10^{-9}\right)$. 


\begin{tabular}{l|cc|cc|c} 
Class & $\underline{\text { Vaporization }}$ & $\underline{\text { Scrubbed? }}$ & $\underline{\text { Revaporization }}$ & $\underline{\text { Scrubbed? }}$ & $\underline{\underline{\text { In-vessel }}}$ \\
4.18L & Yes & No & Yes & No & Yes \\
$4.12 \mathrm{E}$ & Yes & Yes & Yes & Yes & Yes \\
4.4E & Yes & No & No & - & Yes
\end{tabular}

Release classes $4.12 \mathrm{E}$ and $4.4 \mathrm{E}$ differ from release class $4.18 \mathrm{~L}$ in that the core damage occurs within the first 8 hours.

In summary, the release class column headings of Table 8-5 are defined as follows:

1. System $80+$ accident sequences involving normal containment leakage based on the source term for class 1.1E.

2. ABWR normal containment leakage accident sequences based on the source term. [Case $\mathrm{NCL}]$

3. System $80+$ late containment failure with both vaporization and revaporization releases, both scrubbed. [class $2.6 \mathrm{E}$ ]

4. System $80+$ late containment failure with vaporization releases, not scrubbed. (There are no revaporization releases). [class $2.5 \mathrm{M}$ ]

5. System $80+$ containment isolation failure with both vaporization and revaporization releases, no scrubbing of either release. [class 4.18L]

6. ABWR opening of the containment rupture disk on overpressure. [Case 1]

7. System $80+$ early containment failure with both vaporization and revaporization releases and scrubbing of both. [class 3.6E]

8. Late System $80+$ containment failure with revaporization releases (scrubbed) only. [class 2.2E]

All other severe accident containment release fractions for the large advanced reactors have values less than $1.0 \times 10^{-9}$. (This includes Cases 7,8 , and 9 for the ABWR, which are not represented in Table 8-5.) 


\subsubsection{Severe accident spectrum for the small advanced reactor}

The representative severe accident release classes and associated class frequencies for the small advanced reactor are listed in Table 8-6. This information is based upon the PDR600 reactor being considered for the Plutonium Disposition Study, which in turn is based upon the AP600 design. Release fractions are given for each of the nine fission product groups normally employed for MACCS code input [SNL 1990]. The AP600 release categories are listed in WC 1993 as follows:

OK Release associated with small leakage from an intact containment with passive containment cooling water available.

OKP Release associated with small leakage from an intact containment with passive containment cooling water not available.

CC Release associated with moderate leakage from a containment that is pressurized with noncondensible gases generated by core-concrete interaction.

CI Release associated with large leakage from a containment that is bypassed or has not been isolated.

The low release frequencies listed in Table 8-6 derive from the passive protection features that are an integral part of the AP600 reactor plant design. These low release frequencies, when combined with the smaller initial fission product inventories of the AP600 (provided in Table 8-2), contribute to calculation of a lower risk for the single small advanced reactor. For plutonium disposition at the same rate, however, two small reactors would have to be assigned in lieu of one large reactor. Thus, the risk associated with one small reactor must be doubled when the small and large reactor options are compared. 


\section{References}

CE 1994 Combustion Engineering, "Plutonium Disposition Study - Screening Study for Evaluation of the Potential for System $80+$ to Consume Excess Plutonium," April 30, 1994.

CE 1994a Combustion Engineering, "System 80+ Standard Design CESSAR Design Certification," Section 19.12.3.2, April 29, 1994.

GE 1994 General Electric, NEDO-32351, "Study of Plutonium Disposition Using the GE Advanced Boiling Water Reactor (ABWR)," April 30, 1994.

NRC 1994 U.S. Nuclear Regulatory Commission, SECY-94-300, "Proposed Issuance of Final NUREG-1465, Accident Source Terms for Light-Water Nuclear Power Plants."

SNL 1990 Sandia National Laboratories, "MELCOR Accident Consequence Code System (MACCS)," Volumes 1, 2, and 3, NUREG/CR-4691, U.S. Nuclear Regulatory Commission, Washington, DC, February 1990.

TT 1994 Tetra Tech, "Assessment of Radioactive Releases to the Environment Due to the Incorporation of Tritium Targets into an Advanced Light-Water Reactor to Produce Tritium," December 1994.

WC 1985 Westinghouse Electric Corporation, "RESAR-SP/90 Probabilistic Safety Study," Module 16, June 1985.

WC 1993 Westinghouse Electric Corporation, DOE/SF/19683-1, "PDR600 Plutonium Disposition Study," May 15, 1993.

WC 1994 Westinghouse Electric Corporation, DOE/SF/19683-5, "Plutonium Disposition Study," April 30, 1994. 
Table 8-1. Large advanced reactor initial core inventory ( $\mathrm{UO}_{2}$ fuel)

\begin{tabular}{|c|c|c|c|}
\hline Isotope & Curies & Isotope & Curies \\
\hline$\overline{A m-241}$ & $1.70 \times 10^{4}$ & Pu-238 & $6.20 \times 10^{5}$ \\
\hline $\mathrm{Ba}-139$ & $2.25 \times 10^{8}$ & Pu-239 & $5.40 \times 10^{5}$ \\
\hline $\mathrm{Ba}-140$ & $2.19 \times 10^{8}$ & $\mathrm{Pu}-240$ & $8.80 \times 10^{4}$ \\
\hline $\mathrm{Ce}-141$ & $2.09 \times 10^{8}$ & Pu-241 & $2.10 \times 10^{7}$ \\
\hline $\mathrm{Ce}-143$ & $1.97 \times 10^{8}$ & $\mathrm{Rb}-86$ & $1.80 \times 10^{5}$ \\
\hline Ce-144 & $1.57 \times 10^{8}$ & Rh-105 & $9.90 \times 10^{7}$ \\
\hline $\mathrm{Cm}-242$ & $1.30 \times 10^{7}$ & $\mathrm{Ru}-103$ & $1.70 \times 10^{8}$ \\
\hline $\mathrm{Cm}-244$ & $2.90 \times 10^{5}$ & Ru-105 & $1.20 \times 10^{8}$ \\
\hline Co-58 & - & Ru-106 & $5.90 \times 10^{7}$ \\
\hline Co-60 & - & Sb-127 & $1.09 \times 10^{7}$ \\
\hline Cs-134 & $2.10 \times 10^{?}$ & Sb-129 & $3.49 \times 10^{7}$ \\
\hline Cs-136 & $4.60 \times 10^{6}$ & Sr-89 & $1.39 \times 10^{8}$ \\
\hline Cs-137 & $1.30 \times 10^{7}$ & Sr-90 & $1.00 \times 10^{7}$ \\
\hline I-131 & $1.17 \times 10^{8}$ & Sr-91 & $1.69 \times 10^{8}$ \\
\hline $\mathrm{I}-132$ & $1.70 \times 10^{8}$ & Sr-92 & $1.79 \times 10^{8}$ \\
\hline I-133 & $2.47 \times 10^{8}$ & Tc-99M & $1.93 \times 10^{8}$ \\
\hline $\mathrm{I}-134$ & $2.73 \times 10^{8}$ & Te-127 & $1.08 \times 10^{7}$ \\
\hline I-135 & $2.30 \times 10^{8}$ & $\mathrm{Te}-127 \mathrm{M}$ & $1.42 \times 10^{6}$ \\
\hline$\overline{\mathrm{Kr}-85}$ & $1.20 \times 10^{6}$ & $\mathrm{Te}-129$ & $3.44 \times 10^{7}$ \\
\hline $\mathrm{Kr}-85 \mathrm{M}$ & $3.69 \times 10^{7}$ & $\mathrm{Te}-129 \mathrm{M}$ & $8.10 \times 10^{6}$ \\
\hline $\mathrm{Kr}-87$ & $7.23 \times 10^{7}$ & $\mathrm{Te}-131 \mathrm{M}$ & $1.63 \times 10^{7}$ \\
\hline$\overline{\mathrm{Kr}-88}$ & $1.02 \times 10^{8}$ & Te-132 & $1.67 \times 10^{8}$ \\
\hline La-140 & $2.25 \times 10^{8}$ & $\mathrm{Xe}-133$ & $2.47 \times 10^{8}$ \\
\hline La-141 & $2.06 \times 10^{8}$ & $\mathrm{Xe}-135$ & $6.33 \times 10^{7}$ \\
\hline La-142 & $2.01 \times 10^{8}$ & $Y-90$ & $1.10 \times 10^{7}$ \\
\hline Mo-99 & $2.20 \times 10^{8}$ & Y-91 & $1.75 \times 10^{8}$ \\
\hline Nb-95 & $2.19 \times 10^{8}$ & Y-92 & $1.79 \times 10^{8}$ \\
\hline Nd-147 & $8.18 \times 10^{7}$ & $Y-93$ & $2.01 \times 10^{8}$ \\
\hline Np-239 & $2.40 \times 10^{9}$ & Zr-95 & $2.18 \times 10^{8}$ \\
\hline Pr-143 & $1.93 \times 10^{8}$ & Zr-97 & $2.07 \times 10^{8}$ \\
\hline
\end{tabular}


Table 8-2. Small advanced reactor initial core inventory ( $\mathrm{UO}_{2}$ fuel)

\begin{tabular}{|c|c|c|c|}
\hline Isotope & Curies & Isotope & Curies \\
\hline Am-241 & $5.90 \times 10^{3}$ & $\mathrm{Pu}-238$ & $1.10 \times 10^{5}$ \\
\hline $\mathrm{Ba}-139$ & $1.00 \times 10^{8}$ & Pu-239 & $3.00 \times 10^{4}$ \\
\hline $\mathrm{Ba}-140$ & $9.70 \times 10^{7}$ & $\mathrm{Pu}-240$ & $3.20 \times 10^{4}$ \\
\hline $\mathrm{Ce}-141$ & $9.20 \times 10^{7}$ & $\mathrm{Pu}-241$ & $5.90 \times 10^{6}$ \\
\hline $\mathrm{Ce}-143$ & $8.60 \times 10^{7}$ & $\mathrm{Rb}-86$ & $6.20 \times 10^{4}$ \\
\hline $\mathrm{Ce}-144$ & $6.70 \times 10^{7}$ & Rh-105 & $5.70 \times 10^{7}$ \\
\hline $\mathrm{Cm}-242$ & $1.60 \times 10^{6}$ & $\mathrm{Ru}-103$ & $8.90 \times 10^{7}$ \\
\hline $\mathrm{Cm}-244$ & $8.90 \times 10^{4}$ & $\mathrm{Ru}-105$ & $5.70 \times 10^{7}$ \\
\hline $\mathrm{Co}-58$ & $4.30 \times 10$ & $4 \mathrm{Ru}-106$ & $3.00 \times 10^{7}$ \\
\hline $\mathrm{Co}-60$ & $4.00 \times 10^{4}$ & Sb-127 & $5.40 \times 10^{6}$ \\
\hline Cs-134 & $8.90 \times 10^{6}$ & Sb-129 & $1.80 \times 10^{7}$ \\
\hline Cs-136 & $2.70 \times 10^{6}$ & Sr-89 & $5.10 \times 10^{7}$ \\
\hline Cs-137 & $5.90 \times 10^{6}$ & Sr-90 & $4.30 \times 10^{6}$ \\
\hline I-131 & $5.40 \times 10^{7}$ & Sr-9l & $6.50 \times 10^{7}$ \\
\hline $\mathrm{I}-132$ & $8.10 \times 10^{7}$ & Sr-92 & $7.00 \times 10^{7}$ \\
\hline I-133 & $1.10 \times 10^{8}$ & Tc-99M & $8.90 \times 10^{7}$ \\
\hline $\mathrm{I}-134$ & $1.20 \times 10^{8}$ & $\mathrm{Te}-127$ & $5.40 \times 10^{6}$ \\
\hline $\mathrm{I}-135$ & $1.00 \times 10^{8}$ & $\mathrm{Te}-127 \mathrm{M}$ & $7.80 \times 10^{5}$ \\
\hline $\mathrm{Kr}-85$ & $5.40 \times 10^{5}$ & $\mathrm{Te}-129$ & $1.70 \times 10^{7}$ \\
\hline $\mathrm{Kr}-85 \mathrm{M}$ & $1.50 \times 10^{7}$ & $\mathrm{Te}-129 \mathrm{M}$ & $4.60 \times 10^{6}$ \\
\hline $\mathrm{Kr}-87$ & $2.70 \times 10^{7}$ & $\mathrm{Te}-131 \mathrm{M}$ & $8.40 \times 10^{6}$ \\
\hline $\mathrm{Kr}-88$ & $3.80 \times 10^{7}$ & Te-132 & $7.80 \times 10^{7}$ \\
\hline $\mathrm{La}-140$ & $1.00 \times 10^{8}$ & $\mathrm{Xe}-133$ & $1.10 \times 10^{8}$ \\
\hline La-141 & $9.20 \times 10^{7}$ & $\mathrm{Xe}-135$ & $3.50 \times 10^{7}$ \\
\hline La-142 & $8.90 \times 10^{7}$ & Y-90 & $4.60 \times 10^{6}$ \\
\hline Mo-99 & $1.00 \times 10^{8}$ & Y-91 & $6.70 \times 10^{7}$ \\
\hline $\mathrm{Nb}-95$ & $9.50 \times 10^{7}$ & $\mathrm{Y}-92$ & $7.00 \times 10^{7}$ \\
\hline Nd-147 & $3.50 \times 10^{7}$ & $\mathrm{Y}-93$ & $8.10 \times 10^{7}$ \\
\hline $\mathrm{Np}-239$ & $1.30 \times 10^{9}$ & $\mathrm{Zr}-95$ & $9.50 \times 10^{7}$ \\
\hline $\operatorname{Pr}-143$ & $8.40 \times 10^{7}$ & $\mathrm{Zr}-97$ & $9.50 \times 10^{7}$ \\
\hline
\end{tabular}


Table 8-3. Typical core inventory isotopic ratios: $\mathrm{MOX} / \mathrm{UO}_{2}$ core

\begin{tabular}{|c|c|c|c|c|c|}
\hline Isotope & $\underset{\substack{\mathrm{Ratio}_{\text {small }} \\
\mathrm{MOX} / \mathrm{UO}_{2}}}{ }$ & $\begin{array}{c}\text { MOX/UO } \\
\text { Ratiog } \\
\text { large }\end{array}$ & Isotope & $\begin{array}{c}\mathrm{MOX} / \mathrm{UO}_{2} \\
\text { Ratioli } \\
\text { small }\end{array}$ & $\begin{array}{c}\mathrm{MOX} \mathrm{MUO}_{2} \\
\text { Rarge } \\
\text { large }\end{array}$ \\
\hline $\mathrm{Am}-241$ & 4.85 & 34.71 & Pu-238 & 0.58 & 1.94 \\
\hline Ba-139 & 0.91 & 0.95 & Pu-239 & 3.03 & 5.00 \\
\hline Ba-140 & 0.93 & 0.89 & $\mathrm{Pu}-240$ & 3.75 & 4.43 \\
\hline $\mathrm{Ce}-141$ & 0.94 & 1.00 & Pu-241 & 3.49 & 1.38 \\
\hline $\mathrm{Ce}-143$ & 0.86 & 0.88 & $\mathrm{Rb}-86$ & 0.50 & 0.41 \\
\hline Ce-144 & 0.80 & 0.70 & Rh-105 & 1.43 & 1.62 \\
\hline $\mathrm{Cm}-242$ & 3.54 & 5.92 & $\mathrm{Ru}-103$ & 1.26 & 1.24 \\
\hline $\mathrm{Cm}-244$ & 1.42 & 0.83 & Ru-105 & 1.44 & 1.42 \\
\hline $\mathrm{Co}-58^{\mathrm{c}}$ & 1.00 & 1.00 & $\mathrm{Ru}-106$ & 1.76 & 1.69 \\
\hline $\mathrm{Co}-60^{\mathrm{C}}$ & 1.00 & 1.00 & Sb-127 & 1.40 & 1.67 \\
\hline Cs-134 & 0.65 & 0.52 & Sb-129 & 1.26 & 1.31 \\
\hline Cs-136 & 1.34 & 1.46 & Sr-89 & 0.57 & 0.57 \\
\hline Cs- 137 & 1.04 & 0.92 & Sr-90 & 0.50 & 0.42 \\
\hline I-131 & 1.10 & 1.10 & Sr-91 & 0.64 & 0.65 \\
\hline $\mathrm{I}-132$ & 1.04 & 1.07 & $\mathrm{Sr}-92$ & 0.70 & - \\
\hline I-133 & 1.00 & 0.95 & Tc-99M & 0.95 & 1.00 \\
\hline I-134 & 0.96 & 0.96 & $\mathrm{Te}-127$ & 1.40 & 1.69 \\
\hline I-135 & 0.92 & 1.00 & $\mathrm{Te}-127 \mathrm{M}$ & 1.54 & 1.54 \\
\hline $\mathrm{Kr}-85$ & 0.58 & 0.52 & Te-129 & 1.26 & 1.37 \\
\hline $\mathrm{Kr}-85 \mathrm{M}$ & 0.62 & 0.65 & $\mathrm{Te}-129 \mathrm{M}$ & 1.30 & 0.78 \\
\hline $\mathrm{Kr}-87$ & 0.57 & 0.59 & $\mathrm{Te}-131 \mathrm{M}$ & 1.20 & 1.20 \\
\hline $\mathrm{Kr}-88$ & 0.59 & 0.58 & $\mathrm{Te}-132$ & 1.05 & 1.07 \\
\hline La-140 & 0.93 & 0.90 & $\mathrm{Xe}-133$ & 0.98 & 0.95 \\
\hline La-141 & 0.93 & 0.94 & $\mathrm{Xe}-135$ & 1.46 & 2.89 \\
\hline La-142 & 0.90 & 0.88 & Y-90 & 0.48 & 0.38 \\
\hline Mo-99 & 0.98 & 0.95 & $Y-91$ & 0.63 & 0.61 \\
\hline $\mathrm{Nb}-95$ & 0.85 & 0.88 & $Y-92$ & 0.71 & 0.72 \\
\hline $\mathrm{Nd}-147$ & 0.97 & 0.93 & $Y-93$ & 0.78 & 0.92 \\
\hline Np-239 & 0.40 & 0.50 & $\mathrm{Zr}-95$ & 0.85 & 0.88 \\
\hline Pr-143 & 0.86 & 0.88 & $\mathrm{Zr}-97$ & 0.93 & 0.94 \\
\hline
\end{tabular}

${ }^{2}$ Ratios based on [WC 1993] Table 1.3.4-3.

${ }^{b}$ Ratios based on [GE 1994] Table 2.3-2 except for Ba-139, La-141 and -142, and Y-92 and -93 . For these isotopes, ratios were provided by GE memo XL-P2A37-95007 of February 17, 1995

${ }^{c}$ The PDR-600 design initially included the use of stainiess steel cladding, which yields ratios of approximately 50 . However, existing reactors (and the final PDR-600 design) employ Zircaloy cladding. 
Table 8-4 Estimated design basis accident releases for the large and small advanced reactor designs $\left(\mathrm{UO}_{2}\right.$ fuel)

\begin{tabular}{|c|c|c|}
\hline \multirow{2}{*}{ Isotope } & \multicolumn{2}{|c|}{$0-2$ Hour Release in Curies } \\
\hline & Small & Large \\
\hline Cs-134 & $1.5 \times 10^{1}$ & - \\
\hline Cs-136 & 4.7 & - \\
\hline Cs-137 & $1.0 \times 10^{1}$ & - \\
\hline $\mathrm{I}-130$ & 1.6 & - \\
\hline $\mathrm{I}-131$ & $1.2 \times 10^{2}$ & $2.6 \times 10^{2}$ \\
\hline $\mathrm{I}-132$ & $1.7 \times 10^{2}$ & $3.5 \times 10^{2}$ \\
\hline $\mathrm{I}-133$ & $2.2 \times 10^{2}$ & $5.4 \times 10^{2}$ \\
\hline $\mathrm{I}-134$ & $7.0 \times 10^{1}$ & $5.1 \times 10^{2}$ \\
\hline $\mathrm{I}-135$ & $1.8 \times 10^{2}$ & $5.1 \times 10^{2}$ \\
\hline $\mathrm{Kr}-83 \mathrm{M}$ & - & $3.3 \times 10^{2}$ \\
\hline $\mathrm{Kr}-85$ & 2.7 & $4.1 \times 10^{1}$ \\
\hline $\mathrm{Kr}-85 \mathrm{M}$ & $5.4 \times 10^{1}$ & $8.4 \times 10^{2}$ \\
\hline $\mathrm{Kr}-87$ & $5.5 \times 10^{1}$ & $1.2 \times 10^{3}$ \\
\hline $\mathrm{Kr}-88$ & $1.3 \times 10^{2}$ & $2.1 \times 10^{3}$ \\
\hline $\mathrm{Kr}-89$ & - & $1.8 \times 10^{2}$ \\
\hline $\mathrm{Ru}-103$ & 2.0 & - \\
\hline Ru-106 & $6.6 \times 10^{-1}$ & - \\
\hline Sr-89 & 1.2 & - \\
\hline Sr-90 & $9.9 \times 10^{-2}$ & - \\
\hline Te-129M & 2.1 & - \\
\hline $\mathrm{Te}-131 \mathrm{M}$ & 3.6 & - \\
\hline $\mathrm{Te}-132$ & $3.5 \times 10^{1}$ & - \\
\hline $\mathrm{Xe}-131 \mathrm{M}$ & 1.9 & $2.1 \times 10^{1}$ \\
\hline $\mathrm{Xe}-133$ & $5.4 \times 10^{2}$ & $7.6 \times 10^{3}$ \\
\hline $\mathrm{Xe}-133 \mathrm{M}$ & $7.8 \times 10^{1}$ & $3.0 \times 10^{2}$ \\
\hline $\mathrm{Xe}-135$ & $1.6 \times 10^{2}$ & $9.3 \times 10^{2}$ \\
\hline $\mathrm{Xe}-135 \mathrm{M}$ & 1.5 & $4.9 \times 10^{2}$ \\
\hline $\mathrm{Xe}-137$ & - & $5.1 \times 10^{2}$ \\
\hline $\mathrm{Xe}-138$ & 4.6 & $2.0 \times 10^{3}$ \\
\hline
\end{tabular}

${ }^{2}$ Entries of "- " indicate that values are not available in vendor reports. 
Table 8-5. Representative release class frequencies and release fractions for the large advanced reactor

\begin{tabular}{|c|c|c|c|c|c|c|c|c|}
\hline \multirow{2}{*}{ Chemical Species } & \multicolumn{8}{|c|}{ Release Class } \\
\hline & 1 & 2 & 3 & 4 & 5 & 6 & 7 & 8 \\
\hline $\mathrm{Xe} / \mathrm{Kr}$ & $5.0 \times 10^{-3}$ & $4.4 \times 10^{-2}$ & $5.4 \times 10^{-2}$ & & 1.0 & 1.0 & 1.0 & 1.0 \\
\hline $\mathrm{I}$ & $2.3 \times 10^{-7}$ & $2.3 \times 10^{-5}$ & $3.2 \times 10^{-4}$ & $6.4 \times 10^{-3}$ & $3.5 \times 10^{-1}$ & $1.5 \times 10^{-7}$ & $2.4 \times 10^{-2}$ & $1.1 \times 10^{-4}$ \\
\hline $\mathrm{Cs}$ & $1.9 \times 10^{-7}$ & $2.3 \times 10^{-5}$ & $1.0 \times 10^{-4}$ & $1.0 \times 10^{-4}$ & $3.2 \times 10^{-1}$ & $1.3 \times 10^{-5}$ & $1.6 \times 10^{-2}$ & $1.0 \times 10^{-3}$ \\
\hline $\mathrm{Te}$ & $9.6 \times 10^{-8}$ & & $3.6 \times 10^{-7}$ & $3.0 \times 10^{-4}$ & $1.6 \times 10^{-1}$ & & $8.3 \times 10^{-3}$ & $1.9 \times 10^{-5}$ \\
\hline $\mathrm{Sr}$ & $4.2 \times 10^{-9}$ & & $7.5 \times 10^{-9}$ & $3.1 \times 10^{-6}$ & $7.5 \times 10^{-3}$ & & $3.2 \times 10^{-4}$ & $9.0 \times 10^{-7}$ \\
\hline $\mathrm{Ru}$ & $1.4 \times 10^{-9}$ & & $1.4 \times 10^{-8}$ & $1.3 \times 10^{-5}$ & $3.5 \times 10^{-3}$ & & $1.7 \times 10^{-4}$ & $2.2 \times 10^{-7}$ \\
\hline $\mathrm{La}$ & $6.1 \times 10^{-9}$ & & $2.0 \times 10^{-8}$ & $1.5 \times 10^{-5}$ & $1.2 \times 10^{-2}$ & & $4.0 \times 10^{-4}$ & $1.0 \times 10^{-6}$ \\
\hline $\mathrm{Ce}$ & $2.6 \times 10^{-8}$ & & $1.1 \times 10^{-7}$ & $9.3 \times 10^{-5}$ & $4.2 \times 10^{-2}$ & & $2.0 \times 10^{-3}$ & $3.9 \times 10^{-6}$ \\
\hline $\mathrm{Ba}$ & $2.3 \times 10^{-8}$ & & $1.3 \times 10^{-7}$ & $1.2 \times 10^{-4}$ & $4.3 \times 10^{-2}$ & & $2.1 \times 10^{-3}$ & $3.5 \times 10^{-6}$ \\
\hline Frequency/yr. & $1.7 \times 10^{-6}$ & $1.3 \times 10^{-7}$ & $1.2 \times 10^{-7}$ & $2.6 \times 10^{-8}$ & $2.2 \times 10^{-8}$ & $2.1 \times 10^{-8}$ & $1.8 \times 10^{-8}$ & $1.1 \times 10^{-8}$ \\
\hline
\end{tabular}

Source: See text. 
Table 8-6. Release class frequencies and release fractions for the small advanced reactor

\begin{tabular}{|c|c|c|c|c|}
\hline \multirow{2}{*}{ Chemical Species } & \multicolumn{4}{|c|}{ Release Class } \\
\cline { 2 - 5 } & OK & OKP & CC & CI \\
\hline $\mathrm{Xe} / \mathrm{Kr}$ & $4.2 \times 10^{-5}$ & $1.0 \times 10^{-4}$ & $6.4 \times 10^{-5}$ & $3.4 \times 10^{-1}$ \\
\hline $\mathrm{I}$ & $5.6 \times 10^{-7}$ & $2.0 \times 10^{-6}$ & $7.9 \times 10^{-7}$ & $3.7 \times 10^{-2}$ \\
\hline $\mathrm{Cs}$ & $5.8 \times 10^{-7}$ & $2.0 \times 10^{-6}$ & $9.0 \times 10^{-7}$ & $3.7 \times 10^{-2}$ \\
\hline $\mathrm{Te}$ & $1.0 \times 10^{-6}$ & $4.8 \times 10^{-6}$ & $1.1 \times 10^{-6}$ & $1.1 \times 10^{-3}$ \\
\hline $\mathrm{Sr}$ & $3.2 \times 10^{-8}$ & $8.0 \times 10^{-8}$ & $4.9 \times 10^{-8}$ & $6.7 \times 10^{-5}$ \\
\hline $\mathrm{Ru}$ & $5.6 \times 10^{-7}$ & $9.6 \times 10^{-7}$ & $6.5 \times 10^{-7}$ & $1.4 \times 10^{-3}$ \\
\hline $\mathrm{La}$ & $2.0 \times 10^{-8}$ & $5.5 \times 10^{-8}$ & $3.1 \times 10^{-8}$ & $2.0 \times 10^{-5}$ \\
\hline $\mathrm{Ce}$ & $5.9 \times 10^{-8}$ & $1.6 \times 10^{-7}$ & $1.1 \times 10^{-7}$ & $2.8 \times 10^{-5}$ \\
\hline $\mathrm{Ba}$ & $2.9 \times 10^{-7}$ & $6.5 \times 10^{-7}$ & $4.2 \times 10^{-7}$ & $4.8 \times 10^{-4}$ \\
\hline Frequency/yr. & $2.5 \times 10^{-7}$ & $5.6 \times 10^{-8}$ & $7.6 \times 10^{-10}$ & $2.0 \times 10^{-8}$ \\
\hline
\end{tabular}

Source: Assessment of Radioactive Releases to the Environment Due to the Incorporation of Tritium Targets into an Advanced Light Water Reactor to Produce Tritium, Table 4.2, Tetra Tech, Inc., December 1994. 


\subsection{TRANSPORTATION}

For the purpose of considering environmental impact, it is assumed in this data report that the MOX fuel fabrication facility is not co-located with the reactors. Therefore, transportation of plutonium recovered from weapons as feed material to the MOX fuel fabrication facility is not covered in this data report. Movements of the fuel from receipt on site to removal from the spent fuel storage facility is discussed in Section 9.1, "Intrasite Transportation". Transportation of fresh fuel assemblies to the reactor site and removal of spent fuel from the reactor site is discussed in Section 9.2, "Intersite Transportation".

\subsection{Intrasite Transportation}

The intrasite transportation system includes all the elements necessary to transport the fresh fuel from the point of receipt at the reactor site to the interim storage for the fresh fuel. The fuel will be transported from the interim storage facility to be placed in the core of the reactor. After the fuel has reached the specified burn-up, the spent fuel will be transported to a spent fuel storage pond and cooled for approximately 10 years. Thus, the intrasite transport of materials will be limited to movements of fresh and spent fuel assemblies. The transport of the fuel assemblies will be by bridge cranes and special fuel handling vehicles used for intrasite transport of fuel at conventional $\mathrm{UO}_{2}$-fueled reactor plants. It is anticipated that no special measures will be required for intrasite transport of $\mathrm{MOX}$ fuel (i.e., compared to equivalent transport of $\mathrm{UO}_{2}$ fuel), unless special administrative requirements are imposed (e.g., for purposes of enhancing safeguards and security). If, for reasons of safeguards and security, it is determined that fresh fuel is to be shipped to the reactor site in Safe-Secure Transport (SST) vehicles, it will be necessary to provide special fuel receival facilities which may affect intrasite transportation of fresh fuel.

\subsection{Intersite Transportation}

The intersite transportation supporting the reactor-based disposition of excess weapons plutonium comprises two elements: (1) transportation of the fresh MOX fuel from the fuel fabrication facility to the reactor, ${ }^{1}$ and (2) transportation of the spent nuclear fuel (SNF) from the onsite storage ponds to a DOE repository (or other long-term storage facility). To the extent that both the fuel fabrication facility and the DOE repository are located away from the reactor complex, the transportation of both fresh fuel and spent fuel will use public highways. Thus the shipments will comply with U.S. Department of Transportation (DOT) regulations, specifically Title 49 of the Code of Federal Regulations Part 173 (49CFR173), Subpart I, which specifies the general requirements for shipments and packages of radioactive materials.

Each of the MOX fresh fuel pins contains about $100 \mathrm{~g}$ of Pu-239 which is a Type B quantity of radioactive material as defined by 49 CFR 173.408 (dd). Thus the packaging and transportation of the MOX fresh fuel assemblies, as well as that of the spent fuel assemblies, must comply with

\footnotetext{
${ }^{1}$ For purposes of this data report, it has been assumed that the reactor facility and the fuel fabrication facility are not located on a common site.
} 
10CFR71. However, the package design(s) for transportation of the MOX fresh fuel may be different than for the spent fuel. The presence of fission products with their assorted $\alpha$-decay energies will increase the shielding required for the spent fuel assemblies relative to the fresh fuel assemblies.

Intersite transportation data for the large ALWR is tabulated in Table 9-1a for both PWR and BWR plants. Equivalent data for a small ALWR is tabulated in Table 9-1b, based on information for a Westinghouse PDR-600 pressurized water reactor plant.

\subsubsection{Incoming Material}

The incoming material to the ALWR facility will consist of the MOX fuel assemblies for the reactor. The fuel assemblies will be similar to those for a uranium-fueled reactor using a number of fuel pins arranged in a square matrix. The chemical composition of the fuel will be a mixture of uranium dioxide and plutonium dioxide with, in some cases, a small amount of a rare earth oxide used as a burnable poison.

Currently certified packaging does not exist for the Type B MOX fuel assemblies. Fissile material Type A packaging is used to ship fresh fuel using low-enrichments of U-235 (i.e., conventional power reactor fuel). A fissile material package must endure the hypothetical accident sequence of 10CFR71.73 to demonstrate that the package will remain sub-critical in accordance with 10CFR71.55. No containment requirement exists for a Type A packaging. The primary issue for the Type B packaging for MOX fresh fuel assemblies will be the containment of the contents as prescribed by 10CFR71.51. The shielding of the fresh fuel necessary to meet the regulatory standards of 10CFR71.47 should be, with the exception of the neutron production from the $\alpha, \mathrm{n}$ interactions in the oxide, similar to that of a similarly enriched uranium fuel assembly. The criticality issues associated with the plutonium-containing fresh fuel should also be similar to those for a similarly enriched uranium fuel. Thus, to the extent that the criticality and shielding issues associated with the plutonium-containing fresh fuel are not much different than for the low-enriched uranium fuel for LWRs, the packaging design need only address the normal conditions of transport in addition to the containment issue associated with the sequence of hypothetical accident conditions. The containment issues associated with the sequence of the hypothetical accidents may be satisfied by the modification of the Type A packaging for the lowenriched uranium fuel assemblies by encasing the packaging with stainless steel. The packaging design for the plutonium-containing fresh fuel may be different from the low-enriched uranium fresh fuel packages in that the decay heat from the uranium packages is essentially zero while that of the plutonium-containing fuel assemblies is about 2 watts per kilogram of plutonium. Depending on the type of fuel assembly (i.e., PWR or BWR) and enrichment of plutonium, the decay heat may approach 100 watts per assembly.

While a Type B package certified for shipping MOX fresh fuel does not yet exist, the reactor vendors participating in the DOE Plutonium Disposition Study (DOE-PDS) all postulated two fresh fuel assembles per package. Based on the fuel assembly replacement rate for each type of reactor, the average number of packages shipped per year is given in Tables 9-1a and 9-1b for the large ALWR and the small ALWR, respectively. 
The MOX fresh fuel assemblies will need to satisfy the safeguards and security requirements of 10CFR73.25 and 73.26. The MOX fresh fuel assemblies for the ABWR are specified by the vendor to be shipped in a Safe-Secure Transport (SST) which satisfies, in part, the requirements of 10CFR73. For an assumed SST load limit of 4.6 tonnes, each shipment is limited to five packages each containing two fuel assemblies (i.e., for a total of ten assemblies). The PWR vendors assumed that each shipment of PWR fuel assemblies consisted of six packages each containing two fuel assemblies (i.e., for a total of 12 assemblies per shipment). The annual shipment rate and number of shipments over the life of the project for the various reactor options are given in Tables 9-1a and 9-1b.

\subsubsection{Outgoing Material}

The majority of the activity shipped from the reactor facility to a repository will consist of spent fuel assemblies. other activity includes low-level waste (LLW) sent to a LLW facility and TRU waste that will be sent to the Waste Isolation Pilot Plant (WIPP). This activity has not been sufficiently quantified by the vendors to make projects of the transportation requirements.

The spent fuel assemblies will contain plutonium and uranium dioxide as well as fission products. The spent fuel will be allowed to cool for a minimum of 10 years prior to shipment to a repository. The spent fuel packages must conform to the requirements of 10CFR71. NRCcertified packages exist for the shipment of spent fuel. An example of an NRC-certified package for spent fuel shipments is described by the Certificate of Compliance 9225 . The mass of this package is about 23.3 tonnes with 1.8 tonnes of content including the fuel basket. The package contents include either one PWR spent fuel assembly or two BWR spent fuel assemblies. The maximum decay heat is not to exceed $2.5 \mathrm{~kW}$. Typically only one cask is transported per tractortrailer combination.

The transportation packages for the spent fuel from plutonium-containing fresh fuel can use the same packages as for the spent fuel from uranium reactors provided that the initial plutonium loading (on a per-atom basis) is identical to that for the U-235 low-enriched fuel, and additionally that the maximum average burnup is identical for both the plutonium-containing fresh fuel as for the enriched uranium fuel.

In the DOE-PDS, the System $80+$ vendor assumed a package that contained a single fuel assembly. The other vendors assumed that a Multi-Purpose Container (MPC) truck cask of legal weight will be available for spent fuel transport. This cask, currently unlicensed, will weigh about 23 tonnes with a capacity of 4 PWR or 9 BWR assemblies.

The spent fuel shipments will be governed by 10CFR73.37 for safeguards and security as well as by the DOT and NRC regulations.

The spent fuel shipment schedules will be less demanding than the delivery schedules for fresh fuel. Thus the average annual shipment rate is relatively unimportant until the spent fuel storage facility at the reactor site is filled, at which time the delivery schedule will reflect the rate of removal of assemblies from the core. The number of spent fuel shipments for the various reactor types is given in Tables 9-1 and 9-2, respectively, for the large ALWR and small ALWR. 
Table 9-1. Intersite Transportation Data - Large ALWR

\begin{tabular}{|c|c|c|c|}
\hline & \multicolumn{3}{|c|}{ Output (10-year cooldown) } \\
\hline & System $80+$ & PDR 1400 & ABWR \\
\hline \multicolumn{4}{|l|}{ Transported Materials } \\
\hline Type & $\begin{array}{l}\text { Spent Fuel } \\
\text { Assemblies }\end{array}$ & $\begin{array}{l}\text { Spent Fuel } \\
\text { Assemblies }\end{array}$ & $\begin{array}{l}\text { Spent Fuel } \\
\text { Assemblies }\end{array}$ \\
\hline Physical Form & $16 \times 16$ & $17 \times 17$ & $8 \times 8$ \\
\hline $\begin{array}{l}\text { Chemical Composition } \\
\text { (FP = fission products) }\end{array}$ & $\begin{array}{l}\text { Zircaloy IV } \\
\text { PuO }_{2}+\mathrm{FP}\end{array}$ & $\begin{array}{l}\text { Zircaloy IV } \\
\mathrm{PuO}_{2}+\mathrm{FP}\end{array}$ & $\begin{array}{l}\text { Zircaloy IV } \\
\mathrm{PuO}_{2}+\mathrm{FP}\end{array}$ \\
\hline \multicolumn{4}{|l|}{ Packaging } \\
\hline Type & $B$ & $B$ & $B$ \\
\hline Certified by & (see text) & (see text) & (see text) \\
\hline \multicolumn{4}{|l|}{ Identifier } \\
\hline Container Weight $(\mathrm{kg})$ & 23000 (est.) & 23000 (est.) & 23000 (est.) \\
\hline Material Weight $(\mathrm{kg})$ & 410 & 522 & 303 \\
\hline Isotopic Content (\%) & $\begin{array}{l}0.02 \% \%^{238} \mathrm{Pu} \\
3.12 \%{ }^{239} \mathrm{Pu} \\
1.21 \%{ }^{240} \mathrm{Pu} \\
0.43 \%{ }^{241} \mathrm{Pu} \\
0.10 \%{ }^{242} \mathrm{Pu}\end{array}$ & $\begin{array}{l}0.005 \% \%^{238} \mathrm{Pu} \\
3: 15 \%{ }^{239} \mathrm{Pu} \\
1.23 \%{ }^{240} \mathrm{Pu} \\
0.37 \%^{241} \mathrm{Pu} \\
0.09 \%^{242} \mathrm{Pu}\end{array}$ & $\begin{array}{l}0.06 \%{ }^{238} \mathrm{Pu} \\
1.70 \%{ }^{239} \mathrm{Pu} \\
1.11 \%{ }^{240} \mathrm{Pu} \\
0.26 \%{ }^{241} \mathrm{Pu} \\
0.15 \%{ }^{242} \mathrm{Pu}\end{array}$ \\
\hline \multicolumn{4}{|l|}{ Average Shipping Volume } \\
\hline Quantity/year (assemblies) & 121 & 286 & 240 \\
\hline \multicolumn{4}{|l|}{$\begin{array}{l}\text { Average number of packages } \\
\text { shipped per year }\end{array}$} \\
\hline $\begin{array}{l}\text { Estimated number of packages } \\
\text { shipped over disposition } \\
\text { mission }\end{array}$ & 1928 & 450 & 606 \\
\hline $\begin{array}{l}\text { Average number of packages } \\
\text { per shipment }\end{array}$ & 1 & 4 & 9 \\
\hline \multicolumn{4}{|l|}{ Number of shipments/year } \\
\hline $\begin{array}{l}\text { Number of shipments over } \\
\text { disposition mission }\end{array}$ & 1928 & 450 & 606 \\
\hline \multicolumn{4}{|l|}{ Routing } \\
\hline Destination Facility & Repository & Repository & Repository \\
\hline
\end{tabular}


Table 9-2. Intersite Transportation Data - Small ALWR

\begin{tabular}{|c|c|c|}
\hline & $\begin{array}{l}\text { PDR-600 } \\
\text { Input }\end{array}$ & $\begin{array}{l}\text { PDR } 600 \\
\text { Output }\end{array}$ \\
\hline \multicolumn{3}{|l|}{ Transported Materials } \\
\hline Type & $\begin{array}{l}\text { Fresh Fuel } \\
\text { Assemblies }\end{array}$ & $\begin{array}{l}\text { Spent Fuel } \\
\text { Assemblies }\end{array}$ \\
\hline Physical Form & $17 \times 17$ & $17 \times 17$ \\
\hline $\begin{array}{l}\text { Chemical Composition } \\
\text { (FP = fission products) }\end{array}$ & $\begin{array}{l}\text { Type } 304 \mathrm{SS} \\
\mathrm{UO}_{2}-\mathrm{PuO}_{2}\end{array}$ & $\begin{array}{l}\text { Type } 304 \text { SS } \\
\mathrm{UO}_{2}-\mathrm{PuO}_{2}+\mathrm{FP}\end{array}$ \\
\hline \multicolumn{3}{|l|}{ Packaging } \\
\hline Type & $B$ & $B$ \\
\hline Certified by & & (see text) \\
\hline \multicolumn{3}{|l|}{ Identifier } \\
\hline Container Weight (kg) & & 23000 (est,) \\
\hline Material Weight $(\mathrm{kg})$ & 1044 & 522 \\
\hline Isotopic Content (\%) & $\begin{array}{l}6.18 \%{ }^{239} \mathrm{Pu} \\
0.39 \%{ }^{240} \mathrm{Pu} \\
0.03 \%{ }^{241} \mathrm{Pu} \\
0.001 \%{ }^{242} \mathrm{Pu}\end{array}$ & $\begin{array}{l}0.005 \%{ }^{238} \mathrm{Pu} \\
3.21 \%{ }^{239} \mathrm{Pu} \\
1.25 \%{ }^{240} \mathrm{Pu} \\
0.38 \%{ }^{241} \mathrm{Pu} \\
0.09 \%{ }^{242} \mathrm{Pu}\end{array}$ \\
\hline \multicolumn{3}{|l|}{ Average Shipping Volume } \\
\hline Quantity/year (assemblies) & 286 & 286 \\
\hline $\begin{array}{l}\text { Average number of packages } \\
\text { shipped per year }\end{array}$ & 146 & \\
\hline $\begin{array}{l}\text { Estimated number of packages } \\
\text { shipped over disposition } \\
\text { mission }\end{array}$ & 846 & \\
\hline $\begin{array}{l}\text { Average number of packages } \\
\text { per shipment }\end{array}$ & 6 & 4 \\
\hline Number of shipments/year & 24 & \\
\hline $\begin{array}{l}\text { Number of shipments over } \\
\text { disposition mission }\end{array}$ & 141 & 423 \\
\hline \multicolumn{3}{|l|}{ Routing } \\
\hline Destination Facility & N/A & Repository \\
\hline
\end{tabular}




\subsection{REFERENCES}

References are provided at the end of each section. 


\subsection{GLOSSARY}

ABB Asea Brown Boveri Corporation

ABWR Advanced Boiling Water Reactor

AEC U.S. Atomic Energy Commission

ALARA As Low As Reasonably Achievable

ATWS Anticipated Transient Without Scram

$\mathrm{ACI} \quad$ American Concrete Institute

AEA Atomic Energy Act of 1954

ANS American Nuclear Society

ANSI American National Standards Institute

APWR Advanced Pressurized Water Reactor

ASCE American Society of Civil Engineers

ASHRAE American Society of Heating, Refrigerating, and Air Conditioning Engineers

BWR Boiling Water Reactor

CANDU Canadian Deuterium-Uranium reactor

$\mathrm{CE} \quad$ Combustion Engineering Corporation (ABB-Combustion Engineering)

CFR U.S. Code of Federal Regulations

CVCS Chemical and Volume Control System

DAW - Dry Active Wastes

DBA Design Basis Accident

DBE Design Basis Earthquake

DBFL Design Basis Flood

DBT Design Basis Tornado

DBW Design Basis Wind

DOE Department of Energy

DOE-MD Office of Fisile Material Disposition (DOE)

DOE-NE Office of Nuclear Energy (DOE)

DOE-STD DOE Standard

EEO Equal Employment Opportunity 


\begin{tabular}{|c|c|}
\hline EIS & Environmental Impact Statement \\
\hline EPRI & Electric Power Research Institute \\
\hline ES\&H & Environment, Safety, and Health \\
\hline ESF & Engineered Safety Feature \\
\hline FMDP & Fissile Materials Disposition Program \\
\hline FP & Fission Products \\
\hline GDC & General Design Criterion (or Criteria) \\
\hline GE & General Electric Company \\
\hline HEPA & High-Efficiency Particulate Air (filter) \\
\hline $\mathrm{HC}$ & Hazard Category \\
\hline HEU & Highly-Enriched Uranium (typically over $20 \%$ ) \\
\hline $\mathrm{HM}$ & Heavy Metal (refers to actinide metals) \\
\hline HLW & High-Level Waste \\
\hline HVAC & Heating, Ventilating, and Air Conditioning \\
\hline IAEA & International Atomic Energy Agency \\
\hline IEEE & Institute of Electrical and Electronic Engineers \\
\hline LEU & Low-Enriched Uranium (typically under 4\%) \\
\hline LLNL & Lawrence Livermore National Laboratory \\
\hline LLW & Low-Level Waste \\
\hline LWR & Light Water Reactor \\
\hline LOCA & Loss-of-Coolant Accident \\
\hline MOX & Mixed Oxide (normally refers to dioxides of uranium and plutonium) \\
\hline MPC & Multi-Purpose Container \\
\hline NEPA & National Environmental Protection Act \\
\hline NESHAP & National Emission Standards for Hazardous Air Pollutants \\
\hline NFPA & National Fire Protection Association \\
\hline NHPA & National Historic Preservation Act \\
\hline NPDES & National Pollutant .Discharge Elimination System \\
\hline $\mathrm{NPH}$ & Natural Phenomena Hazard(s) \\
\hline NRC & Nuclear Regulatory Commission \\
\hline
\end{tabular}


ORE Occupational Radiation Exposure

ORNL Oak Ridge National Laboratory

PEIS Programmatic Environmental Impact Staterment

PDR Plutonium Disposition Reactor

PDS Plutonium Disposition Study (DOE-NE)

PG Performance Goal

PRA Probabilistic Risk Assessment

PSD Prevention of Significant Deterioration (of Air Quality)

PWR Pressurized Water Reactor

QA Quality Assurance

RCRA Resource Conservation and Recovery Act

S\&S Safeguards and Security

SAR Safety Analysis Report

SBWR Simplified Boiling Water Reactor

SFM Surplus Fissile Material

SNF Spent Nuclear Fuel

SNL Sandia National Laboratory

SNM Special Nuclesr Material

SSAR Standard Safety Analysis Report

SSC's Structures, Systems, and Components

SST Safe-Secure Transport

TDS Total Dissolved Solids

TRU Transuranic (e.g., wastes)

TSCA Toxic Substances Control Act

TT Tetra Tech, Inc.

TVA Tennessee Valley Authority

UBC Uniform Building Code

WIPP Waste Isolation Pilot Plant 